\title{
ESTRESSE HÍDRICO E CARACTERÍSTICAS AGRONÔMICAS DE MATERIAIS SUPERPRECOCES DE MILHO (Zea mays L.)
}

\author{
OSVALDO JOSÉ DE OLIVEIRA \\ Engenheiro Agrônomo
}

Orientador: Prof. Dr. MARCOS VINÍCIUS FOLEGATTI

Tese apresentada à Escola Superior de Agricultura "Luiz de Queiroz", Universidade de São Paulo, para obtenção do título de Doutor em Agronomia, Área de Concentração: Irrigação e Drenagem.

PIRACICABA

Estado de São Paulo - Brasil

Fevereiro - 2000 


\section{ERRATA}

\begin{tabular}{|c|c|c|}
\hline Página & Onde se lê & Leia-se \\
\hline 29 & $\begin{array}{l}\ldots . \text { "identificassem consumo de } \\
\text { agua na parcela de controle"... }\end{array}$ & $\begin{array}{l}\text {... "identificassem consumo de água } \\
\text { próximo à } \theta_{\text {crítico }} \text { na parcela de } \\
\text { controle"... }\end{array}$ \\
\hline $\begin{array}{c}38 \\
\text { (Tabela 5) }\end{array}$ & "duração média das fases". & $\begin{array}{l}\text {..."duração média acumulada das } \\
\text { fases".. }\end{array}$ \\
\hline $\begin{array}{c}39 \\
\text { (Figura 3, } \\
\text { gráfico inferior } \\
\text { a direita) } \\
\end{array}$ & $\begin{array}{l}\ldots . \text { pressão de vapor d'água } \\
(\mathrm{KPa})^{\prime \prime} . . .\end{array}$ & $\begin{array}{l}\text {..."déficit de pressão de vapor d 'água } \\
(\text { KPa })^{\prime \prime . . . ~}\end{array}$ \\
\hline $\begin{array}{c}44 \\
\left(2^{\circ} \text { parágr }\right. \\
\end{array}$ & ."observadas em 15/03".. & adas em 15/08". \\
\hline 55 & $\begin{array}{llr}\text {..de } & \text { determinação }\left(R^{2}\right): \\
0,9624 ; \quad 0,8325 ; \quad 0,7546 \quad e \\
0,7766: \ldots\end{array}$ & $\begin{array}{l}\ldots \text {."de determinação }\left(R^{2}\right) \text { : } \\
0,8442 ; 0,9553 \text { e } 0,8325^{\prime \prime} \ldots\end{array}$ \\
\hline 55 & $\begin{array}{l}\text {..."contrastando, o material } A G \text { - } \\
9014 " \ldots\end{array}$ & "contrastando, o material AG-9012"... \\
\hline 55 & $\begin{array}{l}\text {..."de agua aplicada foi } \\
\text { observada no material C-806"... }\end{array}$ & $\begin{array}{l}\text {..."de água aplicada foram observados } \\
\text { nos materiais } A G-9014 \text { e } C-806 " . .\end{array}$ \\
\hline 57 & $\begin{array}{l}\text {..."déficit de evapotranspiração } \\
\text { relativa }\left[1-\left(\text { ETr }_{(i j)} . \text { ETm }{ }_{(i j)}\right)^{-1}\right] \\
\text { déficit de rendimento relativo } \\
{\left[1-\left(Y r_{(i j)} . Y_{(i i)}\right)^{-1}\right) \text { possibilitou"... }}\end{array}$ & $\begin{array}{l}\text {..."déficit de rendimento relativo }[1- \\
\left.\left(\text { Yr }_{(i j) .} \text { Ym }_{(i j)}\right)^{-1}\right) \text { e déficit } \\
\text { evapotranspiração de relativa } \\
\left.\left(\text { ETr }_{(i j) .} \text { ETm }_{(i j)}\right)^{-1}\right] \text { possibilitou".. }\end{array}$ \\
\hline
\end{tabular}




\section{Dados Internacionais de Catalogação na Publicação (CIP) DIVISÃO DE BIBLIOTECA E DOCUMENTAÇĀO - Campus "Luiz de Queiroz"/USP}

\section{Oliveira, Osvaldo José de}

Estresse hidrico e características agronômicas de materiais superprecoces de milho (Zea mays L.) / Osvaldo José de Oliveira. - - Piracicaba, 2000.

$89 \mathrm{p}$.

Tese (doutorado) - Escola Superior de Agricultura Luiz de Queiroz, 2000.

Bibliografia.

1. Balanço hídrico 2. Característica agronômica 3. Estresse hidrico 4. Interaçăo genótipo-ambiente 5. Irrigação por aspersão 6. Milho 7. Safrinha 1. Titulo

CDD 633.15

"Pernitida a cópia total ou parcial deste documento, desde que citada a fonte - $\mathbf{O}$ autor" 
"Aos esfarrapados do mundo e aos que neles se descobrem e, assim descobrindo-se, com eles sofrem, mas sobretudo, com eles lutam

Paulo Freire

Aos meus queridos Pais Abilio José de Oliveira (in memorian) Anastácia Dias de Oliveira (in memorian)

Dedico 


\section{AGRADECIMENTOS}

A Deus, pela constante presença possibilitando perseverança junto aos desafios impostos na luta pela vida;

À minha esposa Rozimeiry, pelo apoio, compreensão e companheirismo;

À ESCOLA AGROTÉCNICA FEDERAL DE CUIABÁ-MT pela possibilidade de realização deste curso e aos companheiros Docentes pela amizade e compreensão;

À ESCOLA SUPERIOR DE AGRICULTURA “LUIZ DE QUEIROZ”, através do DEPARTAMENTO DE ENGENHARIA RURAL e DEPARTAMENTO DE FÍSICA E METEOROLOGIA pela qualidade e eficácia das aulas oportunizadas durante o desenvolvimento do curso;

Aos companheiros de curso, estudantes e funcionários do DEPARTAMENTO DE ENGENHARIA RURAL da ESALQ-USP;

Aos professores da ESALQ-USP, pelo exemplo de dedicação e compromisso com a ciência a serviço da agricultura, em especial ao Professor MARCOS VINÍCIUS FOLEGATTI, pela orientação, amizade, compreensão, dinamismo e constante positivismo frente a cada tarefa, bem como pelos esforços empreendidos na busca de qualidade junto ao curso de pós-graduação em Irrigação e Drenagem da ESALQ-USP, e ao Professor ANTONIO ROBERTO PEREIRA, pela oportunidade da amizade, pelo exemplo de sabedoria e pelos relevantes serviços prestados ao meio científico no campo da Agrometeorologia;

A CAPES pela concessão de auxilio financeiro na forma de bolsa de estudo;

Às empresas CARGILL, AGROCERES e ZENECA pela concessão do banco de sementes e informações complementares;

A Bibliotecária LIGIANA CLEMENTE DO CARMO, pela revisão das referências bibliográficas;

Ao Professor WILLIAN DE PAULA, pelas sugestões nas correções ortográficas, e a todos aqueles que colaboraram na realização deste trabalho. 


\section{SUMÁRIO}

Página

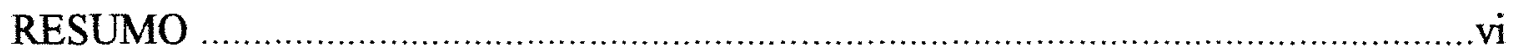

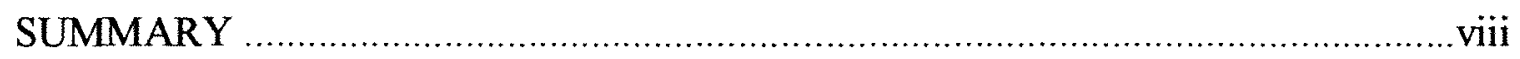

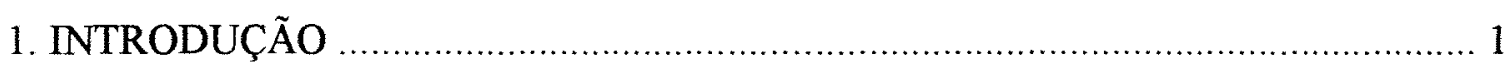

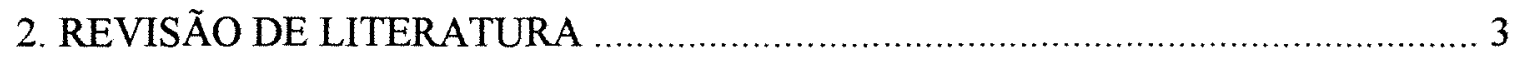

2.1. Milho (Zea mays L.), situacão atual ...................................................... 3

2.2. Milho (Zea mays L.), em cultivo extemporâneo (safrinha) ............................. 10

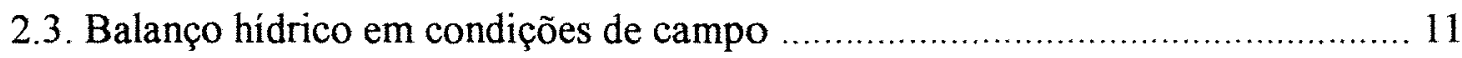

2.4. Aspectos morfo-fisiológicos na produção de milho ................................... 14

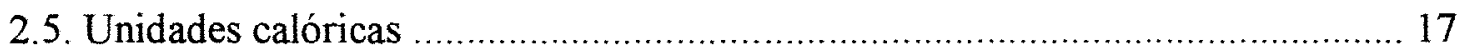

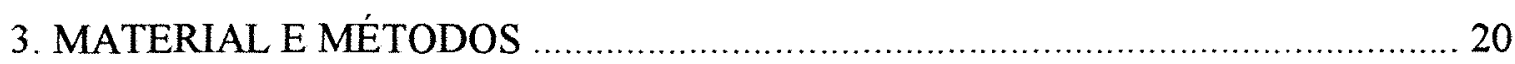

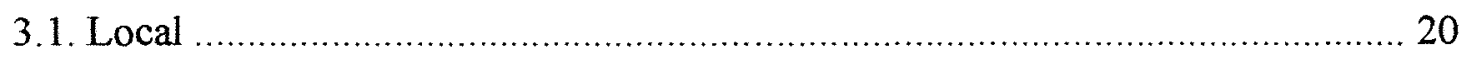

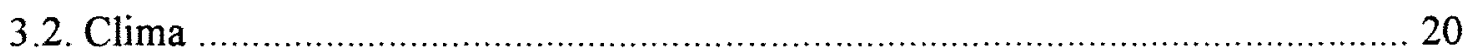

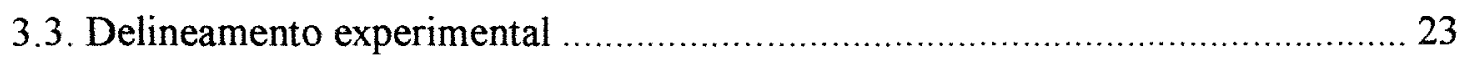

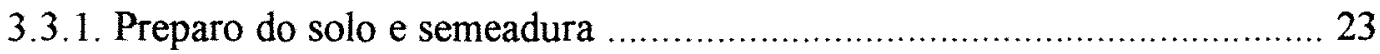

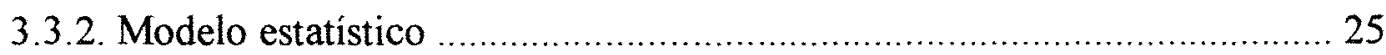

3.3.3. Sistema de aplicação de água ................................................... 26

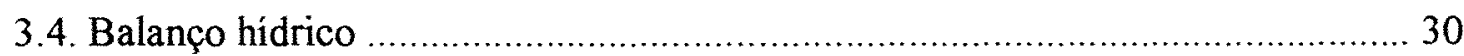

3.5. Graus-dia e parâmetros de desenvolvimento .......................................... 33

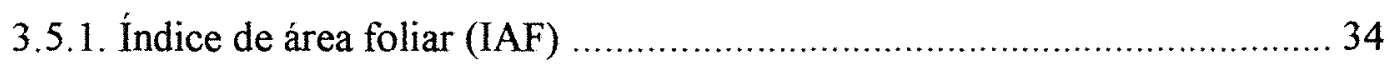

3.5.2. Intervalo de florescimento masculino e feminino (IFMF) ..................... 34

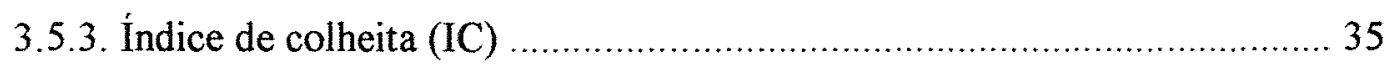

3.5.4. Coeficiente de resposta ao estresse hidrico $(\mathrm{ky})$............................ 35

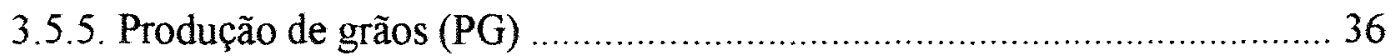

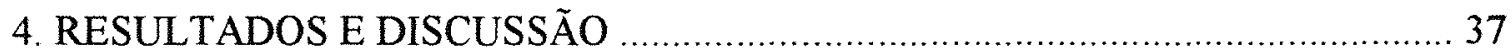

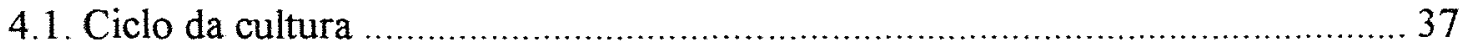

4.2. Manejo da irrigação .................................................................. 40 


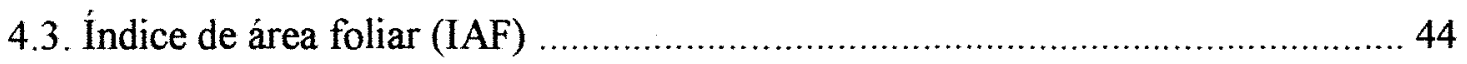

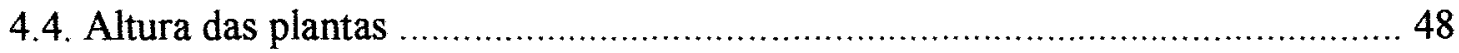

4.5. Intervalo entre florescimento masculino e feminino (IFMF) ……................5 50

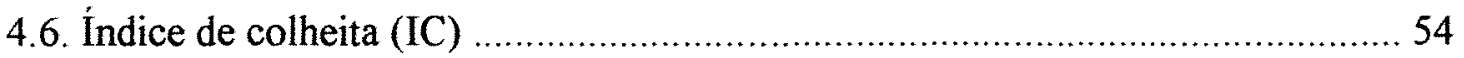

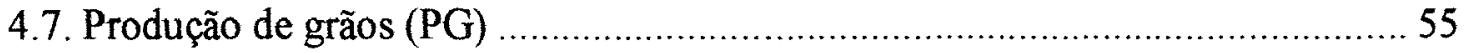

4.8. Fator de resposta ao estresse hídrico (ky) .................................................. 57

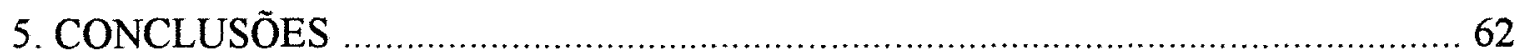

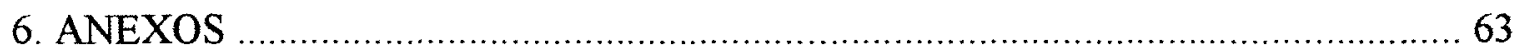

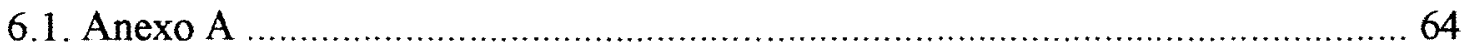

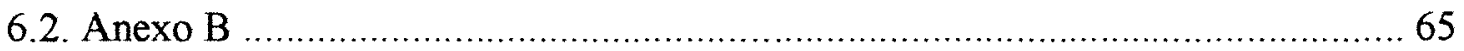

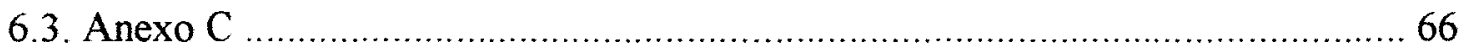

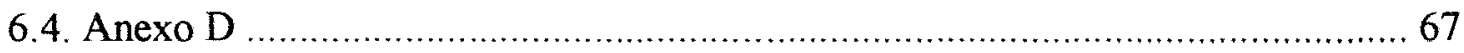

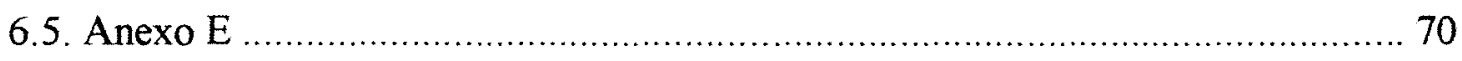

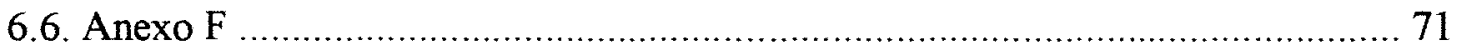

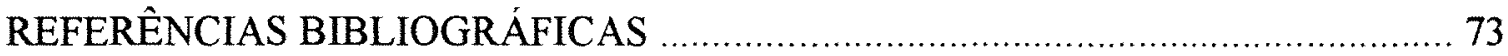




\title{
ESTRESSE HÍDRICO E CARACTERÍSTICAS AGRONÔMICAS DE MATERIAIS SUPERPRECOCES DE MILHO (Zea mays L.)
}

\author{
Autor: OSVALDO JOSÉ DE OLIVEIRA \\ Orientador: Prof. MARCOS VINÍCIUS FOLEGATTI
}

\section{RESUMO}

Este trabalho teve como finalidade investigar respostas de caracteristicas agronômicas nos materiais de milho; Cargill - 806, Agroceres - 9012, Agroceres - 9014 e Zeneca - 8392, ciclo superprecoce, com interação genótipo-ambiente às condições locais do experimento, submetidos a oito níveis de estresse hídrico.

Utilizou-se a técnica da aspersão em linha, delineamento experimental em blocos casualizados com parcelas subdivididas em cinco repetições. $O$ controle da irrigação foi com base em tensiômetros e elementos meteorológicos (temperatura do ar e evaporimetro de Piché). Efetuou-se a aplicação das lâminas de água quando um dos controles acusasse o limite da capacidade de água disponivel às plantas.

Observou-se que os materiais Zeneca - 8392 e Cargill - 806 suplantaram os demais em relação ao índice totalizado de área foliar (IAF). Não houve diferença estatística entre materiais em relação à altura das plantas. Os menores intervalos entre florescimento masculino e feminino (IFMF) foram observados em Zeneca - 8392 e Cargill - 806, enquanto que Agroceres 9012 e Agroceres - 9014 apresentaram maiores IFMF. $O$ índice de colheita (IC) diferiu estatisticamente ente materiais. Cargill-806 apresentou IC mais elevado seguido dos materiais Agroceres 9014 e Zeneca - 8392. O 
menor IC observado foi no material Agroceres - 9012 e a melhor relação entre rendimento de grãos e NEH foi observado no material Cargill - 806.

Em relação ao coeficiente de resposta ao estresse hídrico (ky), o material Zeneca - 8392 mostrou-se mais sensivel. O menor valor de ky foi observado no material Agroceres-9012.

O índice de área foliar (IAF), rendimento de grãos $\left(\mathrm{kg} \cdot \mathrm{ha}^{-1}\right)$, e eficiência no uso da água (e.u.a.), mostraram proporcionalidades decrescentes frente aos níveis de estresse hídrico impostos, apresentando intensidades de respostas diferenciadas entre materiais de milho.

Pelos índices avaliados, observou-se que Agroceres - 9014 e Zeneca - 8392 são os de maior sensibilidade ao estresse hídrico, e Cargill - 806 e Agroceres - 9012 são os de maior estabilidade frente às condições de estresse hídrico às quais foram submetidos, oferecendo condição de menor risco para cultivo extemporâneo. 


\title{
WATER STRESS AND AGRONOMICAL CHARACTERISTICS OF PRECOCIOUS CORN (Zea mays L.) MATERIALS
}

\author{
Author: OSVALDO JOSÉ DE OLIVEIRA \\ Advisor: Prof. MARCOS VINICIUS FOLEGATTI
}

\section{SUMMARY}

This study aimed at investigating characteristic responses in corn materials; Cargill - 806, Agroceres - 9012, Agroceres - 9014 and Zeneca - 8392, cycle precocious, with interaction genotype-environment to the local experimental conditions, under eight water stress levels.

The line source sprinkler system, randomized block experimental design, with subdivided plots in five replications was used. The irrigation control was based on tensiometers and meteorological elements (air temperature and Piché evaporimeter). The application of water sheets was effected when one of the controls indicated the capacity limit of the water available to plants.

It was observed that materials Zeneca - 8392 and Cargill - 806 surpassed the others relating to totalized leaf area index (LAI). There was no statistical difference between materials in relation to plant height. The least anthesis silking intervals (ASI) were observed in Zeneca - 8392 and Cargill - 806, while Agroceres - 9012 and Agroceres - 9014 showed higher ASI. The harvest index (HI) differed statistically between materials: Cargill - 806 showed the highest HI, followed by materials Agroceres - 9014 and Zeneca - 8392. The lowest HI observed was in material Agroceres 
- 9012, and the best relation between grain yield and WSL was observed in material Cargill - 806.

Regarding the water stress response coefficient (ky), material Zeneca - 8392 was shown to be more sensitive. The lowest ky value was observed in material Agroceres 9012.

The leaf area index (LAI), grain yield (kg.ha ${ }^{-1}$ ), and water use efficiency (WUE) showed decreasing proportionalities in the presence of the water stress levels imposed, presenting different response intensities among corn materials.

Based on the evaluated indices, it was shown that Agroceres - 9014 and Zeneca 8392 are the most sensitive to water stress, and Cargill - 806 and Agroceres - 9012 showed the highest stability in the presence of the water stress levels to which they were submitted and, thus, offer the lowest risk conditions for off-season cultivation. 


\section{INTRODUÇÃO}

O milho cultivado extemporaneamente (outono - inverno) em regime de sequeiro, é comumente denominado safrinha. Por ser uma modalidade recente de cultivo, e distinta de cultivo da safra normal caracteriza-se por desenvolver sob menor disponibilidade hídrica e térmica, o que torna necessári o tecnologias mais específicas e apropriadas à sua produção.

O milho (Zea mays L.) é uma espécie vegetal com várias raças e enorme diversidade de variedades, sendo alvo de intensa pesquisa em melhoramento genético. Como resultado dessas pesquisas, diversos materiais genéticos têm sido lançados no mercado para semeaduras em diferentes ambientes, levando à necessidade de pesquisa sobre a interação genótipo-ambiente para adequação destes materiais às condições especificas de ambiente.

A indicação de um material genético para cultivo é um dos fatores mais importantes a ser considerado na otimização da produtividade nos cultivos de milho. Nos últimos 20 anos, os melhoristas brasileiros voltaram-se também para a obtenção de materiais superprecoces, o que vem possibilitando maior produtividade em menor tempo. Entretanto, devido à alta atividade metabólica desses materiais, a presença da interação genótipo-ambiente pode ser restringida nas diferentes regiões produtivas.

Outro aspecto considerável dos materiais superprecoces é que os mesmos se apresentam como boa alternativa de cultivo em sucessão à soja (Glicyne max Merril L.), em lavouras de sequeiro. Assim, a ocorrência de períodos em que o limite de água disponível no solo atinja níveis inferiores ao armazenamento crítico no período de cultivo de safrinha 
ou atraso na semeadura da soja, aumenta em muito os riscos desta sucessão de cultivo. $O$ milho safrinha ganhou maior impulso no início da década de 80 , quando todo apoio oficial à produção de trigo foi desmontado. Atualmente pelos preços atraentes da soja, que provocam redução na área plantada de milho, o cultivo extemporâneo tem se intensificado. De acordo com o levantamento realizado em fevereiro de 1998, a CONAB estima uma área de 2,24 milhões de hectares contra 2,09 milhões plantados no ano anterior, um crescimento de $6,9 \%$ na produção de milho safrinha.

Portanto, materiais mais tolerantes ao estresse hídrico, ou que apresentem menor demanda evapotranspirativa no estádio crítico (reprodutivo), devem ser priorizados, minimizando-se os riscos e tornando este sistema de produção mais seguro nos solos do cerrado no estado de Mato Grosso. Isso se justifica frente ao reduzido número de propriedades que utilizam a técnica da irrigação no estado (13\%), em que a área irrigada total compreende somente $1,9 \%$ das áreas totais de lavouras (IBGE, 1997). É de se considerar que no cultivo de milho safrinha, as produtividades médias locais oscilam em torno de $60 \%$ a $70 \%$ do potencial observado nos períodos de safra, explicado pelas restrições causadas pela menor disponibilidade de água e fatores climáticos (térmicos).

O presente trabalho apresenta-se com o objetivo de avaliar os efeitos do estresse hídrico e características agronômicas em materiais superprecoces de milho com interação genótipo-ambiente, às condições de cerrado do estado de Mato Grosso. 


\section{REVISÃo BIBLIOGRÁFICA}

\subsection{Milho (Zea mays L.), situação atual}

A fronteira de áreas cultivadas com milho nos dias de hoje assume novos contornos. A região centro-oeste, a principal área de expansão da agropecuária brasileira, praticamente triplicou sua superfície agrícola desde o início dos anos 70 , principalmente no ecossistema tipo cerrado. O cerrado é uma região de bom índice de precipitação, predominando valores anuais médios entre 1000 e $2000 \mathrm{~mm}$, porém com sazonalidade. Há forte concentração de chuvas no verão e outono, para a maior parte da região, caracterizada por excesso de água e intenso escoamento superficial, enquanto que inverno e primavera são estações marcadas por elevada deficiência hídrica, solos secos e vazante nos rios (Nimer \& Brandão, 1989).

A adoção de tecnologias apropriadas à produção de milho tem efeito direto na sua produtividade, elevando-a em níveis superiores a $6.000 \mathrm{~kg} \cdot \mathrm{ha}^{-1}$ (sistema de produção agrícola com elevado nível tecnológico). Produtividades da ordem de 4.500 a 6.000 $\mathrm{kg} . \mathrm{ha}^{-1}$, de boa a alta tecnologia caracterizam sistemas intermediários. Uma terceira classe, representando a maioria, é constituída pelos que colhem menos do que 4.000 $\mathrm{kg} \cdot \mathrm{ha}^{-1} \mathrm{e}$ ainda àqueles que se encontram com rendimentos inferiores aos $4.000 \mathrm{~kg} . \mathrm{ha}^{-1}$, condição esta, atualmente, inviável.

A comparação em nivel nacional, de cultivos de safra (verão) e safrinha (outonoinverno), em relação à expansão da área de cultivo, produção e produtividade no período de 1993 a 1997, é apresentada no Anexo A. 
Segundo Nussio (1990), o milho em função de sua composição química e valor nutritivo, destaca-se como um dos mais importantes cereais cultivados e consumidos em todo o mundo, seja na alimentação humana ou animal. É responsável por cerca de $15 \%$ da proteína produzida anualmente no mundo pelas culturas alimentares e representa $19 \%$ das calorias alimentares do mundo (Pandey et al., 1995). Devido à multiplicidade de seu emprego nos diversos segmentos da atividade humana, desempenha importante papel sócio-econômico, além de constituir matéria prima de diversificados complexos industriais, utilizando grande contigente de mão-de-obra em seu processo produtivo.

Dentre os vegetais, o milho é a planta mais estudada no campo da genética, o que resultou em significativa contribuição para o melhoramento de suas características de interesse econômico. O potencial produtivo apresentado pelos materiais de milho nas últimas quatro décadas passou de pouco mais de $3.000 \mathrm{~kg} \cdot \mathrm{ha}^{-1}$, no final dos anos 40 , para mais de $12.000 \mathrm{~kg} \cdot \mathrm{ha}^{-1}$, no final da década de 80 . Embora possuam contribuição única e atributos que os habilitam a atingir altas produtividades, a produção final não depende exclusivamente das cultivares, mas resulta de sua interação com o ambiente, disponibilidade de água e de energia, temperatura, nutrientes e população de plantas (Fundação Instituto Agronômico do Paraná-FIAPAR, 1991). Considerando áreas com características adequadas, sob o aspecto edafoclimático, a dimensão potencial para produção de milho no estado de Mato Grosso, em escala macro, são mostrados nos Anexos B e C.

De acordo com dados da Empresa Brasileira de Pesquisa AgropecuáriaEMBRAPA (1993), o milho é produzido em quase todo o território brasileiro, nas mais diferentes regiões e com os mais diferentes tipos de produção, invalidando qualquer tentativa de homogeneização que se procura dar ao tema.

Dentre os insumos utilizados na lavoura do milho as sementes melhoradas são de especial importância, pois agregam fatores como produtividade, tolerância a pragas $\mathrm{e}$ doenças, resistência a condições adversas de clima e solo, entre outros. A escolha do material de milho adequado para cada condição específica é importante fator de acréscimo na produtividade sem qualquer custo da produção. 
Maluf et al. (1983), estudaram o zoneamento agroclimático da cultura do milho concluindo que a resposta das diferentes cultivares pode variar uma vez que tem exigências térmicas e hídricas diferentes para germinação, desenvolvimento inicial, florescimento e maturação, reforçando a importância da experimentação local.

Dado a sua amplitude de adaptação (desde $58^{\circ} \mathrm{N}$ até $45^{\circ} \mathrm{S}$ de latitude, e de 0 a $3600 \mathrm{~m}$ de altitude), exigências bioclimáticas de um material e condições locais são associações viabilizadas pelos materiais genéticos com interação genótipo ambiente. Atualmente, é bastante diversificado o número de materiais que são comercializadas no Brasil. Com relação ao ciclo cultural, estes diferenciam-se em normais, 915 - 1200 ${ }^{\circ} \mathrm{C}$.dia; 60 a 65 dias para ocorrência do florescimento masculino; precoces 830 - 900 ${ }^{\circ} \mathrm{C}$.dia; 62 dias para ocorrência do florescimento masculino (110 - 120 dias de ciclo) e, superprecoces $780-825^{\circ} \mathrm{C}$ dia; 55 dias para ocorrência do florescimento masculino e 105 a 120 dias de ciclo (SEMINÁRIO SOBRE FISIOLOGIA DA PRODUÇÃO E MANEJO DE ÁGUA E DE NUTRIENTES NA CULTURA DO MILHO DE ALTA PRODUTIVIDADE, 1996 e Viégas, 1989).

Materiais superprecoces vêm sendo muito pesquisados pela alta capacidade no aproveitamento de energia, constituindo-se em boa alternativa por possibilitar maior produtividade por adoção de plantios mais densos, com menor risco de acamamento, devido ao seu porte mais reduzido e melhor arquitetura. Permitem também a sucessão com outras culturas no mesmo ano agrícola; a semeadura antecipada ou plantio de safrinha; e a melhor utilização da mão-de-obra, de máquinas e implementos na propriedade (Fornasiere Filho, 1992).

Os materiais superprecoces caracterizam-se por apresentar porte baixo, com 6 a 8 folhas abaixo e acima da espiga, e apresentam florescimento masculino normalmente abaixo de 60 dias. São materiais que apresentam uma menor produtividade por planta, devido à maior precocidade do milho, que não aproveita todo o período de crescimento, o que é compensado pelo plantio mais denso que proporciona maior produtividade nas densidades acima de 55.000 plantas. ha ${ }^{-1}$ até 70.000 plantas. ha $^{-1}$. De acordo com ensaio nacional de milho precoce, constatou-se que a média de dias para o florescimento é de 
68 dias, enquanto que a média para híbridos normais é de 80 dias (Pereira e Santos, 1982).

Pereira (1990), estudando caracteres agronômicos correlacionados com a produção ao longo dos trabalhos de melhoramento genético em milho, sugere um ideotipo de milho, que deve assumir as seguintes características: planta mais precoce, maior período de enchimento de grãos (stay green) com reduzido número de dias para o florescimento, maior prolificidade, menor área foliar, folhas mais eretas com menor ângulo foliar propiciando aumento da densidade de cultivo, visando alcançar niveis ótimos de índice de área foliar-IAF. Além disso, deve apresentar relação entre altura da espiga e altura da planta na faixa de 0,45 a 0,50 , ter pendão com menor número de ramificações e de 8 a 9 folhas acima da espiga.

Tollenaar \& Daynard (1978) estudaram a senescência foliar em híbridos de milho de ciclo curto e observaram que $60 \%$ de senescência foliar é alcançada 9 dias antes da formação da camada escura e que várias folhas abaixo do dossel senescem durante os estágios iniciais de enchimento de grãos. A senescência foliar em híbridos de ciclo curto ocorre, portanto, antes da formação da camada escura e pode ser ocasionada pela baixa reserva de assimilados no final do período de enchimento de grão (Daynard \& Duncan, 1969). Em contraste, nas regiões tropicais a senescência foliar de híbridos de ciclo curto ocorre durante ou após a formação da camada escura (Duncan, 1969). Híbridos superprecoces vêm assumindo grande importância, não só pelo ciclo mais curto, mas por permitir a produção nas mais diversas regiões.

Brunini (1984), verificando o efeito do ciclo em produção de híbridos, estudou 6 materiais diferentes e encontrou maior eficiência produtiva em híbrido duplo superprecoce (C-601) em contraste a um hibrido duplo tropical (IAC-8222) de ciclo mais tardio pelo fato do superprecoce possibilitar melhor penetração da radiação fotossintética ativa no interior do dossel e acentuada translocação de sólidos solúveis dos diferentes órgãos da planta para os grãos. Além disso, observou que o acúmulo de matéria seca por híbrido precoce é maior que híbrido normal, tanto no órgão como no sabugo e menor nas brácteas, caule e folhas. 
Calvache et al. (1982), estudando híbrido normal e superprecoce, não notaram grandes diferenças quanto à assimilação de nitrogênio, mas quanto ao acúmulo de cálcio e magnésio os superprecoces acumulam mais que os normais. Esses híbridos superprecoces utilizam melhor a adubação nitrogenada e apresentam melhor adaptação às áreas com restrições térmicas e hídricas (Viégas, 1989).

Segundo Machado et al. (1985), a taxa assimilatória líquida (TAL) em condições não irrigadas, a eficiência de híbridos superprecoces e de normais, constataram que os híbridos superprecoces possuem maior eficiência (TAL) após os 50 dias de emergência e antes dos 30 dias, em relação aos normais que têm maior eficiência nos 30 dias após a emergência. Brunini (1984), realizando a mesma pesquisa, porém sob condições de alta precipitação, constatou que, até os 30 dias após a emergência os híbridos normais e superprecoces possuem a mesma taxa assimilatória líquida e, depois dos 30 dias, o superprecoce possui uma maior taxa assimilatória líquida, por consegüinte maior quantidade de matéria seca produzida.

Com respeito ao fotoperíodo, o milho é considerado como planta neutra ou de dias curtos, porém, seu desenvolvimento é afetado pela quantidade de radiação solar e as maiores produtividades são obtidas em condições de alta radiação. Apresentando, ainda, a característica de fixar $\mathrm{CO}_{2}$ pelo metabolismo $\mathrm{C}_{4}$, implicando em maior eficiência no uso da água, tendo, sob condições de alta intensidade de radiação e de alta temperatura, elevadas taxas de fotossintese e crescimento (Volpe, 1986).

As plantas $\mathrm{C}_{4}$ têm 2,5 a 3,0 vezes maior eficiência no uso da água que as plantas $\mathrm{C}_{3}$ (Boyer, 1976). Além de sua anatomia foliar característica (maior proximidade dos feixes vasculares das células produtoras de carbohidratos da bainha vascular das folhas, Síndrome de Kranz), as plantas com metabolismo $\mathrm{C}_{4}$ distinguem-se das demais por apresentarem baixa perda de $\mathrm{CO}_{2}$ na luz (fotorespiração) e baixo consumo de água por unidade de matéria seca produzida, mesmo com boa eficiência no uso da água. Essa característica das plantas $\mathrm{C}_{4}$ não confere maior tolerância à seca, pois existem plantas $\mathrm{C}_{3}$ mais tolerante que o milho. Magalhães e Silva (1987), assinalaram que, em geral, o milho por ter metabolismo tipo $C_{4}$ apresenta fotossintese líquida da ordem de 50 a 70 
mg. $\mathrm{CO}_{2} \cdot \mathrm{dm}^{-2}$.hora ${ }^{-1}$, enquanto que plantas como do tipo $C_{3}$ fixam $\mathrm{CO}_{2}$ a taxas muito baixas, entre 15 a $35 \mathrm{mg} \cdot \mathrm{CO}_{2} \mathrm{dm}^{-2} \cdot \mathrm{h}^{-1}$.

Em média, a cultura do milho requer temperatura entre 24 e $32{ }^{\circ} \mathrm{C}$, porém, quando a disponibilidade de água do solo for baixa, a temperatura ótima para seu crescimento fica abaixo de $27^{\circ} \mathrm{C}$ (Waldren ${ }^{1}$ citado por Pimentel \& Rossielo, 1995).

Quanto à resposta de cultivares sob diferentes densidades populacionais, Troyer (1968) observou que híbridos superprecoces de menor porte suportam alta densidade de semeadura enquanto que híbridos de milho normais de porte alto produzem menos em altas densidades.

Duncan (1958) observou que híbridos precoces de milho, quando em densidades baixas, dão produção menor que os híbridos tardios, mas em densidades altas, sem restrições de ordem nutricional, o milho precoce supera o milho tardio em produção. Carson et al (1966) avaliaram a produtividade de grãos em híbridos de milho de ciclo normal, precoce e superprecoce em três densidades de semeadura $(48.000,72.000 \mathrm{e}$ 96.000 plantas. ha ${ }^{-1}$ ) e concluíram que o híbrido normal apresentou maior rendimento na densidade menor (48000) e os híbridos precoces e superprecoces superaram o normal, em média, $15 \%$ da produção nas densidades mais elevadas. Trabalhando com três densidades de plantio $\left(33.333 ; 55.555\right.$ e 77.777 plantas. ha $\left.^{-1}\right)$, com materiais de ciclo normal, precoce e superprecoce, Durães (1993) encontrou rendimentos crescentes com o aumento das densidades, sendo os materiais precoces, superiores aos de ciclo normal e superprecoce, na condição de maior densidade.

Domenack (1980) observou a relação entre densidade populacional, absorção de radiação solar e produção para um material superprecoce e verificou que na maior densidade a produção de matéria seca de grãos foi maior do que nas menores densidades. Brunini et al. (1983) verificaram que os materiais superprecoces permitem uma melhor penetração da radiação solar no dossel da planta, ocasionando menores valores de resistência estomática nas folhas inferiores, justificando a utilização de plantios mais densos com materiais superprecoces. Segundo Pereira e Santos (1982), os

\footnotetext{
${ }^{1}$ WALDREN, R. P. Corn. In: TEARE, I. D.; PEET, M. M. Crop water relations. eds. Jonh Wiley e Sons Publi, 1983. p.187-211.
} 
híbridos proporcionam menores sombreamentos, e assim densidade de semeadura maior, menores taxas de acamamento e quebra de colmos em relação aos híbridos normais, além da colheita ser realizada mais cedo.

Twvmasi-Afriyie \& Hunter (1982) constataram que, em densidades de plantio mais baixas, o acamamento é menor do que em densidades de plantio mais altas em híbrido de milho superprecoce. Cross et al. (1987) avaliaram os efeitos da densidade de plantio, maturidade e prolificidade e constataram que os híbridos precoces têm um melhor desempenho em densidade maiores do que os híbridos tardios, além de possuírem menor período de enchimento de grãos. Os referidos autores ainda mencionam que os híbridos precoces são superiores na produção de grãos, e apresentaram um maior número de espiga por planta e sementes mais pesadas.

Apesar disso, os híbridos de milho precoce são mais susceptíveis ao acamamento do caule do que os híbridos de milho de ciclo tardio. Viégas (1989) constatou as boas características que o milho superprecoce possui, permitindo que seja cultivado em rotação com outras culturas, especialmente soja e trigo. Em regiões açucareiras, por ocasião das reformas dos canaviais no período de outubro a fevereiro, o cultivo do milho precoce vem sendo amplamente recomendado.

A temperatura como principal elemento meteorológico relacionado ao desenvolvimento das plantas de milho está evidenciada em vários trabalhos (Tollenaar \& Hunter, 1983); (Russel \& Stuber, 1983) e (Stewart et al., 1998). Muchow \& Sinclair (1991) ressaltam o importante papel da temperatura na duração do desenvolvimento do grão, pois a matéria seca acumulada no grão de milho é devida, principalmente, à matéria seca acumulada após a floração. Outro processo bastante afetado é o acúmulo de reservas no colmo, as quais resultam da alta atividade fotossíntética, sobretudo por volta do período de floração. Sob baixos níveis de radiação solar e de temperatura durante essa fase do milho safrinha, o acúmulo de reservas pode ser restringido e, assim, limitar o enchimento dos grãos (Noldim, 1985). Igualmente importante é a translocação das reservas na planta.

Kage (1983) observou que no consórcio de milho com mucuna e em rotação com soja precoce, a utilização de híbridos precoces pode ser recomendada. Além disso, 
no sistema de semeadura direta (Muzilli, 1985) os híbridos superprecoces são mais indicados, pois possuem maior resistência ao acamamento e às moléstias, além de utilizarem melhor os fertilizantes, características essas, requeridas para esse sistema de cultivo.

\subsection{Milho (Zea mays L.) em cultivo extemporâneo (safrinha)}

Iniciado na década de 80 , no oeste do Estado do Paraná, o cultivo extemporâneo de milho tem-se consagrado cada vez mais como opção rentável, seja economicamente ou do ponto de vista de conservação do solo, em sucessão ao cultivo de soja, principalmente no Estado de Mato Grosso. Esta época de cultivo predispõe as plantas a uma frequência maior de veranicos, acarretando em significativo decréscimo na produção de grãos. O cultivo extemporâneo de milho, além de constitui-se em fonte adicional de renda para o produtor, possibilita também crescente estabilização da produção e dos estoques de milho.

Ocorrência de veranicos, com o estabelecimento de estresse hídrico na planta, é caracterizada por uma redução do seu conteúdo de água e do seu potencial hídrico, resultando em perda de turgescência, fechamento dos estômatos e redução no crescimento.

Dentre os principais efeitos tem-se: redução na fotossíntese e no crescimento (Kramer, 1974); o crescimento radicular é geralmente favorecido comparado ao crescimento total que é reduzido (Davidson, 1969; Hoffman et al., 1971; Lancher, 1975; Begg \& Turner, 1976); redução na transpiração das plantas (Crafts, 1968; Hsiao \& Acevedo, 1974; Sutcliffe, 1980); redução inicial na respiração, seguida de um aumento transitório e, finalmente, de uma diminuição ao aumentar o período da deficiência hídrica; redução da translocação de compostos orgânicos, como tem sido relatado por Roberts (1964), e por Plaut \& Reinhold (1965).

Em recente artigo apresentado no IV Seminário Sobre a Cultura do Milho Safrinha, Tsunechiro e Arias (1997) mostram análise da rentabilidade financeira e perspectivas de crescimento para o milho safrinha nos Estados de Paraná, São Paulo, Mato Grosso do Sul, Mato Grosso e Goiás demonstrando o ponto de equilíbrio 
econômico (receita.despesa ${ }^{-1}$ ), que é bem inferior ao sistema de produção verão-outono (safra). Em Mato Grosso, este tipo de cultivo tem crescido nos últimos 5 anos. Atualmente, o milho safrinha é responsável por $34 \%$ da produção total de milho ( $16 \%$ da produção nacional) mas, com produtividade média (últimas três safras) em torno de $2.075 \mathrm{~kg} \cdot \mathrm{ha}^{-1}$, reforçando a escassez de tecnologias adequadas a este sistema de produção.

Brunini et al. (1983) constataram que materiais superprecoces possuem menor evapotranspiração do que as cultivares de ciclo normal até os 76 dias após a emergência e maior após esses 76 dias. Constataram também que a matéria seca produzida por unidade de água evapotranspirada (eficiência no uso da água) é melhor em materiais superprecoces de milho do que em normais e a produção de grãos e de espigas também é maior, mostrando com isso melhor utilização da água pelos materiais superprecoces. Os materiais genéticos de ciclos mais curtos têm sido largamente recomendados nos mais diversos ambientes de produção.

\subsection{Balanço hídrico em condições de campo}

O balanço hídrico é a contabilidade da quantidade de água que entra e sai num volume de solo considerado, num intervalo de tempo, resultando na lâmina de água que nele permanece armazenada (Reichardt, 1985). A metodologia do balanço hídrico num volume de controle de solo nas modalidades sequencial e cíclico, tem sido largamente utilizada em pesquisas de uso consuntivo de água, entre outros destaca-se: Rose \& Stern (1967); Pereira (1986); Reichardt (1974); Castro (1979) e Oliveira (1991). A quantidade de cada um dos componentes do balanço hídrico (precipitação, irrigação, fluxo no perfil, evaporação e transpiração pelas plantas), ao longo do ciclo de uma cultura, permite ^ avaliação da variação da água no solo, das perdas por evaporação ou por drenagem profunda, da sua extração pelas plantas, além de fornecer subsídios a tomada de decisões de quando e quanto irrigar, promovendo um bom manejo da irrigação. Alguns trabalhos têm evidenciado a importância quantitativa da componente de fluxo descendente no perfil, como são mostrados por Stone et al. (1973) e Souza et al. (1979). 
Libardi \& Saad (1994), empregando metodologia de balanço hídrico a campo na cultura do feijão (Phaseolus vulgaris L.), demostraram que o tensiômetro é um sensor adequado para controlar as irrigações, perdas de água pela cultura e cálculo da lâmina requerida.

A determinação dos componentes da equação do balanço hídrico podem ser feita de várias maneiras devendo-se deixar um deles como incógnita, o qual, geralmente, é o fluxo causado pela evaporação da superficie do solo mais a transpiração das plantas, (evapotranspiração). Os métodos de medição de evapotranspiração podem ser classificados em: depleção de água do solo; dos tanques e lisímetros; do balanço de água; do balanço de energia e combinação do balanço de energia e transferência de calor e massa (Jensen, 1974).

No balanço hídrico sob condições de campo, o monitoramento da aplicação e depleção de água num volume de controle de solo pode se dar dentre outras maneiras pela técnica da aspersão em linha (Hanks, 1974; Hanks et al., 1976). Essa técnica consiste de uma tubulação composta de aspersores rotativos, com um padrão de distribuição de água triangular que proporciona gradiente contínuo e decrescente ao longo do raio molhado dos aspersores e, com as parcelas experimentais dispostas transversalmente à tubulação. Além de níveis de água esse sistema permite o estudo simultâneo de outras variáveis, aplicadas perpendicularmente aos níveis de água adequando-se perfeitamente para o desenvolvimento de funções de produção do tipo superficie de resposta. É um método econômico de simplicidade operacional, mas, apresenta a limitação de funcionamento sob condições de calmaria. Do ponto de vista científico, sua maior limitação consiste na impossibilidade de randomização dos níveis de água, tornando viciada a estimativa do erro experimental (Steel \& Torrie, 1980). Uma sistemática de decomposição da análise de variância pode ser vista em Hanks et al., (1980) e informações complementares são encontradas em Fernandez, (1991) e Morgan, (1988).

O fato é que a não randomização do fator lâmina de água ou de níveis de estresse hídrico na aspersão em linha acarretará erros nos testes de hipóteses quando o efeito esperado da variável água for muito reduzida. Entretanto, existe a possibilidade da 
análise por meio da estatística não paramétrica ou outros critérios para análise da hipótese proposta.

Apesar do reconhecimento da limitação inerente por se tratar de um delineamento sistemático para o fator água, o método do sistema de aspersão em linha tem sido amplamente utilizado para diversas culturas e com as mais diferentes finalidades. Dentre os trabalhos que empregaram tal sistema para o estabelecimento de funções de produção ou análise da eficiência no uso da água, entre outros tem-se: Rasmussen \& Hanks (1978); Aragon \& Datta (1981); Couto et al. (1981); Faria (1981); Puckridge \& O'Toole (1981); Novero et al. (1985); Tyem \& Chieng (1985); Frizzone (1986); Faria \& Olitta (1987); Seetharama (1987); Folegatti (1988); Pfeiffer et al. (1990); Smittle et al. (1990); Cunha (1991); Ismail (1993); Sepaskhah \& Liampour (1995) e, especificamente com a cultura do milho tem-se: Wicks \& Carson (1987); Braunworth \& Mack (1989); Silva (1990); Cosculluela \& Faci, (1992); Mendonça, (1994); etc.

A relação entre a taxa de evapotranspiração e a tensão de umidade do solo depende de fatores como a textura do solo, condutividade hidráulica e difusividade do do solo, profundidade e desenvolvimento do sistema radicular, densidade da vegetação $\mathrm{e}$ condições atmosféricas (Kramer, 1969; Denmead \& Shaw, 1962; Reichardt, 1985). A redução do teor de umidade do solo, com conseqüente redução do potencial de água, pode causar um desbalanceamento no equilíbrio de potenciais necessários à manutenção de uma dada taxa de transpiração, fazendo com que essa se reduza com o fechamento dos estômatos (Gardner, 1960). O processo de evapotranspiração, conseqüência de fluxos de água no sistema solo-planta-atmosfera, é completamente dinâmico, fugindo de conceitos de estados estáticos, assim toda vez que o sistema conseguir catalisar o fluxo de água, sentido solo-planta-atmosfera, a evapotranspiração acontecerá e a água da solução do solo estará disponivel. Num adequado manejo de irrigação a quantidade de água a ser aplicada a cultura é a diferença entre a demanda evapotranspirativa e a precipitação efetiva (Silva, 1993). 


\subsection{Aspectos morfo-fisiológicos na produção de milho}

A água, como fator de produção, tem seu limite crítico inferior quando os processos vitais das plantas são comprometidos, portanto, os valores de potencial hídrico nos quais esses processos fisiológicos são afetados são variáveis entre diferentes materiais de milho, evidenciando a importância de parâmetros morfo-físiológicos associados a niveis de estresse hídrico. Dada a amplitude de adaptação dos diversos materiais de rnilho, exigências bioclimáticas dos materiais e condições locais de cultivo são interessantes associações que podem ser viabilizadas por tais materiais.

Todos os aspectos do crescimento vegetal são afetados pela falta de água. Uma pequena redução nos potenciais de água no solo desencadearia um aumento na concentração de ácido abscísico-ABA no xilema, induzindo o fechamento estomático e redução da expansão do limbo foliar, redução da atividade fotossintética face à redução na oferta de $\mathrm{CO}_{2}$. Outro aspecto associado ao estresse hídrico seria a redução de biossíntese de proteínas e da atividade de enzimas como a redutase de nitrato, teor de prolina livre na folha (Ferreira, 1997).

Há evidência de alta correlação entre o acúmulo de amoniácidos livres (prolina) e a tolerância à seca (Hsiao, 1973), apesar de diversos outros trabalhos a contradizer (Hanson \& Hitz, 1982). Não existe um único parâmetro que por si só seja indicativo de tolerância à seca.

A complexidade dos elementos que afetam o crescimento das culturas agricolas podem ser simplificadas e expressadas por alguns índices que traduzem de forma satisfatória o desenvolvimento das plantas. A análise quantitativa do crescimento vegetal, desenvolvida, primeiramente, por fitofisiólogos da escola inglesa é considerada internacionalmente como o método padrão para estimativa da produtividade das comunidades vegetais. Por meio da análise de crescimento avalia-se a produção líquida das plantas derivadas do processo fotossintético, o qual é o resultado do desempenho do sistema assimilatório durante um certo período de tempo (Magalhães, 1979).

No milho não existe correlação entre alta taxa fotossintética e produtividade. Dessa consideração, denota-se a importância de se observar o fluxo de carbono na planta, ou seja, a partição de fotoassimilados para grãos. A força dos centros de consumo 
(dreno) é que determina o padrão de distribuição de metabólitos na planta alocando-os a partir da fonte (centro de produção). Em geral, a força dos drenos é condicionada pelo número, dimensão, proximidade, sincronia e taxa de crescimento dos grãos de acumulação de assimilados (Evans, 1975). Snyder \& Carlson (1984) discorrem sobre seleção para partição de produtos fotossintéticos nas culturas que, numa abordagem genérica, mostram as tentativas de vários pesquisadores em modelar o crescimento quantitativo das plantas e respectiva partição. Específicamente para a cultura do milho, os autores citam entre outros: MacKinnon (1979); Evans, (1975) etc, em que a precisão da predição desse é limitada em função da translocação e partição de produtos fotossintéticos envolver um processo complexo que não foi ainda devidamente elucidado.

Alguns trabalhos têm mostrado o regime de temperatura, dentre outros como elemento influenciador na partição de fotoassimilados (Tollenaar, 1989). Dados da literatura indicam que quanto mais rapidamente crescem os órgãos que compõem os drenos maior será o gradiente de concentração de assimilados no floema, permitindo a importação de materiais de fontes mais distantes.

A razão entre o peso dos grãos e o peso da matéria seca total (índice de colheita (IC), expressa a razão entre a produtividade econômica e a biológica (Sakai, 1996). Portanto o rendimento de grãos de uma cultura pode ser definido como sendo o produto entre o rendimento biológico e seu respectivo IC. O rendimento biológico refere-se ao somatório de todos os órgãos das plantas e o rendimento econômico, no caso os grãos de milho, é consequiência da interação genótipo $\mathrm{x}$ ambiente $\mathrm{x}$ manejo.

$O$ índice de colheita se constitui, então, na fração dos grãos produzidos em relação à matéria seca total da planta. Singh \& Stoskopf ${ }^{2}$, citados por Donald \& Hamblin (1976), correlacionando o IC do trigo, cevada e aveia e outras partes da planta constatam que houve correlação negativa com os componentes individuais vegetativos. Observa-se que o IC, além do germoplasma ser amplamente influenciado por elementos do ambiente sendo por si só um fator não decisivo na caracterização de um material mas,

\footnotetext{
${ }^{2}$ SINGH, I. D.: STOSKOPF, N. C. Harvest index in cereals. Agronomy Journal, Madison, v.63, n.2, p.224-226, 1971.
} 
apontando como característica importante quando se tem materiais com interação genótipo-ambiente. SEMINÁRIO ..., (1996), citam que o IC máximo para a cultura do milho encontra-se próximo ao valor de 0,6 (climas temperados e a elevadas altitudes). Os autores ainda citam que IC menores são oriundos de países da África (Quênia, IC = 0,10 ; Gana, $\mathrm{IC}=0,27$; etc).

Materiais de milho tropical acumulam mais matéria seca nas partes vegetativas da planta do que nas reprodutivas após a antese, sendo relativamente mais deficitária e variável em relação à partição da matéria seca do que as cultivares de milho de região de clima temperado, conclusão essa, apresentada em Goldsrorth \& Colegrove (1974) e Goldsrorth et al. (1974). O rendimento do milho é limitado pelo tamanho e amplitude do dreno, o que, em materiais tropicais, é atribuído à competição entre as partes vegetativas (folha, colmos e brácteas) e a espiga.

Durães (1993) recomenda, para cultivo em safrinha, materiais que tenham larga capacidade de dreno e que acumulem rapidamente matéria seca em seus órgãos, continuando ainda, a acumular, paralelamente ao enchimento de grãos, matéria seca total.

Porém, Fancelli (1986) ressalta que a maior habilidade de partição relacionada aos materiais superprecoces e precoces somente poderá se manifestar, quando forem satisfeitas as exigências climáticas e nutricionais relativas aos materiais genéticos considerados. Assim, a generalização do parâmetro IC para diferentes ambientes deve ser evitado. Como descrevem SEMINÁRIO .... (1996), em ocasiões em que os individuos de uma comunidade se submetam a relações de competição por recursos materiais e energéticos, sobreviverão aqueles que detiverem características adaptativas superiores de natureza morfológica, fisiológica e comportamental. Habilidade genética de particionar fotoassimilados para drenos estratégicos de sobrevivência e perpetuação da espécie vegetal é uma característica relevante (Cody, 1966).

Características morfo-fisiológicas em plantas de milho com presumido valor adaptativo sobre condições de seca são: redução do intervalo entre florescimento masculino e feminino (IFMF), temperatura do colmo fresco (TC), aumento relativo do colmo e taxa de alongamento da folha (TAF) e redução da taxa de senescência das 
folhas (RTSF). A TAF, TC, padrões radiculares, potencial de água, ajustamento osmótico, senescência da folha, não apresentaram progresso nessas características após oito ciclos de seleção, indicando que esses caracteres têm baixo valor adaptativo ou baixa herdabilidade (Bolaños \& Edmmeades, 1995). Atualmente, dentre os índices biofisicos utilizados pelo CENTRO INTERNACIONAL DE MELHORAMENTO DE MILHO E TRIGO (CIMMYT), tem-se o IFMF reduzido e alta produção de grãos em dois ou três ambientes, permitindo o uso de IC com mais eficiência na seleção de materiais tolerantes à seca e sob alta densidade de plantio.

Edmmeades et al., (1989) e Durães et al., (1997) utilizaram a característica IFMF reduzido como critério de seleção recorrente em populaçães de milho para tolerância à seca. Os trabalhos de seleção provavelmente apontarão germoplasmas de milho com esta característica fixada, permitindo sua inserção em programas de melhoramento possibilitando oferta no mercado, de materiais superprecoces com IFMF reduzido.

\subsection{Unidades calóricas}

São inúmeros os trabalhos relacionando variáveis climáticas com o desenvolvimento e rendimento na cultura do milho. Estes têm demonstrado as dificuldades de estabelecer correlações entre produtividade do milho e características ambientais para as diferentes regiões agrícolas do Pais. Mas a influência de variáveis climáticas no desenvolvimento e na caracterização de fases fenológicas já tem uso bastante difundido. A taxa de desenvolvimento pode ser afetada por diversos elementos ou variáveis, entre eles: fotoperíodo, umidade do solo, radiação solar e fertilidade, mas o principal é a temperatura (Gilmore \& Rogers, 1958; Cross \& Zuber, 1972 e Hodges, 1991).

O conceito de graus-dia, entendido como sendo a diferença entre a temperatura média diária e a temperatura basal exigida por uma espécie vegetal (Villa Nova et al. 1972), apóia-se na hipótese de que existe uma relação funcional entre o aumento da temperatura e o incremento no desenvolvimento das plantas dentro de certos limites. Esses limites são variáveis para diferentes espécies de plantas. 
Assume-se como limites para o milho, temperatura base igual a $10^{\circ} \mathrm{C}$ e superior igual a $30^{\circ} \mathrm{C}^{1}$, sendo a temperatura ótima entre 20 e $30^{\circ} \mathrm{C}$ (Viégas \& Peeten, 1987). Brown (1969), propõe método para estimativa de ${ }^{\circ} \mathrm{C}$ dia na cultura do milho, onde estabelece um relação entre a taxa diária de desenvolvimento do milho e as temperaturas diurnas (temperatura basal de $10^{\circ} \mathrm{C}$ ) e noturnas (temperatura basal de $4,4^{\circ} \mathrm{C}$ ).

A utilização do conceito de graus dia tem uso generalizado, seja para relacinarse a fenologia das plantas, seja para caracterização de parte ou do ciclo total. Dentre os pesquisadores tem-se: Gilmore \& Rogers (1958); Aspiazú \& Shaw (1972); Neild et al. (1978); Cardoso \& Mundstock (1979); Coelho \& Dale (1980); Neild (1982); Berlato et al. (1984); Bernardes et al. (1987); Bernardes (1989); Nunez, (1986) e Silva 1989). A principal restrição no uso do conceito de graus dia, reside no fato de que desenvolvimento vegetal e temperatura do ar não apresentam relação de linearidade universal. Douglas et al. (1998), no período de 1992 a 1995, em 19 locais no norte do Canadá, analisou a resposta fenológica do milho pela temperatura, e sugere a incorporação de funções de resposta para predição do desenvolvimento de plantas de milho. Em regiões onde a temperatura tem maior oscilação, estabelecendo com melhor precisão um resíduo a ser subtraído para temperatura máxima e mínima, provavelmente linearizaria melhor a função de resposta.

As análises entre estádios de desenvolvimento fenológico, feitas nos materiais de milho BR 201 e BR 206 com graus dia acumulados a partir da emergência, indicaram que $97 \%$ e $98 \%$ da variação total observadas nos estádios fenológicos foram explicados pelo acúmulos de graus-dia (Silva, 1995). Souza (1989) encontrou altas correlações entre o número de dias para o florescimento e o total de graus dia acumulados, realçando a importância do mesmo na predição das fases de desenvolvimento vegetal.

$\mathrm{O}$ uso de graus-dia atualmente tem sido largamente utilizado por alguns pesquisadores, tais como: Sentelhas et al. (1994) determinando temperaturas base e graus dia para diferentes cultivares de girassol; Pedro Júnior et al. (1994) em estudos

\footnotetext{
' A temperatura basal para cultivares tardios é maior do que aquela correspondente aos cultivares superprecoes e precoce (Berlato \& Sutili, 1976). Existem outras referências à temperatura basal para o milho diferente de $10^{\circ} \mathrm{C}$, tais como: $6^{\circ} \mathrm{C}$ (Bloc \& Gonest. 1976); $8^{\circ} \mathrm{C}$ (Brunini et al., 1981) e (Kyniry \& Bonhomme, 1991) e $9^{\circ} \mathrm{C}$ (Cirilo, 1994). In: Fancelli \& Dourado Neto, (1997).
} 
biometeorológico em videiras; Virgens Filho et al. (1997) entre outros pesquisadores das mais diversas culturas de interesse agronômico. Portanto pressupõe-se ser uma técnica de aceitação e de confiabilidade para predizer fases fenológicas ou ciclos totais das plantas. 


\section{MATERIAL E MÉTODOS}

\subsection{Local}

Desenvolveu-se a pesquisa no ano de 1997, em período com ocorrência de veranicos prolongados e ventos fracos (Oliveira et. al., 1997b), em área edafoclimaticamente representativa do ecossistema cerrado no estado de Mato Grosso, Brasil, dada pelas coordenadas geográficas $15^{\circ} 40^{\prime}$ latitude sul, $55^{\circ} 25^{\prime}$ longitude oeste e altitude de $780 \mathrm{~m}$, área de experimentação agrícola da Escola Agrotécnica Federal de CuiabáMT.

O solo é classificado ${ }^{1}$ como Latossolo vermelho escuro distrófico, A moderado, textura argilosa, savana arbórea/florestas de galeria, suave ondulado/ondulado. Suas características fisico-químicas são mostradas nas Tabelas 1 e 2 e, descrição morfológica, mineralógica e micromorfológica, Anexo D.

\subsection{Clima}

O local apresenta temperaturas média anual de $22,0^{\circ} \mathrm{C}$; com máxima anual de $31,5^{\circ} \mathrm{C}$; e mínima anual de $14,5^{\circ} \mathrm{C}$. A precipitação anual é de $1860 \mathrm{~mm}$ com duas estações distintas e bem definidas: chuvosa, de outubro a março, e seca, de abril a setembro. Evidências observacionais demonstram que uma parte considerável da umidade atmosférica do Brasil Central é oriunda da Amazônia centro-ocidental (Tarifa, 1994).

\footnotetext{
${ }^{1}$ Considerado critério da Classificação Brasileira de Solos. O correspondente na Classificação Americana de Solos é a ordem Oxisols. grande grupo Haplorthox do sub-grupo Typic harplothox.
} 

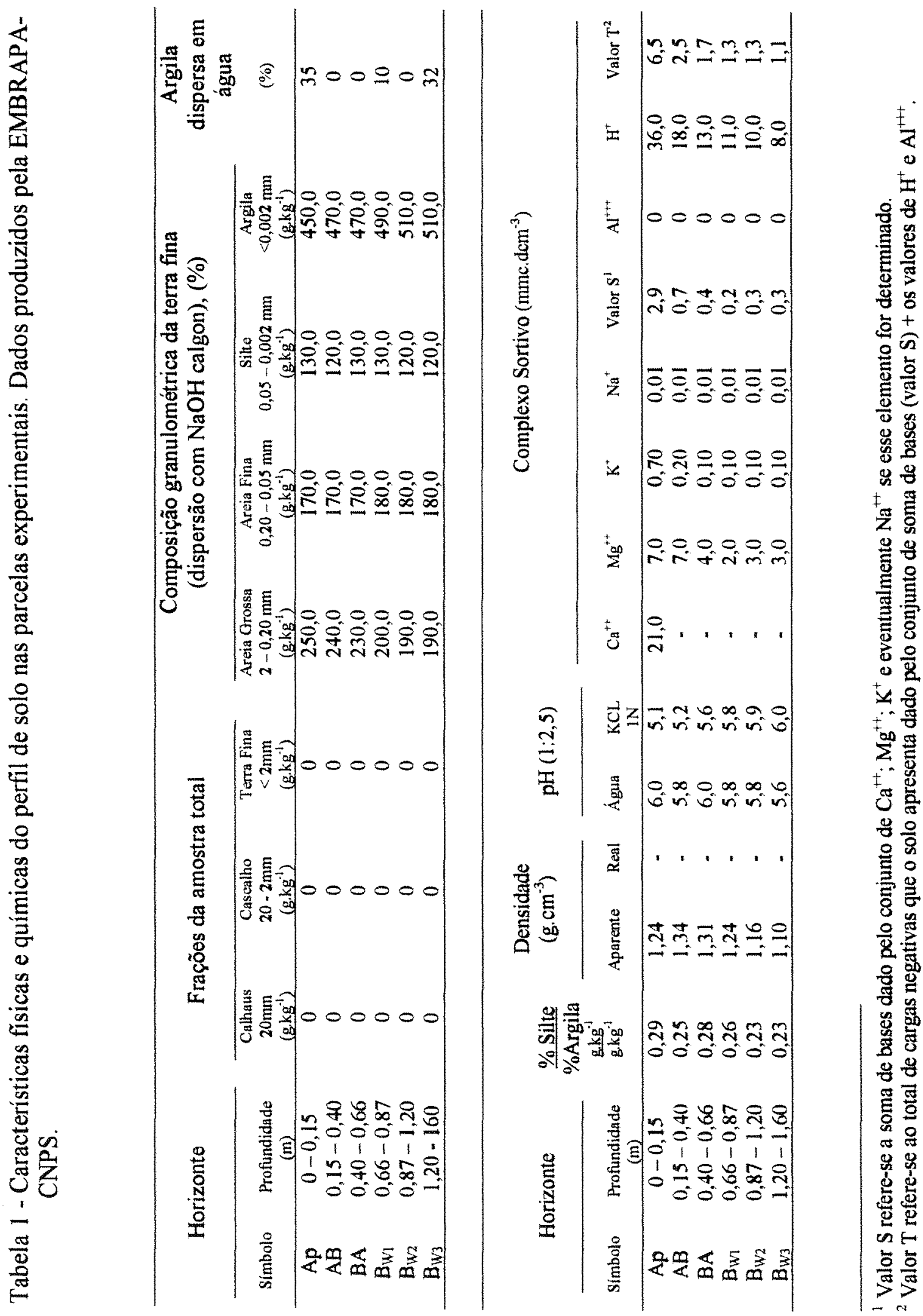

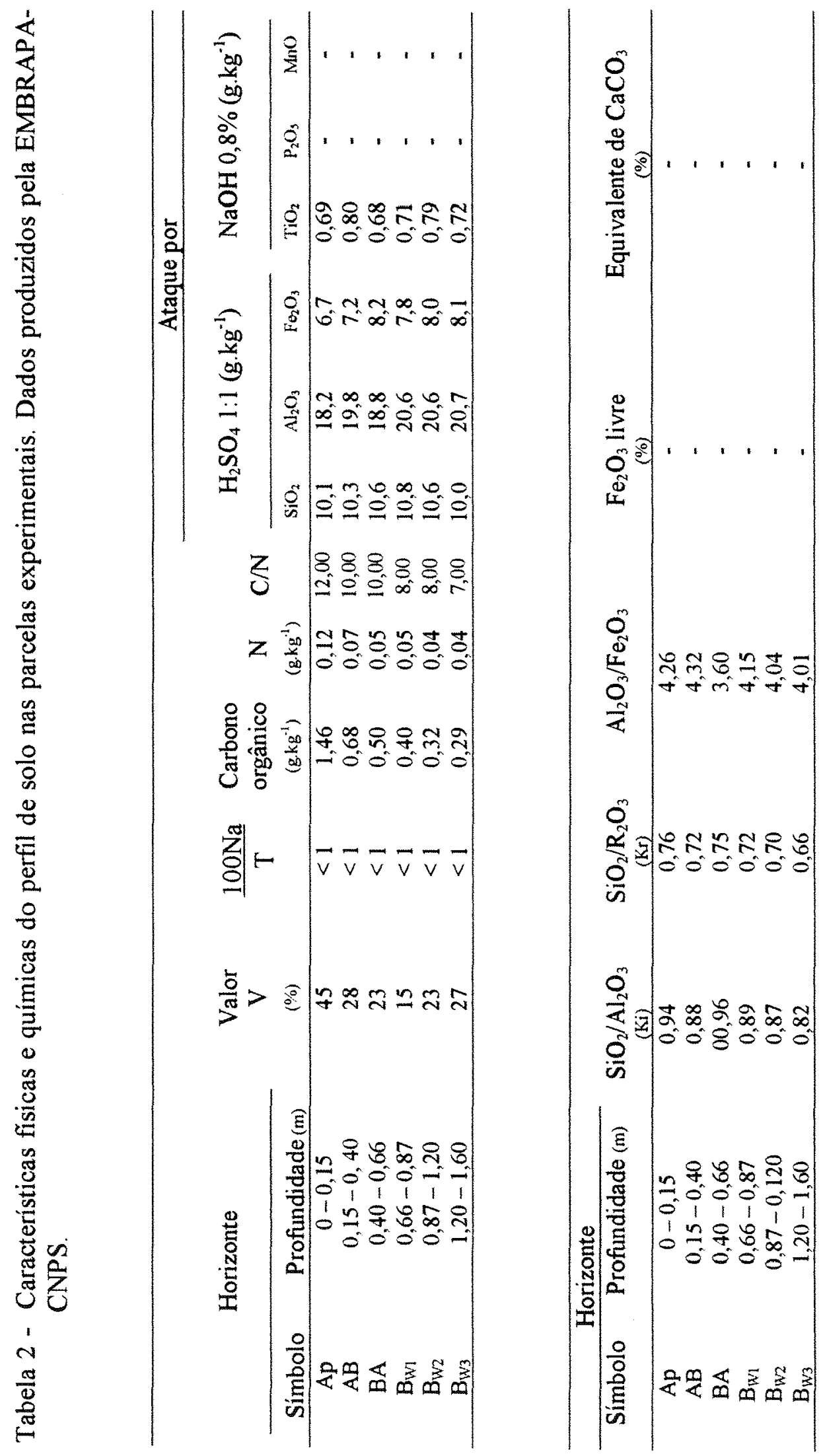
Essa característica evidenciada, é mais nitida na metade sul do estado, em que se alternam um período seco de inverno-primavera e um período chuvoso de verão-outono que concentra cerca de $70 \%$ dos totais de chuva. Na metade norte, o período seco diminui gradualmente atingindo dois meses (junho e julho) no extremo NW do Estado (Nimer \& Brandão, 1989). Apresenta ainda, umidade relativa média anual do ar igual a $80 \%$. A evapotranspiração potencial (EP), sobre as chapadas e as serras de Mato Grosso é, em geral, inferior a $1.140 \mathrm{~mm}^{-a n 0^{-1}}$, podendo cair para valores inferiores a 997,0 mm.ano ${ }^{-1}$, em virtude de baixas temperaturas. A evapotranspiração real, resultante do cotejo entre a EP e a chuva ocorrida, é maior na primavera-verão, em função das temperaturas mais elevadas nesses periodos. Segundo critérios de classificação proposto por Wilhelm Köppen (Köppen, 1948), o clima é do tipo transição Cwa - Cwb (C: zona climática temperado chuvoso; w: temperado úmido com inverno seco; $a$ : subtropical e b: tropical).

\subsection{Delineamento experimental}

\subsubsection{Preparo do solo e semeadura}

No preparo do solo foi efetuado subsolagem para descompactação, seguida de uma aração e duas gradagens. A correção e adubação do solo foi executada em acordo com a análise química (350 kg.ha ${ }^{-1}$ na formulação 4-20-20). Utilizou-se programa de controle de ervas daninhas com os produtos Herbadox $\mathrm{CE}$, pré-emergente, 3,5 litros de ingrediente ativo (Pendimethalin).ha ${ }^{-1}$ e Blazina SC, pós-emergente, 8,0 litros de ingrediente ativo (Cyanazine + Simazine) $\cdot \mathrm{ha}^{-1}$. Periodicamente após a instalação do ensaio foram efetuadas inspeções no local, para observação da ocorrência de plantas daninhas, pragas, doenças e devidos controles bem como tratos culturais necessários às parcelas experimentais.

A semeadura foi efetuada em 04/07/97. O experimento constitui-se de 5 repetições, 4 materiais genéticos de milho submetidos a 8 niveis de estresse hídrico $\left(\mathrm{NEH}_{1-8}\right)$, perfazendo um total de 160 parcelas experimentais. O esquema mostrando a disposição das parcelas com informações complementares e o arranjo de cada tratamento é mostrado na Figura 1. 


\begin{tabular}{|c|c|c|c|c|c|c|c|c|c|}
\hline \multirow{4}{*}{\begin{tabular}{l}
0 \\
$\delta$ \\
\hdashline
\end{tabular}} & $\vec{\Sigma}$ & $\bar{\Sigma}$ & $\sum$ & $\Sigma$ & $\bar{\Sigma}$ & $\sum$ & $\sum$ & $\sum$ & \multirow{4}{*}{ 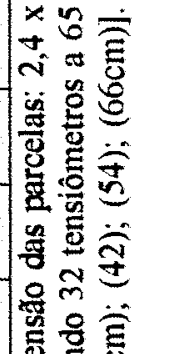 } \\
\hline & $\sum$ & $\vec{\Sigma}$ & $\vec{\Sigma}$ & $\sum$ & $\sum$ & $\frac{\pi}{2}$ & $\frac{\vec{Z}}{2}$ & $\sum_{\Sigma}^{\mathbb{L}}$ & \\
\hline & $\stackrel{\overrightarrow{2}}{\Sigma}$ & $\bar{z}$ & $\bar{\Sigma}$ & $\bar{\Sigma}$ & $\Sigma$ & $\sum$ & $\bar{\Sigma}$ & $\sum$ & \\
\hline & $\Sigma$ & $\tilde{\Sigma}$ & $\Sigma$ & $\stackrel{*}{\Sigma}$ & $\Sigma$ & $\vec{z}$ & $\Sigma$ & $\Sigma$ & \\
\hline \multirow{4}{*}{$\sum_{\substack{e \\
e}}$} & $\bar{\Sigma}$ & $\sum^{n}$ & $\Sigma$ & $\sum^{m}$ & $\tilde{\Sigma}$ & $\sum$ & $\sum_{\Sigma}^{m}$ & $\tilde{\Sigma}$ & \multirow{8}{*}{ 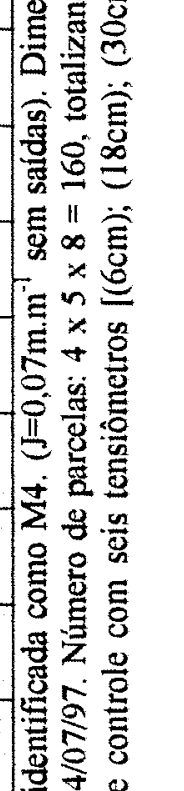 } \\
\hline & $\tilde{\Sigma}$ & $\bar{\Sigma}$ & $\sum$ & $\Sigma$ & $\sum$ & 芝 & $\stackrel{ \pm}{\Sigma}$ & $\sum$ & \\
\hline & $\tilde{\Sigma}$ & $\sum_{\Sigma}^{ \pm}$ & $\bar{\Sigma}$ & $\sum_{\Sigma}^{ \pm}$ & $\bar{\Sigma}$ & $\vec{z}$ & $\vec{\Sigma}$ & 芝 & \\
\hline & ${ }_{\Sigma}^{*}$ & $\Sigma$ & $\vec{\Sigma}$ & $\bar{\Sigma}$ & $\sum_{\Sigma}^{+}$ & $\tilde{\Sigma}$ & $\tilde{\Sigma}$ & $\vec{\Sigma}$ & \\
\hline \multirow{4}{*}{$\frac{8}{8}=$} & $\vec{\Sigma}$ & $\sum$ & $\sum$ & $\sum_{\Sigma}^{+}$ & $\sum$ & $\sum$ & $\sum$ & $\sum^{m}$ & \\
\hline & $\sum_{z}^{n}$ & $\sum$ & $\vec{\Sigma}$ & $\bar{\Sigma}$ & $\vec{\Sigma}$ & $\vec{z}$ & $\bar{\Sigma}$ & $\vec{\Sigma}$ & \\
\hline & $\vec{\Sigma}$ & $\vec{z}$ & $\sum$ & $\sum_{\Sigma}^{\tilde{z}}$ & $\vec{\Sigma}$ & $\stackrel{\sigma}{2}$ & $\sum_{\Sigma}^{*}$ & $\sum$ & \\
\hline & $\Sigma$ & $\sum$ & $\sum$ & $\sum$ & $\tilde{\Sigma}$ & $\sum$ & $\Sigma$ & $\frac{\pi}{z}$ & \\
\hline \multirow{4}{*}{ 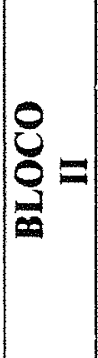 } & $\sum_{\Sigma}^{m}$ & $\sum_{\Sigma}^{m}$ & $\Sigma$ & $\sum_{\Sigma}^{\tilde{n}}$ & $\Sigma$ & $\sum$ & $\sum_{\Sigma}^{m}$ & $\sum$ & \multirow{9}{*}{ 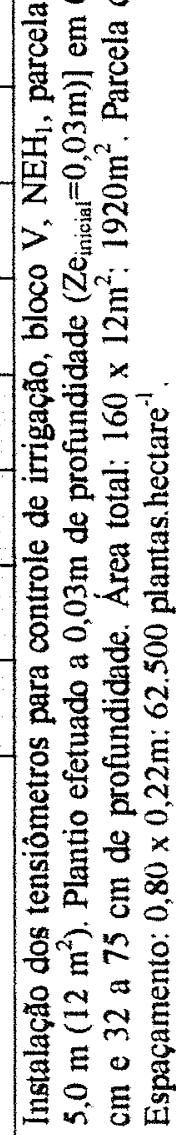 } \\
\hline & 芝 & $\bar{\Sigma}$ & $\bar{\Sigma}$ & $\vec{\Sigma}$ & $\vec{\Sigma}$ & 芝 & $\bar{\Sigma}$ & $\sum$ & \\
\hline & $\vec{\Sigma}$ & $\sum$ & $\underset{\Sigma}{ \pm}$ & $\vec{\Sigma}$ & $\bar{\Sigma}$ & $\Sigma$ & $\sum_{\Sigma}^{ \pm}$ & $\tilde{\Sigma}$ & \\
\hline & $\tilde{\Sigma}$ & $\stackrel{\tilde{z}}{\Sigma}$ & $\sum$ & $\tilde{\Sigma}$ & $\tilde{\Sigma}$ & $\bar{\Sigma}$ & $\stackrel{\Sigma}{\Sigma}$ & $\sum_{\Sigma}^{*}$ & \\
\hline \multirow{4}{*}{ 要 } & $\bar{\Sigma}$ & $\bar{\Sigma}$ & $\Sigma$ & $\sum$ & $\tilde{\Sigma}$ & $\stackrel{m}{2}$ & $\Sigma$ & $\sum_{\Sigma}^{J}$ & \\
\hline & $\sum$ & $\sum$ & $\sum$ & $\Sigma$ & $\Sigma$ & $\sum$ & $\sum_{\Sigma}^{+}$ & $\sum$ & \\
\hline & $\vec{\Sigma}$ & $\vec{z}$ & $\vec{\Sigma}$ & $\Sigma$ & $\bar{\Sigma}$ & $\sum$ & $\Sigma$ & $\vec{\Sigma}$ & \\
\hline & $\Sigma$ & $\sum$ & $\sum_{\Sigma}^{J}$ & $\vec{\Sigma}$ & 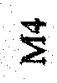 & 这 & $\Sigma$ & 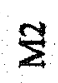 & \\
\hline 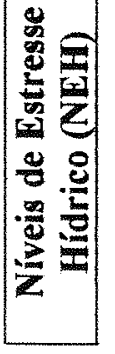 & $\overrightarrow{\dot{1}}$ & 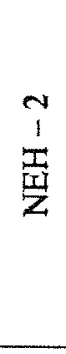 & 昰 & $\frac{1}{\frac{1}{z}}$ & 㽦 & $\frac{1}{\mathrm{I}}$ & $\frac{1}{\frac{1}{2}}$ & $\begin{array}{l}\infty \\
1 \\
1 \\
\text { 豈 } \\
\text { Z }\end{array}$ & \\
\hline
\end{tabular}


As características agronômicas dos materiais superprecoce de milho utilizados no experimento, estão sumariadas na Tabela 3. Os materiais aqui utilizados são oriundos de ensaios estaduais (EE) após o segundo ano de avaliação, com desempenho igual ou superior a média dos EE menos seu desvio padrão.

Tabela 3 - Características dos materiais de milho superprecoce, utilizados nos estudos de balanço hídrico a nível de campo que apresentaram interação genótipoambiente.

\begin{tabular}{cccc}
\hline Material & & & \\
Genético & Empresa & Base Genética & Tipo de Grão \\
\hline AG 9012 & Agroceres & Hibrido Simples & Duro vermelhado \\
AG 9014 & Agroceres & Hibrido Simples Modificado & Duro vermelhado \\
C 806 & Cargill & Hibrido Triplo & Semiduro amarelo laranjado \\
Z 8392 & Zeneca & Hibrido Simples & Semiduro laranjado \\
\hline
\end{tabular}

\subsubsection{Modelo estatístico}

O delineamento experimental utilizado foi o de blocos casualizados com parcelas subdivididas (split plot), em 5 repetições, eq. (1).

$$
\begin{aligned}
& y_{i j k}=\mu+t_{i}+b_{j}+(t b)_{i j}+t^{\prime}{ }_{k}+\left(t t^{\prime}\right)+e_{i j k} \\
& \text { com i }=1,2, \ldots, \mathrm{I} ; \mathrm{j}=1,2, \ldots, \mathrm{J} \mathrm{e} \mathrm{k}=1,2, \ldots, \mathrm{k}
\end{aligned}
$$

em que:

$\mathrm{Y}_{\mathrm{ijk}}$ : valor observado correspondente a combinação do tratamento principal $\mathrm{i}$ com o tratamento secundário $k$ no bloco $j$;

$\mu$ : constante;

$t_{i}$ : efeito do tratamento principal $i$

$b_{j}$ : efeito do bloco j;

$(\text { tb })_{\mathrm{ij}}$ : efeito da interação do tratamento principal $i$ com o bloco $j$, é usada como resíduo a nível de parcelas, definida como RESÍDUO $(A)$;

$\mathrm{t}_{\mathrm{k}}$ : efeito do tratamento secundário $k$;

$\left(\mathrm{tt}^{\prime}\right)_{\mathrm{ik}}$ efeito da interação do tratamento principal i com o tratamento secundário $k$ $\mathrm{e}$;

$\mathrm{e}_{\mathrm{ijk}}$ erro experimental associado a $\mathrm{y}_{\mathrm{ijk}}$, usado como resíduo a nível de subparcelas, definido como RESIDUO (B).

Os tratamentos, principal e secundário referem-se aos materiais de milho e aos níveis de estresse hídrico, respectivamente. Cada parcela foi constituída de 3 linhas de 
plantas com 5 metros de comprimento sendo, a linha central a parcela útil e, duas linhas laterais referente à bordadura do experimento, tendo cada parcela uma área útil de 12 $\mathrm{m}^{2}$, perfazendo $1.920 \mathrm{~m}^{2}$. Assumiu-se espaçamento entre fileiras igual a $0,80 \mathrm{~m}$, com 78 sementes a cada $10 \mathrm{~m}$ de linha de plantio, o que permitiu posterior desbaste ( 28 dias após a semeadura). Após o estabelecimento das plantas, obteve-se estande final de 62.500 plantas. ha ${ }^{-1}$.

\subsubsection{Sistema de aplicação de água}

A água foi aplicada por um sistema de aspersão em linha utilizando-se aspersor rotativo marca NAAN modelo 233 , bocais $4,4 \times 2,5 \mathrm{~mm}$, pressão de operação igual a 350 $\mathrm{kPa}$ com padrão triangular de distribuição de água, Figura 2. Este, quando comparado a outros modelos atualmente disponiveis mostrou-se mais adequado às características da técnica de aspersão em linha (Oliveira et al., 1997a).

A quantidade de água aplicada às plantas foi estimada conforme eq. (2). A reposição de água, via irrigação em todas as parcelas, teve como limite superior a capacidade de água disponível (CAD), até o completo estabelecimento da cultura junto às parcelas experimentais (assumido quando $50 \%$ das plantas apresentarem-se 4 folhas com o limbo completamente estendido a partir da lígula).

$$
\mathrm{CAD}_{\mathrm{n}} \cong 10 \cdot\left(\theta_{\mathrm{CC}}-\theta_{\mathrm{PMP}}\right) \cdot \mathrm{Z \textrm {e } _ { \mathrm { n } }} \cdot \mathrm{Fd}
$$

em que:

$\theta_{C C:}$ umidade na capacidade de campo expresso em base volume $\left(\mathrm{m}^{3} \cdot \mathrm{m}^{-3}\right)$;

$\theta_{P M P}$ : umidade expressa em base volume $\left(\mathrm{m}^{3} \cdot \mathrm{m}^{-3}\right)$, para tensão correspondente a $150 \mathrm{MPa}$;

$Z e_{n}$ : profundidade efetiva do sistema radicular (m) no n-ésimo periodo e;

O fator de depleção $(\mathrm{Fd})$, correspondente a fração da CAD na qual a condição evapotranspiração real (ETr) mantém-se igual a evapotranspiração máxima (ETm), (Doorenbos \& Kassam, 1979), por razões de praticidade utilizou-se eq. (3), cujo $\mathrm{R}^{2}$ corresponde a 0,9840 .

$$
F d=1,0454 . \exp ^{(-0.1015765 E T m)}
$$



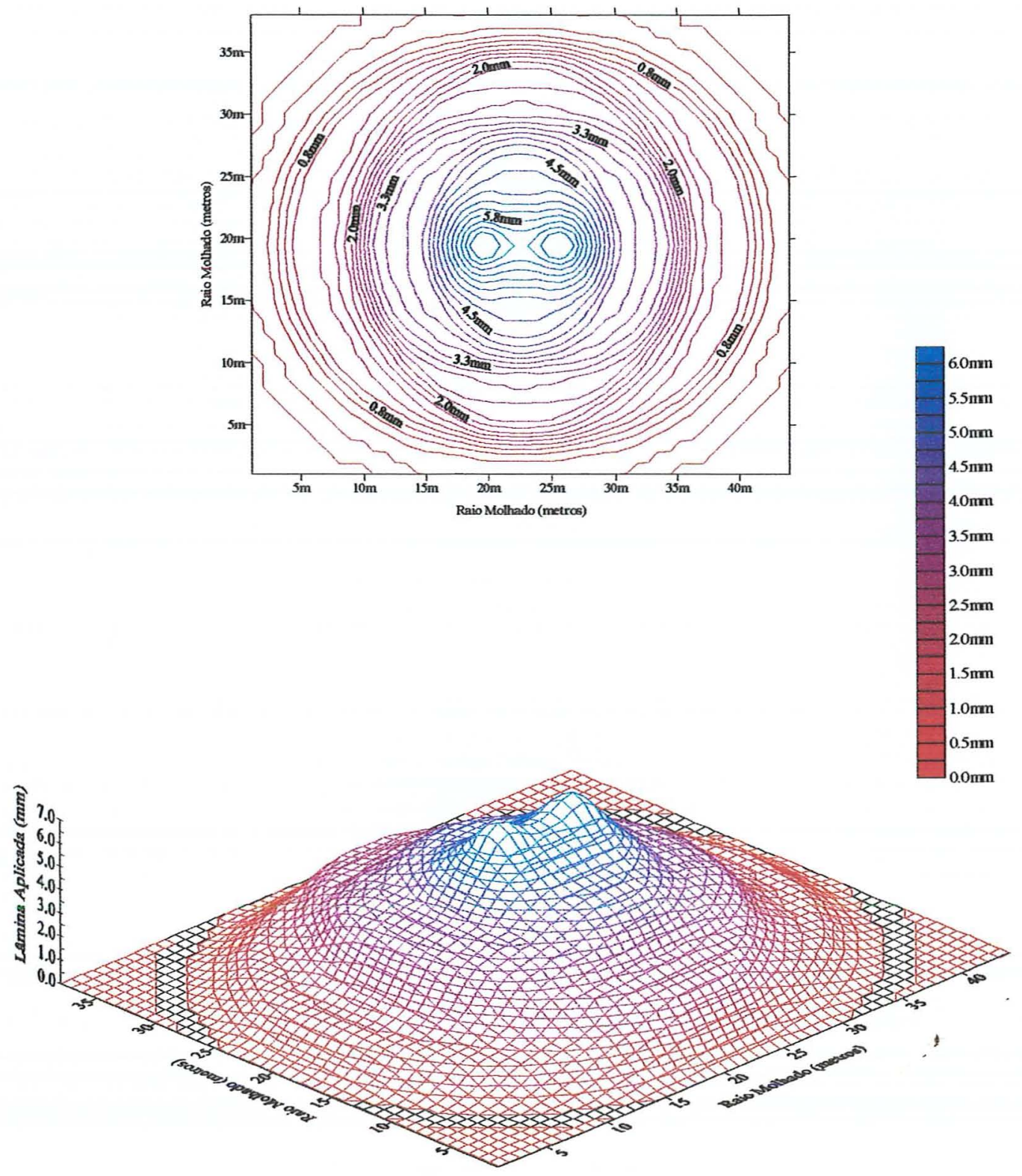

Figura 2 - Padrão de distribuição de água em dois aspersores rotativos NAAN modelo 233 , espaçados em $6,0 \mathrm{~m}$ com bocais $4,4 \times 2,5 \mathrm{~mm}$. Intensidade média de aplicação de água igual a $1,9 \mathrm{~mm} \cdot \mathrm{h}^{-1}$, vazão correspondente a $1,93 \mathrm{~m}^{3} \cdot \mathrm{h}^{-1}$. No ensaio de laboratório a correlação entre lâmina média $(\mathrm{Y})$ e raio molhado (X) seguiu modelo linear: $\mathrm{Y}=2,027-0,108 \mathrm{X}, \mathrm{R}^{2}=0,9522$ com significância $(\alpha)<1 \%$. 
A umidade na capacidade de campo foi assumida como o ponto de inflexão da curva característica de umidade do solo, ajustada segundo modelo proposto por Genuchten (1980), eq. (4). Nesta equação, os valores de m e de outros parâmetros, foram estimados através da análise de regressão não linear (Dourado Neto et al., 1990). Os valores, para intervalos de $0,1 \mathrm{~m}$ no perfil do solo das parcelas experimentais, são mostrados no Anexo E.

A profundidade do sistema radicular $\mathrm{Ze}_{\mathrm{n}}$, foi estimada por uma função tipo sigmoidal, eq. (5) e eq. (6). Considerou-se $\mathrm{Ze}_{(\text {(inicial) }}$ igual a $0,03 \mathrm{~m}, \mathrm{Ze} \mathrm{e}_{\text {(máximo) }}$ igual a $0,70 \mathrm{~m}$ e o fator de forma da curva de crescimento do sistema radicular para o milho assumiu valor igual a 0,974 (Garcia et al., 1997).

$$
\theta_{\mathrm{inf}}=\theta_{r}+\left(\theta_{s}-\theta_{r}\right)\left(\frac{m}{m+1}\right)^{m}
$$

em que:

$\theta_{\text {inf }}:$ umidade $\left(\mathrm{m}^{3} \cdot \mathrm{m}^{-3}\right)$ correspondente ao ponto de inflexão;

$\theta_{r}:$ umidade residual $\left(\mathrm{m}^{3} \cdot \mathrm{m}^{-3}\right)$;

Os: : umidade de saturação $\left(\mathrm{m}^{3} \cdot \mathrm{m}^{-3}\right) \mathrm{e}$;

$m$ : parâmetro empírico do modelo.

$$
\begin{aligned}
& Z e_{n}=Z e_{i n i}+\left(\frac{Z e_{\max }-Z e_{i n i}}{2}\right)\left[1-\cos \left(\pi^{1 / f} \cdot \frac{G D i}{G D T}\right)^{f}\right](\text { se GDi<GDT) } \\
& Z e_{n}=Z e_{\max } \text { se } \mathrm{d} \geq \mathrm{D} \text { (condicionado a } 1040^{\circ} \mathrm{C} \cdot \text { dia } ; Z \mathrm{e}_{\mathrm{n}}=Z \text { e máximo) }
\end{aligned}
$$

em que:

$Z e_{i n i}:$ valor inicial da profundidade efetiva do sistema radicular,

$Z e_{\text {max }}$ : profundidade máxima efetiva do sistema radicular;

$G D i$ : ${ }^{\circ} \mathrm{C}$. dia acumulado no e-nésimo dia " $\mathrm{i}$ ";

$G D t$ : total de ${ }^{\circ} \mathrm{C}$.dia acumulado para todo o ciclo da cultura e;

$f:$ fator de forma do crescimento radicular.

Tomou-se como critério para a determinação do momento de irrigar, toda vez que o consumo de água na parcela de controle atingisse o limite inferior de água 
armazenada para as plantas de milho nos diferentes períodos de desenvolvimento $\left(\theta_{\text {critico }}\right)$, eq. (7).

$$
\theta_{\text {critioc }}=\left[\left[\bar{\theta}_{C C}-\bar{\theta}_{P M P}\right) Z e n\right]-\left\lfloor\left(\bar{\theta}_{C C}-\bar{\theta}_{P M P}\right) Z e n F d\right\rfloor+\bar{\theta}_{P M P}
$$

O monitoramento do decréscimo da lâmina de água armazenada nas parcelas experimentais, deu-se por uma bateria de seis tensiômetros devidamente instalados na parcela de controle e, pelo balanço diário da evapotranspiração máxima da cultura do milho com base no evaporímetro de piche e na temperatura. Assim, o momento de irrigação era sempre correspondente ao momento em que um dos controles identificassem consumo de água na parcela de controle (parcela essa, situada a partir da tubulação onde as demais, em função do gradiente, tiveram déficits hídricos cumulativos ao longo do ciclo das plantas). Portanto, o regime hídrico no perfil oscilou entre a quantidade prontamente disponivel às plantas $(F d . C A D)$ e o armazenamento crítico [(1$F($ d).CAD]. A quantificação instantânea do conteúdo de água no solo utilizando a técnica da tensiômetria se deu indiretamente pela leitura do potencial mátrico da solução do solo, eq. (8) e eq. (9).

$$
\begin{aligned}
& \psi_{m}=-12,6 h_{H g}+h_{\text {solo }}+Z \\
& \theta_{i}=\theta_{r}+\left(\theta_{s}-\theta_{r}\right)\left[I+\left(\alpha \cdot \psi_{m}\right)^{n}\right]^{-m}
\end{aligned}
$$

em que:

$\psi_{m}$ : potencial mátrico da solução do solo;

$h_{H g}$ : altura da coluna de mercúrio lida no tensiômetro;

$h_{\text {solo }}$ :altura do nivel de mercúrio em relação à superficie do solo;

$Z$ : profundidade de medida.

Or: umidade residual $\mathrm{m}^{3} \cdot \mathrm{m}^{-3}$;

As: umidade correspondente à saturação $\mathrm{m}^{3} \cdot \mathrm{m}^{-3}, \mathrm{e}$

$\alpha$ : expresso $\mathrm{em} \mathrm{m}^{-1} ; m$ e $n$. referem-se aos parâmetros empiricos do modelo.

Na parcela experimental de controle havia uma transeção sentido longitudinal à linha de plantio referente à área útil com seis tensiômetros espaçados e instalados em profundidades eqüidistantes. Paralelo a esses pontos, utilizando trado volumétrico de 
percusão, coletou-se amostras indeformadas de solos para estimativa do conteúdo de água antes e após as irrigações, tomando-se medidas do potencial mátrico $\left(\psi_{m}\right)$ nas profundidades de instalação dos tensiômetros.

A estimativa do consumo de água com base no evaporímetro de piche e temperatura se deu pela eq. (10). Essa, derivada da equação original de estimativa da evapotranspiração de referência ETo proposta por Linacre, foi devidamente ajustada para às condições locais apresentando alto coeficiente de determinação quando comparada com medidas diretas de ETo (Campelo Júnior \& Caseiro, 1989).

$$
\mathrm{ET}_{\mathrm{m}}=\left[\frac{\lambda \cdot \mathrm{Fc} \cdot \frac{\mathrm{T}+0,006 \cdot \mathrm{H}}{(100-\mathrm{A})}}{80-\mathrm{T}}+(40-\mathrm{T}) \cdot \mathrm{Pi}\right] \mathrm{K} c
$$

em que:

$E T_{m}$ : evapotranspiração máxima observada na cultura do milho, $\mathrm{mm}$;

$\lambda$ : constante igual a 500 para superficies vegetadas e 700 para superficies com água livre;

$F c$ : fator de correção correspondente à fração $N / 12$ onde $N$ corresponde ao número de horas máximo de insolação possível para o dia central do decêndio;

$T$ : temperatura média do ar $\left({ }^{\circ} \mathrm{C}\right)$;

$H:$ altitude local, em metros (780);

$A$ : latitude do local, em graus (módulo) e;

$P i$ : leitura efetuada no evaporímetro de Piche, em $\mathrm{mm}$.

Utilizou-se coeficientes de cultura $(\mathrm{Kc})$ na estimativa de ETm para a cultura do milho, conforme descrito em (Doorenbos \& Kassam, 1979).

\subsection{Balanço hídrico}

Foi efetuado a campo, nas parcelas experimentais determinando cada componente da eq. (10).

$$
\int_{0}^{z} \int_{t_{1}}^{t_{2}} \frac{\partial \theta}{\partial t} d t d z=\int_{t_{1}}^{t_{2}} p d t+\int_{t_{1}}^{t_{2}} i d t \pm \int_{t_{1}}^{t_{2}} q d t-\int_{t_{2}}^{t_{2}} e d t-\int_{t_{1}}^{t_{2}} t d t \pm \int_{t_{1}}^{t_{2}} r d t
$$

em que: 
$\theta:$ conteúdo de água do solo expressos em $\left(\mathrm{m}^{3} \cdot \mathrm{m}^{-3}\right) ;$

$p$ : precipitação pluviométrica;

$i$ : água aplicada às parcelas por irrigação;

$q$ : fluxo ascendente (ascenção capilar) e descendente (drenagem profunda),

$e$ : volume de água transferido à atmosfera pelos processos de evaporação;

$t$ : volume de água transferido à atmosfera pelos processos de transpiração das plantas e;

$r$ : escoamento.

As precipitações pluviométricas foram medidas por pluviômetros instalados junto às parcelas experimentais. Os fluxos verticais (ascendente e descendente) foram estimados segundo equação proposta originalmente por Darcy-Buckinghan (Libardi, 1995). O escoamento superficial (r) foi assumido como igual a zero, (desprezível).

Os termos da eq. (11), edt e $t d t$ em solos cultivados são considerados em conjunto, designando o processo de evapotranspiração. Geralmente esses termos, exceto os termos referentes à evapotranspiração, podem ser medidos ou estimados e, por diferença obtém-se os valores de $e d t+t d t$ (Etdt). Com algumas aproximações de contorno a eq. (11), reduz-se a eq. (12).

$$
\int_{\mathrm{tl}}^{\mathrm{t} 2} E t d t=\int_{\mathrm{t}}^{\mathrm{l}} \int_{0}^{\mathrm{t}}\left(\frac{\partial \mathrm{q}}{\partial \mathrm{z}}\right) d z d t \cong \Delta_{\text {ARMATENAMENTO }}=p+i \pm q \pm R-E T
$$

A quantificação dos fluxos verticais devido a drenagem interna e/ou ascenção capilar na extremidade abaixo da superficie do solo, considerado para o instante $i$ numa profundidade $Z_{e i}$, eq. (5 e 6), foi quantificada segundo a equação de Darcy-Buckingham para meios isotrópicos não saturados, eq. (13).

$$
q_{z}=-K_{(\theta)} \frac{\partial \psi_{i}}{\partial z} \cong-K_{(\theta)} \frac{\partial \psi_{m}+\psi_{z}}{\partial z} \cong-K_{(\theta)} \frac{\Delta \psi_{m}+\psi_{z}}{\Delta z}
$$

em que:

$q_{z}$ : densidade de fluxo de água no perfil de solo;

$k_{(\theta)}$ : condutividade hidráulica não saturada solo;

$\partial \psi_{t} / \partial z$ : gradiente unitário de potencial total; 
$\psi_{i}$. potencial total da solução no solo;

$\psi_{m}$ : potencial mátrico da solução do solo;

$\psi_{z}$ : potencial de posição da solução no solo e;

$z$ : coordenada vertical de posição.

Genuchten (1985), pelo método de minimização dos quadrados dos desvios, com base na restrição de que $m=1-1 / n$, combinou a equação de ajuste $\theta\left(\psi_{\mathrm{m}}\right)$, eq. (9), com o modelo proposto por Mualem (1976) para estimativa da função $K(\theta)$, obtendo uma função derivada, eq. (14) que, indiretamente permitiu conhecer a condutividade hidráulica do solo para qualquer umidade ( $\theta \mathrm{i})$. O parâmetro de ajuste $m$, assim definido, possibilita usar a teoria de Mualem no cálculo da condutividade hidráulica a partir dos parâmetros da curva característica de umidade do solo. Os parâmetros do modelo foram obtidos utilizando-se o programa de ajuste de curvas de retenção (Dourado Neto et al., 1990), a partir dos dados observados em laboratório por meio de funil de placa porosa (Funil de Haines ) nas tensões 0,0005; 0,001; 0,006 e 0,01 MPa e câmara de pressão de Richards, nas tensões 0,$03 ; 0,08 ; 0,3$ e 1,5 MPa.

$$
K_{\left(\theta_{i}\right)}=K_{o} \cdot\left[\left(\frac{\theta_{i}-\theta_{r}}{\theta_{s}-\theta_{r}}\right)^{\ell}\right]\left\{1-\left[1-\left(\frac{\theta_{i}-\theta_{r}}{\theta_{s}-\theta_{r}}\right)^{1 / m}\right]^{m}\right\}^{2}
$$

em que:

$k_{\left(\theta_{i}\right)}$ : condutividade hidráulica do solo não saturado, $\mathrm{m} \cdot \mathrm{h}^{-1}$;

$K_{o}$ : condutividade hidráulica do solo saturado, $\mathrm{m} \cdot \mathrm{h}^{-1}$;

$\left(\frac{\theta_{i}-\theta_{r}}{\theta_{s}-\theta_{r}}\right)$ : conteúdo relativo de água no solo e;

$\ell$ : refere-se a um parâmetro empírico do modelo proposto por Mualem, (1976).

A condutividade hidráulica do solo sob condições saturada, foi assumida como igual à velocidade de infiltração básica do solo (VIB), determinada nas parcelas pelo método do infiltrômetro de anel (Bernardo, 1982), igual a 0,023 m. hora ${ }^{-1}$. 
A variação no armazenamento da água no solo foi estimada a partir dos perfis de umidade do solo $\left(\mathrm{m}^{3} \cdot \mathrm{m}^{-3}\right)$, principalmente nas primeiras irrigações após o estabelecimento das plantas. A umidade instantânea foi determinada gravimétricamente para intervalos diferenciados ao longo do ciclo das plantas (de 3 a 17 dias). As amostras retiradas do perfil do solo eram devidamente acondicionadas em recipientes de alumínio com taras previamente determinadas para a determinação do peso úmido $(\mathrm{Pu}) \mathrm{Na}$ separação das fases sólida-líquida (secagem), obedeceu-se o tempo de 48 horas com temperatura constante de $105^{\circ} \mathrm{C}$. Assim, a partir da eq. (15), o peso do solo seco (Ps), fica conhecido estimando-se a umidade atual em base volume.

$$
\theta=\frac{\rho_{\text {glohal }}\left(m_{u}-m_{s}\right)}{m_{s}}
$$

em que:

$\rho_{\text {global: }}$ densidade global do solo, g. $\mathrm{cm}^{-3}$;

$m_{u}$ e $m_{s}$, massa úmida e massa seca do solo em $\mathrm{kg}$, respectivamente.

As constantes hidráulicas do solo, para efeito do cálculo da $\mathrm{CAD}$, para cada instante GDi foram assumidas para três extratos distintos do perfil correspondente ao $\mathrm{Ze}_{\max }$, ficando a CAD estimada conforme eq. (16).

$$
C A D_{(1 / 3)_{i}}=\left[\left(\sum_{Z e_{i}}^{(1 /)_{i} z_{\max }} \theta_{C C} \cdot \frac{1}{3}\right)-\left(\sum_{Z e_{t}}^{\left(\mathrm{I}_{3}\right)_{i} e_{\max }} \theta_{P M P} \cdot \frac{1}{3}\right)\right] F d
$$

\subsection{Graus-dia e parâmetros de desenvolvimento}

Utilizou-se do conceito de graus dia para a caracterização do ciclo das plantas, considerando que o ensaio de avaliação de cultivares foi conduzido em época normal de plantio e os genótipos com resposta positiva ao ambiente foram submetidos ao balanço hídrico no período do inverno, coincidindo com prolongados veranicos e temperaturas reduzidas. Para o cálculo dos graus-dia, utilizou-se o método direto conforme eq. (17).

$$
\left.G D=\sum_{i=1}^{n} \mid\left(T_{\text {maxima }}+T_{\text {minima }}\right) \cdot 1 / 2\right\rfloor-T_{\text {base }}
$$


em que:

GD: soma térmica para determinado dia, $\left({ }^{\circ} \mathrm{C}\right.$.dia);

I: índice que varia do primeiro ao último dia da fase fenológica considerada, da cultura.

$T_{\text {máxima: }}$ temperatura máxima do dia $\left({ }^{\circ} \mathrm{C}\right)$, quando a temperatura máxima ultrapassar $30^{\circ} \mathrm{C}$ consideram-se apenas $30^{\circ} \mathrm{C}$;

$\mathrm{T}_{\text {minima: }}$ temperatura mínima do dia $\left({ }^{\circ} \mathrm{C}\right)$, quando a temperatura mínima for inferior a $10^{\circ} \mathrm{C}$ consideram-se apenas $10^{\circ} \mathrm{C}$;

$\mathrm{T}_{\text {base: }}$ temperatura base $\left({ }^{\circ} \mathrm{C}\right)$, valor assumido $10^{\circ} \mathrm{C}$.

\subsection{1. Índice de área foliar (IAF)}

Quinzenalmente, foram determinados o indice de área foliar (IAF) de cada parcela, dividindo-se o valor medido da área foliar (AF) expresso em $\mathrm{m}^{2}$, pelo espaçamento ocupado pelas plantas $\left(0,90 \mathrm{~m}^{2}\right)$. A área foliar (AF) foi obtida pelo produto de $\mathrm{C} \times \mathrm{L}$, sendo $\mathrm{L}$ o comprimento do limbo sobre a nervura principal desde o ponto de inserção do limbo com a bainha até o ápice da folha e, $\mathrm{C}$ a maior largura perpendicularmente à nervura principal. Esse produto foi corrigido pelo fator de forma igual a $3 / 4$, (Mckee, 1964; Francis et al., 1969), eq. (18);

$$
A F=3 / 4 \cdot \sum_{i=1}^{n}\left(C_{i} \cdot L_{i}\right)
$$

em que:

$n:$ número total de folhas das plantas colhidas na parcela

\subsubsection{Intervalo de florescimento masculino e feminino (IFMF)}

O IFMF assumido foi o intervalo entre o florescimento masculino de $50 \%$ das plantas e a emissão do estilo estigma por $50 \%$ das plantas das parcelas experimentais. Período este expresso pelo total de graus-dia nesse intervalo de tempo, eq. (19).

$$
I F M F=\sum_{i=1}^{n}\left[\left({ }^{o} C . d i a\right)_{50 \% F F}\right]-\sum_{i=1}^{n}\left[\left({ }^{o} C . d i a\right)_{50 \% F M}\right]
$$

Foram também determinados, a cada 15 dias, a altura das plantas (AP) da parcela útil, dada pela distância em metros, da superficie do solo até a extremidade da última folha "cartucho", e/ou extremidade do pendão. 


\subsubsection{Indice de colheita (IC)}

Separando-se das diversas partes da planta (folhas, colmo, ráquis + brácteas e grãos) e acondicionando-as em recipientes de papel perfurado e colocando-as em estufas de circulação forçada de ar a $75^{\circ} \mathrm{C}$, até peso constante, foram obtidos os valores de matéria seca por unidade de área $\left(\mathrm{g} \cdot \mathrm{m}^{-2}\right)$. O IC foi determinado pelo quociente entre a matéria seca dos grãos no ponto de maturidade fisiológica e a fitomassa seca total da planta no ponto de maturidade fisiológica, eq. (20).

$$
I C=\frac{M S G_{(M F)}}{F T_{(M F)}}
$$

em que:

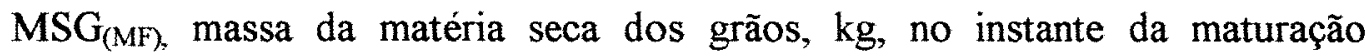
fisiológica e;

$\mathrm{FT}_{(\mathrm{MF})}$, fitomassa total, $\mathrm{kg}$, no instante da maturaçấo fisiológica.

Por ocasião da colheita foram observados: estande final (número de plantas existentes na parcela), número de espigas por parcela e peso dos grãos por parcela, a porcentagem de umidade correspondente a $13,5 \%$ (umidade de armazenamento para grãos de milho).

\subsubsection{Coeficiente de resposta ao estresse hídrico (Ky)}

Foi utilizado o método da zona agroecológica (Doorenbos \& Kassam, 1979) para obtenção do fator de resposta da cultura ao estresse hídrico $(\mathrm{Ky})$, nas condições do ensaio. Considerando-se, para estimativa de $\mathrm{Ky}$, algumas aproximações conceituais em que o rendimento relativo $\left(\mathrm{Yr}_{\mathrm{Y}} \mathrm{Ym}^{-1}\right)$ definido como a razão entre o rendimento referente a cada lâmina (Yr) e rendimento da parcela com reposição total de água $(Y m)$ e, o déficit relativo de água como sendo a razão entre a evapotranspiração real (ETr) e a evapotranspiração máxima $(E T m)$, relacionou-se o rendimento relativo com suprimento relativo de água, obtendo-se o coeficiente de proporcionalidade entre níveis de água no solo e rendimento eq. (21). 


$$
\left.\left(1-\frac{Y r}{Y m}\right)=K y \cdot\left(1-\frac{E T r}{E T m}\right) \therefore K y=\frac{\left[1-\left(Y_{r_{Y m}}\right)\right]}{\left[I-\left(E T_{r} / E T_{m}\right)\right.}\right)
$$

em que:

$Y r_{(N E H)}$, produção média observada nas cinco repetições (blocos) e; $E T r_{(N E H)_{i}}$, evapotranspiração observada nas cinco repetições (blocos).

O somatório do balanço hídrico seqüencial, permitiu comparar o fator demanda evapotranspirativa para cada material genético de milho. Do ponto de vista de consumo hídrico acumulado no ciclo pode-se pressupor materiais mais tolerantes à seca comparativamente à outros.

\subsubsection{Produção de grãos (PG)}

Após a maturação fisiológica das plantas, foi colhida, de cada parcela, a produção de grãos e os resultados convertidos em $\mathrm{kg} \cdot \mathrm{ha}^{-1}$. Para a padronização da umidade entre os tratamentos, inicialmente, determinou-se a umidade dos grãos para cada parcela, em porcentagem, pelas eq. (22) e (23).

$$
\begin{aligned}
& U=\frac{\left(P_{u}-P_{s}\right)}{P_{s}} \cdot 100 \\
& P G_{(U=13,5 \%)}=\left[\frac{\left(P_{u} \cdot 100\right)-\left(P_{u} \cdot U\right)}{86,5 \%}\right]
\end{aligned}
$$

em que:

U: conteúdo de água na amostra de grãos (\%);

$P_{u}$ : peso úmido de uma amostra de grãos $(\mathrm{kg}) \mathrm{e}$;

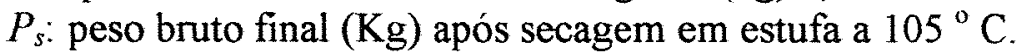




\section{RESULTADOS E DISCUSSÃO}

\subsection{Ciclo da cultura}

A duração dos subperíodos semeadura-maturação fisiológica (S-MF) são mostradas na Tabela 4. Não ocorreram diferenças significativas entre a duração destes e os níveis de estresse hídrico estabelecidos em cada material. A duração média observada foi de 1654,$6 ; 1670,1 ; 1654,6$ e $1654,6^{\circ} \mathrm{C}$.dia nos materiais: C-806; AG-9012; AG-9014 e Z-8392, respectivamente. Entre os níveis de estresse hídrico o $\mathrm{NEH}_{(5)}$ apresentou maior coeficiente de variação (CV) e $\mathrm{NEH}_{(6)}$ o de menor $\mathrm{CV}$ quando comparados aos demais. $\mathrm{O}$ valor médio da duração do subperíodo $\mathrm{S}-\mathrm{MF}$, para as condições deste trabalho pode ser assumido como igual a $1658,5^{\circ} \mathrm{C}$.dia.

Tabela 4 - Duração do subperiodo semeadura-maturação fisiológica (S-MF), observado nos quatro materiais de milho em oito niveis de estresse hidrico. Valores médios por blocos, expressos em ${ }^{\circ} \mathrm{C}$.dia.

\begin{tabular}{|c|c|c|c|c|c|c|c|}
\hline \multirow{2}{*}{$\begin{array}{l}\text { Nível de Estresse } \\
\text { Hídrico (NEH) }\end{array}$} & \multicolumn{7}{|c|}{ Materiais de Milho } \\
\hline & $C=806$ & $A G-9012$ & $A G-9014$ & $Z-8392$ & $\begin{array}{c}\text { Duração } \\
\text { (média) }\end{array}$ & $\begin{array}{c}\text { Desvio } \\
\text { padrão }(\sigma)\end{array}$ & C.V. $(\%)$ \\
\hline 1 & 1655,6 & 1660,1 & 1630,2 & 1632,5 & 1644,6 & 15,4 & 0,94 \\
\hline 2 & 1665,8 & 1700,1 & 1662,7 & 1645,9 & 1688,6 & 22,7 & 1,36 \\
\hline 3 & 1656,7 & 1710,1 & 1670,5 & 1650,9 & 1672,1 & 26,7 & 1,59 \\
\hline 4 & 1662,6 & 1606,2 & 1604,7 & 1625,8 & 1624,8 & 27,0 & 1,66 \\
\hline 5 & 1645,3 & 1698,0 & 1650,6 & 1700,0 & 1673,5 & 29,6 & 1,77 \\
\hline 6 & 1655,6 & 1632,7 & 1632,0 & 1620,0 & 1635,1 & 14,9 & 0,91 \\
\hline 7 & 1642,6 & 1674.1 & 1675,4 & 1670.8 & 1665,7 & 15,5 & 0,93 \\
\hline 8 & 1652,3 & 1679.1 & 1710,4 & 1690.5 & 1683,1 & 24,3 & 1,44 \\
\hline Duração (média) & 1654,6 & 1670,1 & 1654,6 & 1654,6 & 1658,5 & 7,8 & 0,47 \\
\hline Desvio padrão $_{(\sigma)}$ & 7,85 & 35,76 & 32,67 & 29,80 & & & \\
\hline C.V. & 0,47 & 2,14 & 1.97 & 1.80 & & & \\
\hline
\end{tabular}


Analisando as fases fenológicas ou a duração dos subperíodos do desenvolvimento vegetal semeadura-emergência (SE), emergência-florescimento (EF), florescimento-maturação fisiológica (F-MF) e maturação fisiológica-colheita (MF-C), observam-se valores não significativos entre os materiais, Tabela 5.

Tabela 5 - Duração média das fases fenológicas: semeadura-emergência (S-E); emergência-florescimento (E-F); florescimento-maturação fisiológica (FMF) e maturação fisiológica-colheita (MF-C) nos quatro materiais de milho. Valores médios por blocos, expressos em ${ }^{\circ} \mathrm{C}$.dia e, em dias do calendário.

\begin{tabular}{|c|c|c|c|c|}
\hline \multirow{2}{*}{$\begin{array}{l}\text { Materiais } \\
\text { de Milho }\end{array}$} & \multicolumn{4}{|c|}{ Fases Fenológicas } \\
\hline & $S-E$ & $E-F$ & $\mathrm{~F}-\mathrm{MF}$ & MF - C \\
\hline$C-806$ & $\begin{array}{c}63^{\circ} \mathrm{C} \text {.dia } \\
\text { (5 dias) }\end{array}$ & $\begin{array}{c}807^{\circ} \mathrm{C} \cdot \text { dia } \\
\text { (68 dias) }\end{array}$ & $\begin{array}{l}1654^{\circ} \mathrm{C} \cdot \text { dia } \\
\text { (120 dias) }\end{array}$ & $\begin{array}{r}2149^{\circ} \mathrm{C} . \text { dia } \\
\text { (151 dias) }\end{array}$ \\
\hline$A G-9012$ & $\begin{array}{c}63^{\circ} \mathrm{C} \text {.dia } \\
\text { (5 dias) }\end{array}$ & $\begin{array}{c}827^{\circ} \mathrm{C} \text { dia } \\
\text { (69 dias) }\end{array}$ & $\begin{array}{c}1670^{\circ} \mathrm{C} \text {.dia } \\
(121 \text { dias })\end{array}$ & $\begin{array}{c}2149^{\circ} \mathrm{C} . \text { dia } \\
\text { (151 dias) }\end{array}$ \\
\hline$A G-9014$ & $\begin{array}{c}63^{\circ} \mathrm{C} . \text { dia } \\
(5 \text { dias })\end{array}$ & $\begin{array}{c}827^{\circ} \mathrm{C} . \text { dia } \\
\text { (69 dias) }\end{array}$ & $\begin{array}{c}1654^{\circ} \mathrm{C} . \mathrm{dia} \\
(120 \text { dias })\end{array}$ & $\begin{array}{c}2149^{\circ} \mathrm{C} . \text { dia } \\
\text { (151 dias) }\end{array}$ \\
\hline$Z-8392$ & $\begin{array}{c}63^{\circ} \mathrm{C} . \mathrm{dia} \\
(5 \mathrm{dias})\end{array}$ & $\begin{array}{c}791^{\circ} \mathrm{C} \text { dia } \\
\text { (67 dias) }\end{array}$ & $\begin{array}{l}1654^{\circ} \mathrm{C} \text {.dia } \\
\text { (120 dias) }\end{array}$ & $\begin{array}{c}2149^{\circ} \mathrm{C} \text { dia } \\
(151 \text { dias })\end{array}$ \\
\hline
\end{tabular}

Esses resultados contrapõem-se àqueles encontrados por Garcia (1993), onde o estresse hídrico causou efeito linear no aumento do subperíodo S-F na cultura do milho, para dados de cinco anos de cultivo, e por Silva (1989), este, estudando a influência do conteúdo de água do solo nas exigências térmicas em três materiais de milho, concluiu que o estresse hídrico promoveu aumento na duração das fases fenológicas, especialmente para níveis de água disponível abaixo de $40 \%$. Para as nossas condições tropicais, a oferta de água às plantas é um fator de considerável limitação à produtividade, e a não influência no ciclo destas, no período semeadura a maturação fisiológica (S-MF) observado, possa estar associada além dos germoplasmas dos materiais utilizados, à forma de registro da observação dos subperíodos, assumido quando $50 \%$ das plantas da parcela útil externassem as características agronômicas consideradas. Observa-se igualdade entre as durações nos subperiodos S-E, E-F e F-MF. Supõe-se que o critério adotado para o registro de cada subperíodo, naturalmente elimine diferenças maiores entre as parcelas de cada material. $O$ final do ciclo da cultura (151 dias ou $2149,6^{\circ} \mathrm{C}$.dia) foi o mesmo para todos os materiais por razão prática, ou seja, no 
propósito de se efetuar a colheita de uma só vez, permitiu-se então que todos materiais ainda a campo, continuassem o processo de secagem natural, os materiais que chegaram à maturação fisiológica primeiro foram oportunizados com um maior tempo de secagem durante o processo de maturação. Portanto, o tempo de oportunidade para acúmulo de matéria seca nos grãos (F-MF) foi semelhante para os quatro materiais utilizados.

Logo após o início da fase reprodutiva, o total de água aplicada foi praticamente devido às irrigações. A distribuição da chuva diária e acumulada (medida em pluviômetro) juntamente com a radiação líquida disponível (estimada com base nas horas de brilho solar) e tensão de vapor d'água na atmosfera (estimado com base nas temperaturas registradas nos termômetros bulbo seco e bulbo úmido) para o período considerado são mostradas na Figura 3.
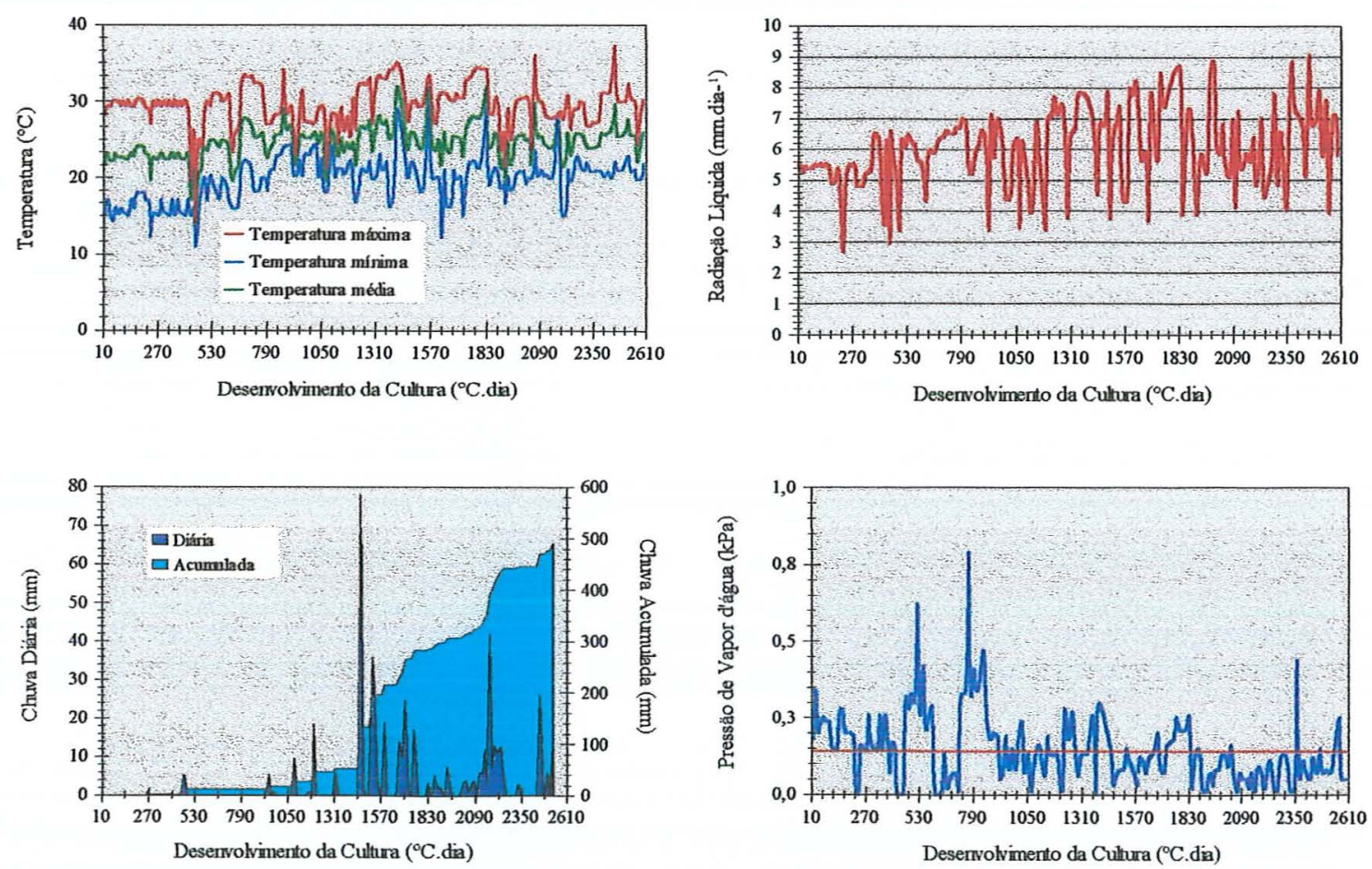

Figura 3 - Distribuição da temperatura máxima, mínima e média $\left({ }^{\circ} \mathrm{C}\right)$; radiação líquida expressa em equivalente de evaporação d' água $(\mathrm{mm})$; chuvas em base diária e acumulada $(\mathrm{mm})$ e, déficit de vapor d'água na atmosfera em base diária com valor médio de $0,14 \mathrm{kPa}$, referentes ao período experimental. 
Evidências experimentais têm mostrado ser a temperatura do ar noturna, como principal elemento meteorológico na duração dos subperíodos para florescimento em milho (Magalhães et. al., 1995). No subperíodo S-MF, as precipitações ocorridas (sempre dispersas) foi possível sua inserção na estimativa das lâminas de água a ser aplicada sem que esta ultrapassasse a capacidade de armazenamento de água do solo.

\subsection{Manejo da irrigação}

A quantidade total de água aplicada às parcelas experimentais foi o somatório das irrigações efetuadas juntamente com as precipitações pluviométricas ocorridas no período. O perfil do solo foi extratificado para elevar a precisão nas inferências de armazenamento e devido às singularidades do horizonte $B_{w 1}$ diante das características hidráulicas de todo o perfil, (Anexo $\mathrm{E}$, extrato 0,50-0,60m). Este apresenta-se com elevada quantidade de $\mathrm{Fe}_{2} \mathrm{O}_{3}$; alta relação $\mathrm{SiO}_{2} / \mathrm{Al}_{2} \mathrm{O}_{3}$ e baixa relação $\mathrm{Al}_{2} \mathrm{O}_{3} / \mathrm{Fe}_{2} \mathrm{O}_{3}$, comparados às demais camadas (Tabela 2). Consideraram-se, então, três extratos no perfil de $0-0,70 \mathrm{~m}\left(\mathrm{Ze}_{\text {máximo }}\right)$ com a capacidade de armazenamento d' água assim distribuidos: $\left.\left.\operatorname{CAD}_{(1)} \mid 0,70 m \cdot(1 / 3)_{i=1}\right\rfloor=1,3 \mathrm{~mm} \cdot \mathrm{cm}^{-1} ; \operatorname{CAD}_{(2)} \mid 0,70 \mathrm{~m} \cdot(1 / 3)_{i=2}\right\rfloor=1,1 \mathrm{~mm} \cdot \mathrm{cm}^{-1}$ e $\operatorname{CAD}_{(3)}\left|0,70 m \cdot(1 / 3)_{i=3}\right|=1,4 \mathrm{~mm} \cdot \mathrm{cm}^{-1}$. As lâminas totais de água estão sumariadas nas Tabelas: 6; 7; 8 e 9. Essas, mostram a integralização das lâminas após o estabelecimento das plantas.

Tabela 6 - Componentes do balanço hídrico e lâminas totais de água (valores médios) aplicada nos diferentes niveis de estresse hídrico $\left(\mathrm{NEH}_{1-8}\right)$ ao longo do ciclo da cultura no material de milho Cargill - 806, periodo (S-MF).

\begin{tabular}{|c|c|c|c|c|c|c|}
\hline \multirow[b]{2}{*}{$\mathrm{NEH}$} & \multirow[b]{2}{*}{$\begin{array}{c}\text { Irrigação } \\
(\mathrm{mm})\end{array}$} & \multirow{2}{*}{$\begin{array}{l}\text { Precipitação } \\
\text { Pluviométrica } \\
\text { (mm) }\end{array}$} & \multicolumn{2}{|c|}{ Fluxo vertical } & \multirow{2}{*}{$\begin{array}{c}\text { Lâmina } \\
\text { total aplicada } \\
(\mathrm{mm})\end{array}$} & \multirow[b]{2}{*}{$\begin{array}{l}\mathrm{ETr} \\
(\mathrm{mm})\end{array}$} \\
\hline & & & $\begin{array}{l}\text { Ascenção } \\
(\mathrm{mm})\end{array}$ & $\begin{array}{c}\text { Drenagem } \\
(\mathbf{m m})\end{array}$ & & \\
\hline 1 & 149,0 & 283,4 & 23,1 & 15,3 & 455,5 & 440,2 \\
\hline 2 & 129,1 & 283,4 & 0 & 7,1 & 412,5 & 405,4 \\
\hline 3 & 115,9 & 283,4 & 9,3 & 5,6 & 408,6 & 402,9 \\
\hline 4 & 95,9 & 283,4 & 0 & 2,1 & 379,4 & 377,3 \\
\hline 5 & 76,0 & 283,4 & 4,6 & 1.2 & 364,0 & 362,8 \\
\hline 6 & 56,1 & 283,4 & 0 & 2,4 & 339,5 & 337,2 \\
\hline 7 & 36,2 & 283,4 & 12,3 & 0,1 & 331,9 & 331,8 \\
\hline 8 & 16.3 & 283,4 & 0 & 11.7 & 299.7 & 288.0 \\
\hline
\end{tabular}


Tabela 7 - Componentes do balanço hídrico e lâminas totais de água (valores médios) aplicada nos diferentes níveis de estresse hídrico $\left(\mathrm{NEH}_{1-8}\right)$ ao longo do ciclo da cultura no material de milho Agroceres - 9012, periodo (S-MF).

\begin{tabular}{ccccccc}
\hline NEH & $\begin{array}{c}\text { Irrigação } \\
(\mathbf{m m})\end{array}$ & $\begin{array}{c}\text { Precipitação } \\
\text { Pluviométrica } \\
(\mathbf{m m})\end{array}$ & $\begin{array}{c}\text { Fluxo vertical } \\
\text { Ascenção } \\
(\mathbf{m m})\end{array}$ & $\begin{array}{c}\text { Drenagem } \\
(\mathbf{m m})\end{array}$ & $\begin{array}{c}\text { Lâmina } \\
\text { total aplicada } \\
(\mathrm{mm})\end{array}$ & $\begin{array}{c}\text { ETr } \\
(\mathbf{m m})\end{array}$ \\
\hline 1 & 149,0 & 283,4 & 57,1 & 0,4 & 489,5 & 489,1 \\
2 & 129,1 & 283,4 & 35,4 & 1,2 & 447,9 & 446,7 \\
3 & 115,9 & 283,4 & 12,6 & 0,8 & 411,9 & 411,0 \\
4 & 95,9 & 283,4 & 17,2 & 0,1 & 396,6 & 396,4 \\
5 & 76,0 & 283,4 & 15,7 & 0 & 375,1 & 375,1 \\
6 & 56,1 & 283,4 & 14,1 & 0,9 & 353,6 & 352,7 \\
7 & 36,2 & 283,4 & 19,6 & 2,4 & 339,2 & 336,8 \\
8 & 16,3 & 283,4 & 13,5 & 0,1 & 313,2 & 313,1 \\
\hline
\end{tabular}

Tabela 8 - Componentes do balanço hídrico e lâminas totais de água (valores médios) aplicada nos diferentes niveis de estresse hídrico $\left(\mathrm{NEH}_{1-8}\right)$ ao longo do ciclo da cultura no material de milho Agroceres - 9014, período (S-MF).

\begin{tabular}{|c|c|c|c|c|c|c|}
\hline \multirow[b]{2}{*}{ NEH } & \multirow[b]{2}{*}{$\begin{array}{l}\text { Irrigação } \\
\text { (mm) }\end{array}$} & \multirow{2}{*}{$\begin{array}{l}\text { Precipitação } \\
\text { Pluviométrica } \\
\text { (mm) }\end{array}$} & \multicolumn{2}{|c|}{ Fluxo vertical } & \multirow{2}{*}{$\begin{array}{c}\text { Lâmina } \\
\text { total aplicada } \\
(\mathrm{mm})\end{array}$} & \multirow[b]{2}{*}{$\begin{array}{l}\text { ETr } \\
(\mathrm{mm})\end{array}$} \\
\hline & & & $\begin{array}{l}\text { Ascenção } \\
\text { (mm) }\end{array}$ & $\begin{array}{l}\text { Drenagem } \\
(\mathrm{mm})\end{array}$ & & \\
\hline 1 & 149,0 & 283,4 & 71,0 & 0 & 503,4 & 503,4 \\
\hline 2 & 129,1 & 283,4 & 21,6 & 1,2 & 434,1 & 432,9 \\
\hline 3 & 115,9 & 283,4 & 25,6 & 3,5 & 429,9 & 421,4 \\
\hline 4 & 95,9 & 283,4 & 22,3 & 4,2 & 401,7 & 397,4 \\
\hline 5 & 76,0 & 283,4 & 27,3 & 3,9 & 386,7 & 382,8 \\
\hline 6 & 56,1 & 283,4 & 25,6 & 7,1 & 365,1 & 358,0 \\
\hline 7 & 36,2 & 283,4 & 28,9 & 6,3 & 348,5 & 342,2 \\
\hline 8 & 16,3 & 283,4 & 21,9 & 5,4 & 321.6 & 316,2 \\
\hline
\end{tabular}

Tabela 9 - Componentes do balanço hídrico e lâminas totais de água (valores médios) aplicada nos diferentes niveis de estresse hídrico $\left(\mathrm{NEH}_{1-8}\right)$ ao longo do ciclo da cultura no material de milho Zeneca - 8392 , periodo (S-MF).

\begin{tabular}{|c|c|c|c|c|c|c|}
\hline \multirow[b]{2}{*}{$\mathrm{NEH}$} & \multirow[b]{2}{*}{$\begin{array}{c}\text { Irrigação } \\
\text { (mm) }\end{array}$} & \multirow{2}{*}{$\begin{array}{l}\text { Precipitação } \\
\text { Pluviométrica } \\
\text { (mm) }\end{array}$} & \multicolumn{2}{|c|}{ Fluxo vertical } & \multirow{2}{*}{$\begin{array}{c}\text { Lâmina } \\
\text { total aplicada } \\
(\mathrm{mm})\end{array}$} & \multirow[b]{2}{*}{$\begin{array}{l}\text { ETr } \\
(\mathbf{m m})\end{array}$} \\
\hline & & & $\begin{array}{l}\text { Ascenção } \\
\text { (mm) }\end{array}$ & $\begin{array}{c}\text { Drenagem } \\
(\mathrm{mm})\end{array}$ & & \\
\hline 1 & 149,0 & 283,4 & 25,3 & 1,2 & 457,7 & 456,5 \\
\hline 2 & 129,1 & 283,4 & 24,1 & 0,1 & 436,6 & 436,5 \\
\hline 3 & 115,9 & 283,4 & 23,3 & 0,9 & 422,6 & 421,7 \\
\hline 4 & 95,9 & 283,4 & 19,4 & 5,1 & 398.8 & 393,7 \\
\hline 5 & 76,0 & 283,4 & 31,6 & 3,2 & 391,0 & 387,8 \\
\hline 6 & 56,1 & 283,4 & 24,6 & 0,1 & 364,1 & 364,0 \\
\hline 7 & 36,2 & 283,4 & 41,7 & 0 & 361.3 & 361,2 \\
\hline 8 & 16,3 & 283,4 & 50,53 & 0 & 350,3 & 350,2 \\
\hline
\end{tabular}

Do total de água evapotranspirada nos quatro materiais, a contribuição da precipitação pluviométrica na condição $\mathrm{NEH}_{8}$ chegou a $98,40 \%$. Esta condição é a mais 
extrema observada, não ocorreram contribuições superiores a 100\% em nenhuma das parcelas o que garantiu um adequado balanço dos fluxos de água em cada parcela experimental. Assim a distribuição das chuvas ocorridas no período experimental, intensidade e duração, permitiu sua inserção no balanço de água no solo subtraindo o exato valor precipitado do total de água aplicado nas irrigações subseqüentes que considerou três extratos do perfil, com a capacidade de água disponível (CAD) efetiva para as plantas, recalculados conforme as variações da profundidade do sistema radicular no e-nésimo dia $\mathrm{i}\left(Z_{\mathrm{en}}\right)$. Tal consideração é válida para os subperíodos semeadura a maturação fisiológica (S-MF). Nota-se que nos $1670{ }^{\circ} \mathrm{C}$.dia, as precipitações pluviométricas ocorridas foram bem distribuídas, sendo que a de máxima intensidade foi da ordem de $13 \mathrm{~mm} \cdot \mathrm{dia}^{-1}$, registrada em pluviógrafo em 30/10/97, correspondente a $1446{ }^{\circ} \mathrm{C}$.dia.

Os fluxos verticais observados foram expressivos, $71,0 \mathrm{~mm}$ de ascenção capilar $\left(\mathrm{NEH}_{1}\right)$ no material $\mathrm{AG}-9014$ e $15,3 \mathrm{~mm}$ de drenagem profunda $\left(\mathrm{NEH}_{1}\right)$ no material $\mathrm{C}$ - 806. Uma contribuição positiva na lâmina total de água aplicada da ordem de $14,10 \%$ de ascenção e $3,36 \%$ de contribuição na água evapotranspirada em conseqüência da drenagem.

Apesar de reduzida, a drenagem tem papel determinante no contexto do balanço hídrico para a estimativa de ETr, não devendo, portanto, neste caso, ser desprezada. Observações mostram que a drenagem, sob condições de latossolo vermelho escuro cultivado com milho, pode chegar a valores de até $67,0 \%$ do total de água consumida (drenagem + evapotranspiração) (Andrade et al., 1988).

À medida em que se consideram as variações temporais do crescimento radicular durante o desenvolvimento do milho, eleva-se a precisão da estimativa da água a aplicar, minimizando em muito as perdas por drenagem profunda. Posto o princípio de fixar uma profundidade única para as raizes do milho as perdas por drenagem tendem a ser expressivas principalmente nos primeiros dias após a semeadura. Souza (1979) observou uma participação da drenagem profunda da ordem de $58,7 \%$ (período úmido) e de $6,6 \%$ (periodo seco) na cultura do feijão, evidenciando que altas perdas pelo fluxo vertical descendente estão associados ao excedente de água no volume instantâneo de 
solo de exploração das raizes das plantas, enfatizando a importância dos fluxos verticais no balanço hídrico no solo. Como se verifica, este componente assume grande importância no balanço hídrico, onde parcelas recebem reposição total de água ao nível da CAD.

O turno de rega (TR), em todo o ciclo, foi variável em função dos critérios adotados para reposição de água às plantas. Observaram-se turnos maiores nos primeiros $500^{\circ} \mathrm{C}$.dia, periodo este coincidente com temperaturas proporcionalmente menores e menor o consumo de água pelas plantas, como relata Denmead \& Shaw, (1962). Tal fato é perceptível na medida em que conceitos dinâmicos de água disponivel no solo para as culturas são considerados no movimento de água no sistema solo-planta-atmosfera, onde o gradiente de potencial da água somada à condutância hidráulica do solo determinam a direção, sentido e dimensão dos fluxos de água. Daí as variações ocorridas nos turnos de rega.

$\mathrm{O}$ total de água consumido pelos materiais de milho em cada condição de NEH, de uma forma geral, mostraram-se significativamente diferentes. A análise entre e dentro dos materiais pode ser observada na Tabela 10.

Tabela 10 - Evapotranspiração real observada nos quatro materiais de milho submetidos à diferentes níveis de estresse hídrico $\left(\mathrm{NEH}_{1-8}\right)$.

\begin{tabular}{|c|c|c|c|c|c|}
\hline \multirow[b]{2}{*}{$\mathrm{NEH}_{(1-8)}$} & \multicolumn{4}{|c|}{ Materiais de Milho } & \multirow[b]{2}{*}{ Médias } \\
\hline & $C-806$ & AG - 9012 & AG - 9014 & $Z-8392$ & \\
\hline 1 & ${ }^{\mathrm{A}} 440,2_{c}$ & ${ }^{\mathrm{A}} 492,3_{\mathrm{a}}$ & ${ }^{A} 488,5_{a b}$ & ${ }^{\mathrm{A}} 456,9_{b c}$ & ${ }^{A} 469,5$ \\
\hline 2 & ${ }^{\mathbf{A B}_{4}} 409, \mathrm{O}_{\mathrm{b}}$ & $\mathbf{A B}_{449,2}$ & $\mathbf{A B}_{426,5}$ & $\mathrm{AB}_{421,9}$ & $\mathrm{AB}_{426,7}$ \\
\hline 3 & $\mathrm{AB}_{400,8}$ & ${ }^{8} 405,3$ & $\mathbf{A B}_{413,4}$ & $\mathrm{AB}_{415,7}$ & $\mathrm{AB}_{408,8}$ \\
\hline 4 & $\mathrm{AB}_{381,5}$ & ${ }^{{ }^{2}} C_{391,6}$ & ${ }_{397,8}$ & $\mathrm{AB}_{401,0 \mathrm{a}}$ & $\mathrm{AB}_{393,0}$ \\
\hline 5 & ${ }_{3}{ }_{347,1_{a}}$ & $\mathrm{BC}_{366,6_{\mathrm{a}}}$ & ${ }^{\mathrm{B}} 380,9_{\mathrm{a}}$ & ${ }^{\mathrm{AB}} 377,4_{\mathrm{a}}$ & ${ }^{\mathbf{B}} 368,0$ \\
\hline 6 & ${ }^{B} 322,6_{a}$ & $\mathrm{BC}_{348,5}$ & $\mathrm{BC}_{329,8}$ & ${ }_{356,5}$ & ${ }_{339,4}$ \\
\hline 7 & ${ }^{8} 310,9$, & $\mathrm{Bc}_{332,0_{\mathrm{ab}}}$ & $\mathrm{BC}_{328,6_{\mathrm{ab}}}$ & $\mathrm{B}_{349,6_{\mathrm{b}}}$ & ${ }_{330,3}$ \\
\hline 8 & ${ }^{8} 269,9 \mathrm{a}$ & $c_{307,8_{b}}$ & $c_{300,5_{\mathrm{bc}}}$ & B $_{345,8_{c}}$ & ${ }_{306,0}$ \\
\hline Médias & $360,2_{b}$ & $386,7 \mathrm{a}$ & $383,3_{\mathrm{a}}$ & $390,6_{z}$ & 380,2 \\
\hline
\end{tabular}

Em cada série de médias na horizontal, os valores seguidos por letras minúsculas distintas diferem entre si ao nível de $5 \%$ de probabilidade pelo teste de Tukey, com D.M.S. igual a $18,6 \mathrm{~mm}$. Em cada série de médias na vertical, os valores seguidos por letras maiúsculas distintas diferem entre si ao nível de $5 \%$ de probabilidade pelo teste de Tukey, com D.M.S. igual a 73,5mm. 
A evapotranspiração real entre materiais de milho não diferiram estatisticamente entre si considerando valor médio de cada material. Entre os níveis de estresse hídrico os valores de água consumida restringiram-se a duas classes de $\mathrm{ETr}$ ao nivel de $5 \%$ de probabilidade. Isto se justifica pelo tamanho utilizado nas parcelas experimentais (largura), que proporciona gradientes menores de aplicação de água entre parcelas. Observa-se que os quatro materiais de milho não diferiram entre si ao nível de

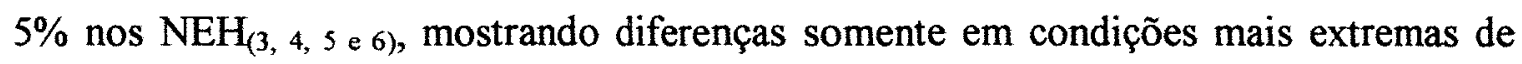
NEH.

\subsection{Indice de área foliar (IAF)}

As análises de variâncias com os testes de significância para todas as variáveis estudadas estão sumariadas no Anexo $\mathrm{F}$. Considerando o IAF integralizado nas medidas observadas em 15/03; 30/08; 14/09; 29/09 e 12/11 em cada material de milho, observouse significância ao nivel de $5 \%$ de probabilidade.

$\mathrm{O}$ índice de área foliar nos materiais C - 806; G - 9012; AG - 9014 e Z - 8392, nos diferentes $\mathrm{NEH}_{(1-8)}$ seguiram um modelo quadrático em função da idade das plantas, com diferenças entre NEH e entre materiais em relação aos coeficientes de determinação $\left(\mathrm{R}^{2}\right)$.

Pelas curvas ajustadas (Figura 4), observa-se que o IAF para todos os $\mathrm{NEH}_{(1-8)}$, nos quatro materiais de milho foi crescente, porém de maneira diferenciada da emergência até cerca de $1300,0^{\circ} \mathrm{C}$.dia, para em seguida decrescerem gradativamente por processos de envelhecimento e senescência. Tal variação, aumento do IAF até um valor máximo no florescimento passando a declinar no período de enchimento de grãos, é típica da cultura do milho, conforme observações de (Tollenaar, 1977); (Sakai, 1996) e (Howell, 1998).

É desejável que a superfície foliar ativa, se considerada como centro de produção de fotoassimilados (fonte), tenha uma maior duração e tamanho, com implicações diretas no rendimento final de grãos. 

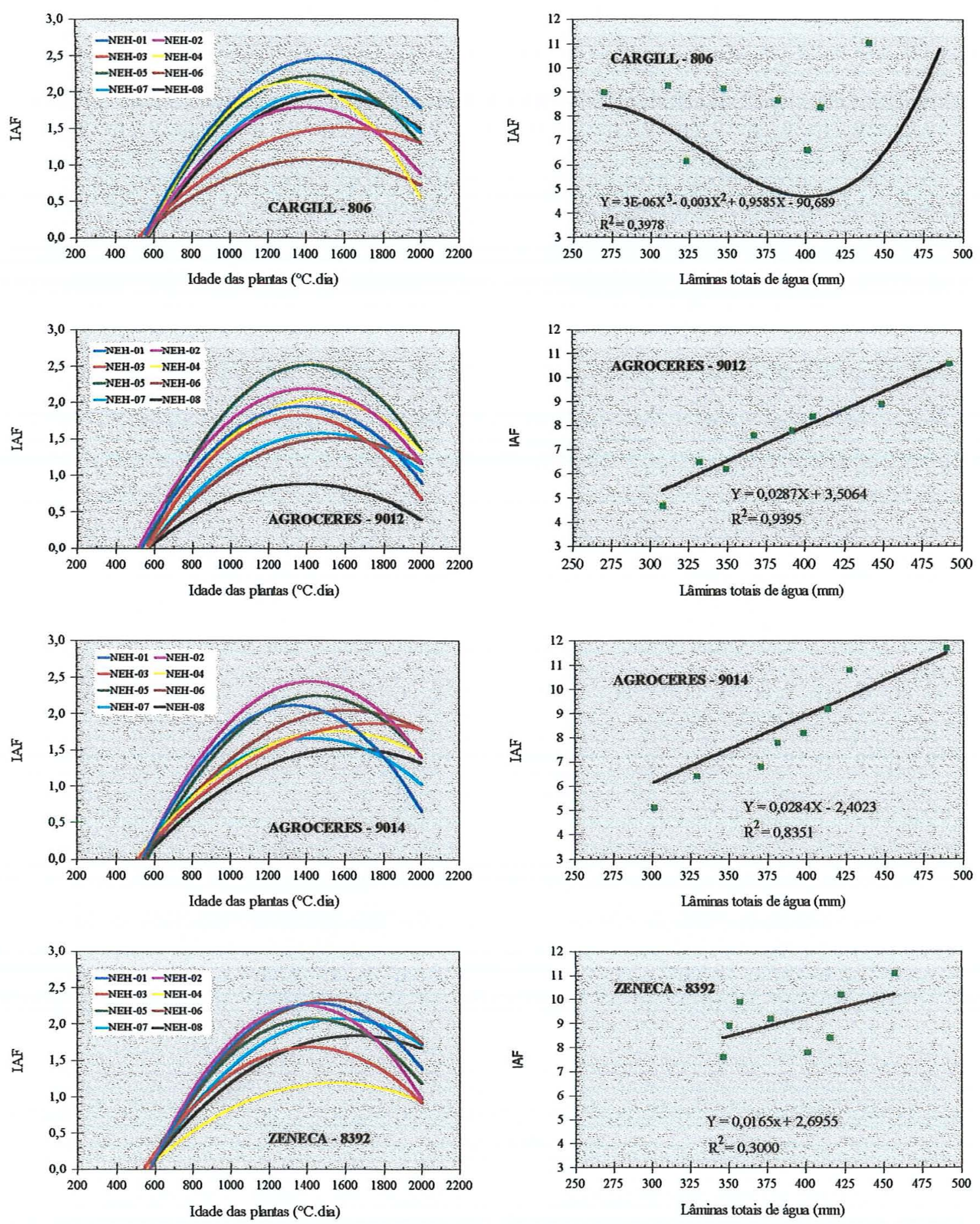

Figura 4 - Índice de área foliar (IAF) ao longo do desenvolvimento das plantas nos materiais C - 806; AG - 9012; AG - 9014 e Z - 8392, em oito diferentes níveis de estresse hídrico $\left(\mathrm{NEH}_{1-8}\right)$. 
No subperíodo F-MF, onde se insere o processo de enchimento de grãos, a duração observada foi praticamente a mesma $\left(812,93^{\circ} \mathrm{C}\right.$ dia a $1658,43^{\circ} \mathrm{C}$ dia), ocorrendo diferenças nas taxas de crescimento e dimensão do IAF entre materiais. O material C806 apresentou maior superficie foliar $\left(\mathrm{IAF} .{ }^{\circ} \mathrm{C}^{-1} \cdot \mathrm{dia}^{-1}\right)$ na fase enchimento de grãos, demostrando, porém, sensibilidade às variações no conteúdo de água no solo (taxa média igual a $0,01 \mathrm{IAF}^{\circ} \mathrm{C}^{-1} \cdot \mathrm{dia}^{-1}$, seguido dos materiais $\mathrm{Z}-8392\left(0,011 \mathrm{IAF}^{\circ} \mathrm{C}^{-1} \cdot \mathrm{dia}^{-1}\right)$, AG-9014 $\left(0,001 \mathrm{IAF}^{\circ} \mathrm{C}^{-1} \cdot \mathrm{dia}^{-1}\right)$ e AG-9012 $\left(0,0009 \mathrm{IAF} .{ }^{\circ} \mathrm{C}^{-1} \cdot \mathrm{dia}^{-1}\right)$

Valores menores no IAF observado dentro de um mesmo material estão associados a maiores estresses hídricos, conseqüência da redução no metabolismo de expansão foliar (Ferreira, 1997 e Hsiao, 1973) e da velocidade do processo de senescência foliar que é mais acelerado após a antese em situações de estresse hídrico (Endres \& Mundstock, 1989).

Apesar de maiores áreas foliares, os materiais Z-8392 e C-806, comparativamente, foram os de menor rendimento de grãos quando se observam valores médios por material. Pressupõe, neste caso, que o tamanho da fonte de fotoassimilados não fora determinante, em mesma proporção, no tamanho e quantidade dos drenos, no caso, os grãos. Maior oferta de fotoassimilados, na fase de enchimento de grãos, redunda em maior rendimento de grãos, quando satisfeitas outras demandas metabólicas e fisiológicas.

Comparando o IAF em cada material e os NEH, observa-se que o $\mathrm{C}-806$ seguiu um modelo cúbico com reduzido coeficiente de determinação e os demais seguiram um modelo linear, porém somente os materiais AG - 9012 e AG - 9014 apresentaram satisfatório coeficiente de determinação, sugerindo que o AG - 9012, de maior sensibilidade de resposta no IAF em condições de estresse hídrico e o material C 806 , de menor sensibilidade.

O efeito do estresse hídrico em plantas de milho com redução no IAF tem sido mostrado por (Denmead e Shaw, 1960), e a existência de correlação entre área foliar máxima por planta e rendimento de grãos em milho para as condições tropicais foram corroborados por (Sobrado, 1990 a 1990 b 1990c). 
Observando a Tabela 11, demonstra-se que os pontos de máxima do IAF não apresentaram proporcionalidade frente aos decréscimos de lâminas de irrigação condicionada aos níveis de estresse hídrico estabelecidos. Percebem-se os máximos de IAF predominando nos $\mathrm{NEH}_{1} ; \mathrm{NEH}_{2}$ e $\mathrm{NEH}_{4}$. Isto mostra as diferenças entre e materiais e que cada um apresentou uma resposta ótima de IAF para uma dada condição de NEH, que normalmente coincidiu com ausência de estresse hídrico, $\mathrm{NEH}_{(1)}$. As regressões polinomiais são oriundas da média das parcelas $\left(\mathrm{NEH}_{1-8}\right)$ dados de quinze observações.

Tabela 11- Regressão polinomial da variável IAF em função do desenvolvimento vegetal expresso em ${ }^{\circ} \mathrm{C}$.dia, com o ponto de máxima do IAF. Condição $(d y / d x)=0 \therefore\left[\left(d^{2} y / d x^{2}\right)=(-)\right]$

\begin{tabular}{ccccccccc}
\hline & \multicolumn{10}{c}{$\mathrm{NEH}_{(1-8)}$} & \multicolumn{2}{c}{$\mathrm{C}-806$} & \multicolumn{1}{c}{$\mathrm{AG}-9012$} & $\mathrm{AG}-9014$ & \multicolumn{2}{c}{$\mathrm{Z}-8392$} \\
\cline { 2 - 9 } & $\mathrm{IAF}_{\text {miximo }}$ & $\mathrm{R}^{2}$ & $\mathrm{IAF}_{\text {miximo }}$ & $\mathrm{R}^{2}$ & $\mathrm{IAF}_{\text {miximo }}$ & $\mathrm{R}^{2}$ & $\mathrm{IAF}_{\text {miximo }}$ & $\mathrm{R}^{2}$ \\
\hline 1 & $2, \mathbf{4 8}$ & 0,8957 & 1,96 & 0,8145 & 2,11 & 0,7909 & 2,44 & $\mathbf{0 , 7 9 8 3}$ \\
2 & 1,78 & 0,9368 & 2,19 & 0,8425 & 2,43 & 0,8820 & 2,26 & $\mathbf{0 , 7 4 3 1}$ \\
3 & 1,52 & 0,9424 & 1,82 & 0,9045 & 1,86 & 0,9077 & 2,27 & 0,8140 \\
4 & 2,13 & 0,8607 & 2,04 & 0,9072 & 1,75 & 0,9252 & 1,18 & 0,8625 \\
5 & 2,22 & 0,8897 & 3,51 & 0,9053 & 2,42 & 0,7330 & 2,07 & 0,8599 \\
6 & 1,07 & 0,9671 & 1,51 & 0,8748 & 2,04 & 0,8351 & 2,33 & 0,8485 \\
7 & 1,07 & 0,9671 & 1,58 & 0,8833 & 1,58 & 0,8845 & 2,07 & 0,8685 \\
8 & 1,95 & 0,9116 & 0,88 & 0,9116 & 1,51 & 0,8500 & 1,84 & 0,9303 \\
\hline
\end{tabular}

Em termos de valores absolutos, na condição $\mathrm{NEH}_{1}$, o material $\mathrm{C}-806$ apresentou maior IAF, traduzindo uma exploração mais eficiente da radiação fotossinteticamente ativa, possibilitando inferir que tal material possui centros de produção de fotoassimilados relativamente maior quando comparado aos demais para uma condição de reposição total de água. $\mathrm{Na}$ condição extrema, máximo de $\mathrm{NEH}_{(8)} \mathrm{o}$ mesmo material, apesar de maior sensibilidade ao estresse nas variações do IAF, suplantou os demais, indicando sua capacidade de enfrentar melhor as adversidades de estresse hídrico em relação à produção, expansão e manutenção de sua área foliar.

Outro aspecto a considerar é a expressão do decréscimo nos máximos de IAF, que se acentua após o $\mathrm{NEH}_{5}$ e $\mathrm{NEH}_{6}$. Condição esta que impõe estresse hídrico mais 
severo tornando os materiais com maior sensibilidade diferenciando-os mais entre si na expressão do IAF.

Outras causas ambientais, com efeito direto no IAF, têm sido estudado por Noldim \& Mundstock, (1988), que avaliaram as modificações ocorridas em plantas de milho submetidas a diferentes condições de temperatura e radiação solar para duas épocas de semeadura. Os autores constataram que a área foliar por planta foi pouco ou quase nada afetada. Já outros trabalhos têm mostrado efeito acentuado de doses de nitrogênio no aumento do IAF com satisfatória reposição de água (Pereira et al. 1981 e Brito, 1995). O fato é que a redução do potencial da água no solo possibilita uma significativa diminuição na translocação dos nutrientes, sentido solução do solo-planta, causado pelo mecanismo reduzido de fluxo de massa em questão, o nitrogênio. Portanto, nota-se uma dependência entre os efeitos do nitrogênio e do potencial de água no solo. Redução no IAF com aumento nos NEH na produção de milho foram encontrados por Espinoza, (1982), neste, o autor observa ainda que tais variações no IAF não estão correlacionadas com a produção de grãos. Oliveira (1993), observou redução do IAF frente à redução da água no solo com proporcional redução na produção de grãos face à redução da capacidade de fotossíntese das plantas.

\subsection{Altura de plantas (AP)}

Pela análise de variância, a altura das plantas (AP) não se observaram diferenças significativas ao nivel de $5 \%$ de probabilidade, entre materiais. Porém, constatou-se redução na AP dentro dos materiais causada pelos níveis de estresse hídrico. Constatação essa em conformidade com Westgate \& Boyer (1986) e Ferreira (1997). A altura média observada nos materiais C - 806; AG - 9012; AG - 9014 e Z 8392 em todos os níveis de estresse hídrico foram: 1,79;1,75; 1,77 e 1,74m respectivamente, (Tabela 12 ).

Variações na altura de plantas de milho, dentre outros fatores, podem ser afetada pelo ciclo do material cultivado, maior a precocidade menor a altura, época de plantio oportunizando diferenças no comprimento do dia às plantas de milho (Souza, 1989; Jong et. al., 1982), doses crescentes de nitrogênio possibilitando incrementos na 
altura (Brito, 1995), densidade de cultivo, afetando indiretamente a intensidade de radiação no dossel vegetal (Durães, 1993) e não influência da densidade sobre a altura das plantas (Barbosa, 1995). Estes efeitos observados por autores citados são nulos neste trabalho, considerando que tais variáveis foram idênticas para todas as parcelas. Assumindo igualdade nas variações de altura entre os materiais de milho e relacionando altura para cada $\mathrm{NEH}_{(1-8)}$, obtém-se uma taxa de $-0,05 \mathrm{~m} \cdot \mathrm{NEH}^{-1}$ de decréscimo na altura, quando se intensifica o estresse hídrico. Resultados similares foram corroborados por Nissen et. al., (1988) e Silva (1990).

Tabela 12 - Altura (m), observada nos quatro materiais de milho nos diferentes $\mathrm{NEH}_{(1-8)}$.

\begin{tabular}{|c|c|c|c|c|c|}
\hline \multirow[b]{2}{*}{$\mathrm{NEH}_{(1-8)}$} & \multicolumn{4}{|c|}{ Materiais de Milho } & \multirow[b]{2}{*}{ Médias } \\
\hline & $\mathrm{C}-806$ & AG - 9012 & AG - 9014 & $Z-8392$ & \\
\hline 1 & 1,95 & $1,73_{b}$ & ${ }_{A} 1,88_{a}$ & $\mathrm{ABl}, 91_{\mathrm{g}}$ & 1,87 \\
\hline 2 & $A B 1,86_{b}$ & ${ }_{A B} 1,88_{b}$ & ${ }_{A} 1,84_{b}$ & 2,05, & 1,91 \\
\hline 3 & ${ }_{A B} 1,84_{a}$ & ${ }_{A} 1,93 \mathrm{a}$ & ${ }_{A B} 1,81_{a}$ & ${ }_{\mathrm{B}} 1,89_{\mathrm{a}}$ & ${ }_{A} 1,87$ \\
\hline 4 & ${ }_{A B} 1,88_{a}$ & $\mathrm{AB} 1,83_{\mathrm{a}}$ & ${ }_{A B} 1,80_{a}$ & $c 1,63_{\mathrm{b}}$ & ${ }_{A B} 1,79$ \\
\hline 5 & ${ }_{A B} 1,80_{a}$ & ${ }_{A B} 1,80_{a}$ & $\mathrm{~A} 1,899_{\mathrm{a}}$ & $c 1,66_{b}$ & ${ }_{A B} 1,79$ \\
\hline 6 & $\mathrm{~B} 1,73_{\mathrm{a}}$ & $\mathrm{Bc} 1,58_{\mathrm{b}}$ & ${ }_{\mathrm{B}} 1,68_{\mathrm{ab}}$ & $\mathrm{c} 1,73_{\mathrm{a}}$ & ${ }_{\mathrm{B}} 1,68$ \\
\hline 7 & ${ }_{\mathrm{B}} 1,68_{\mathrm{ab}}$ & ${ }_{\mathrm{B}} 1,66_{\mathrm{ab}}$ & $\mathrm{AB} 1,75_{\mathrm{a}}$ & $\mathrm{CD} 1,60_{\mathrm{b}}$ & ${ }_{B} 1,67$ \\
\hline 8 & вс 1,58, & $\mathrm{cl}, 57 \mathrm{a}$ & ${ }_{\mathrm{B}} 1,50_{\mathrm{a}}$ & $\mathrm{D} 1,46_{\mathrm{a}}$ & $\mathrm{B} 1,53$ \\
\hline Médias & $1,79_{\mathrm{a}}$ & $1,75_{a}$ & $1,77_{\mathrm{a}}$ & $1,74_{a}$ & 1,76 \\
\hline
\end{tabular}

Em cada série de médias na horizontal, os valores seguidos por letras minúsculas distintas diferem entre si ao nivel de $5 \%$ de probabilidade pelo teste de Tukey, com D.M.S. igual a $0,07 \mathrm{~m}$. Em cada série de médias na vertical, os valores seguidos por letras maiúsculas distintas diferem entre si ao nível de $5 \%$ de probabilidade pelo teste de Tukey, com D.M.S. igual a $0,15 \mathrm{~m}$.

O efeito da irrigação na expressão da AP mostrou-se bem uniforme com o aumento dos NEH. Por outro lado demonstra eficiência na resposta da técnica de aspersão em linha na expressão desta característica agronômica. Valores contrastantes de altura em plantas de milho foram observados por Lopes e Maestri (1981).

Alturas elevadas associadas ou não à posição relativa da espiga na planta (altura da espiga.altura da planta $^{-1}$ ), aumentam a susceptibilidade das plantas ao acamamento, além de dificultar a penetração da radiação solar no dossel vegetal (Allen et al., 1964 e Pereira, 1990). Fenômeno esse que se acentua quanto maior a posição relativa da espiga nas plantas de milho. Pesquisas têm evidenciado a não correlação 
entre altura e rendimento dos grãos. Não obstante, alguns autores têm observado menores alturas em materiais superprecoces, ocorrendo correlação positiva entre altura e número de dias para o florescimento (Souza, 1989). Alterações na altura das plantas de milho associadas a épocas de semeadura foram encontradas, entre outros, por: (Allison \& Daynard, 1979); (Leite, 1985); (Noldin, 1985) e (Oliveira, 1990). Esses autores atribuem que as diferenças ocorridas na AP são decorrentes da diferença no comprimento do dia a que as plantas foram submetidas nas diversas épocas de semeadura, sendo os superprecoces os de menores alturas.

\subsection{Intervalo entre florescimento masculino e feminino (IFMF)}

A análise entre e dentro dos materiais é mostrada na Tabela 13. Observam-se diferenças significativas entre os materiais, sendo o AG - 9012 e AG - 9014 semelhantes entre si e os materiais C - 806 e Z - 8392 também semelhantes entre si, porém diferem estatisticamente dos dois primeiros, apresentado IFMF reduzido. Em relação aos $\mathrm{NEH}$, observam-se diferenças estatísticas entre $\mathrm{NEH}_{(8, \text { e 9) }}$ e $\mathrm{NEH}_{(1)}$. Os resultados mostram gradiente crescente e contínuo ao longo dos $\mathrm{NEH}$, não reproduzindo o mesmo gradiente quando se analisa cada material isoladamente.

Tabela 13 - Intervalo entre florescimento masculino e florescimento feminino (IFMF), expresso em ${ }^{\circ} \mathrm{C}$.dia, em quatro materiais de milho submetidos a diferentes niveis de estresse hídrico (NEH).

\begin{tabular}{|c|c|c|c|c|c|}
\hline \multirow[b]{2}{*}{$\mathrm{NEH}_{(1-8)}$} & \multicolumn{4}{|c|}{ Materiais de Milho } & \multirow[b]{2}{*}{ Médias } \\
\hline & $C-806$ & $\mathrm{AG}-9012$ & AG - 9014 & $Z-8392$ & \\
\hline 1 & $36,65_{b}$ & $\mathrm{AB}_{55,70_{\mathrm{a}}}$ & $C_{30,34_{b}}$ & $\overline{c_{4,25}}$ & $\mathrm{~B}_{31,74}$ \\
\hline 2 & ${ }^{\mathrm{B}} 49,09_{\mathrm{ab}}$ & $\mathrm{AB}_{55,48,}$ & $\mathrm{BC}_{39,81_{\mathrm{b}}}$ & $\mathrm{BC}_{24,21_{\mathrm{c}}}$ & ${ }^{A B} 42,15$ \\
\hline 3 & ${ }^{A B} 60,63_{x}$ & ${ }^{8} 40,80_{b}$ & ${ }^{\mathrm{B}} 67,41_{\mathrm{a}}$ & ${ }^{B} 38,82_{b}$ & $\mathrm{AB}_{51,92}$ \\
\hline 4 & ${ }^{\mathrm{B}} 40,25_{\mathrm{b}}$ & ${ }^{\mathrm{B}} 42,13_{\mathrm{b}}$ & $\mathrm{BC}_{41,17_{b}}$ & ${ }^{\mathrm{A}} 71,84_{\mathrm{a}}$ & $\mathrm{AB}_{48,85}$ \\
\hline 5 & ${ }^{\mathrm{B}} 30,83_{\mathrm{b}}$ & $\mathrm{AB}_{55,35,}$ & $\mathrm{BC}_{53,53,}$ & $\mathrm{AB}_{54,49}$ & ${ }^{\mathrm{AB}} 48,55$ \\
\hline 6 & ${ }^{\mathrm{B}} 41,74_{\mathrm{c}}$ & ${ }^{\mathrm{A}} 84,06$, & ${ }^{\mathrm{B}} 65,83_{\mathrm{b}}$ & ${ }^{B} 36,70_{c}$ & $\mathrm{AB}_{57,08}$ \\
\hline 7 & A8 81,59, & ${ }^{\mathrm{AB}_{56}}, 67 \mathrm{~b}$ & ${ }^{B C} 52,29_{b}$ & ${ }^{\mathbf{A B}} 61,66_{\mathrm{b}}$ & ${ }^{\mathrm{A}} 63,05$ \\
\hline 8 & $\mathrm{AB}_{53,76_{\mathrm{c}}}$ & ${ }^{\mathrm{A}} 79,79_{\mathrm{b}}$ & ${ }^{\mathrm{A}} 101,43_{\mathrm{a}}$ & $\mathbf{A B}_{55,70_{\mathbf{c}}}$ & ${ }^{A} 72,67$ \\
\hline Médias & $49,32_{b}$ & $58,75_{\mathrm{a}}$ & $56,48_{a}$ & $43,46_{b}$ & 52,00 \\
\hline
\end{tabular}

Em cada série de médias na horizontal, os valores seguidos por letras minúsculas distintas diferem entre si ao nivel de $5 \%$ de probabilidade pelo teste de Tukey, com D.M.S. igual a $6.40^{\circ} \mathrm{C}$.dia. Em cada série de médias na vertical, os valores seguidos por letras maiúsculas distintas diferem entre si ao nivel de $5 \%$ de probabilidade pelo teste de Tukey, com D.M.S. igual a $31,1{ }^{\circ} \mathrm{C}$.dia. 
IFMF nos materiais AG - 9012 e Ag - 9014 foi relativamente prolongado, o que numa condição de exposição das plantas ao estresse hídrico possibilita consequências indesejáveis no dossel tais como: desidratação dos estilos estigmas, aumento da protândria, aborto dos sacos embrionários, redução do indice de germinação dos grãos de pólen e, como consequência, redução significativa no rendimento de grãos. Genericamente, a variação temporal entre as inflorescências masculina e feminina nas plantas de milho vão de 2 a 4 dias (Fancelli \& Dourado Neto, 1997).

Variações no IFMF, como efeito direto dos NEH, podem ser entendidas como uma estratégia do material para enfrentar as adversidades impostas pela escassez de água no ambiente, porém não se estabeleceu uma relação funcional entre as variações do IFMF e NEH. A dimensão dessas variações para NEH especificos mostra entre os materiais aqueles de mecanismos mais eficientes frente ao estresse hídrico.

A época de ocorrência do florescimento masculino foi praticamente idêntica dentro e entre materiais; entretanto, durante a época do florescimento feminino ocorreram variações entre as parcelas experimentais, redundando em intervalos de IFMF com pequenas diferenças. A amplitude da expressão deste intervalo (duração do evento), é uma característica individual dos germosplasmas (Bassetti \& Westgate, 1993), podendo esta característica ser estável ou não, dependendo exclusivamente do material em si. O IFMF, reduzido e estável no germoplasma de um material, é assumido como uma característica de importante valor adaptativo às condições de seca em programas de melhoramento de milho. Bolaños \& Edmeades (1995), em trabalhos de seleção genética para esta característica, mostraram redução no IFMF, sugerindo ser o mesmo de elevada herdabilidade, mostrando, inclusive, boa correlação entre as variações na produção de grãos e variações no IFMF. Portanto, materiais com IFMF reduzido ou com a capacidade de reduzir tal intervalo frente às diversas condições de estresse hídrico são desejáveis para cultivo extemporâneo.

O comportamento do material AG - 9014 para cada condição de $\mathrm{NEH}_{(1-8)}$, mostrou-se contínuo e crescente. Comportamento semelhante foi observado no material C - 806. Estes, sob uma análise isolada, apresentam tendência de aumento no IFMF na 
mesma proporção de aumento do estresse hídrico, o que é um comportamento morfofisiológico extremamente indesejável.

Alguns trabalhos, (Edmeades et al., 1989; Durães et al., 1997), tem mostrado que IFMF é expressão do germoplasma do material somado aos efeitos do ambiente havendo, porém, uma superioridade do primeiro fator em detrimento do segundo. Assim as pesquisas têm sido conduzidas para a fixação deste característica, através de seleção, em materiais de milho. A Figura 5 apresenta os resultados do IFMF para cada nível de estresse hídrico nos quatros materiais de milho.
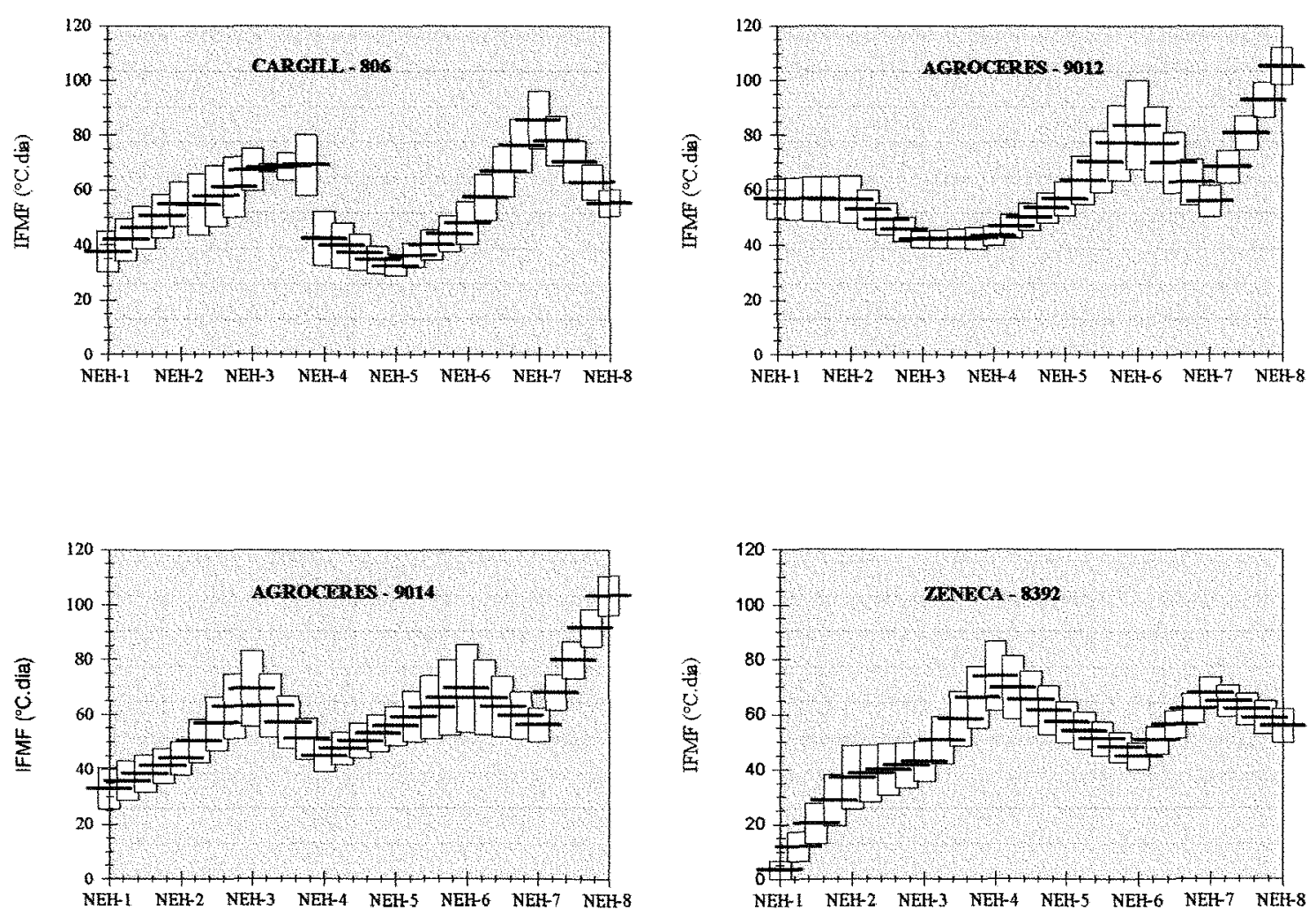

Figura 5 - Intervalo entre florescimento masculino e feminino-IFMF, expresso ${ }^{\circ} \mathrm{C}$.dia, comparado aos diferentes níveis de estresse hídrico, observado nos materiais C - 806, AG - 9012, AG - 9014 e Z - 8392. 
A Figura 5 mostra ainda os valores extremos e valor médio por $\mathrm{NEH}_{(1-8)} \mathrm{em}$ cada material (variação dentro dos $\mathrm{NEH}_{(1-8)}$, e dentro dos materiais de milho), observa-se que nos materiais AG-9012 e AG-9014 ocorreram tendências semelhantes, para uma mesma faixa de variação, aumento do IFMF para NEH extremo. Pelos resultados nota-se que a variável IFMF relacionada aos $\mathrm{NEH}_{(1-8)}$, mostra uma relação causa-efeito com IFMF muito dispersa com tendência indefinida.

As variações observadas mostram uma amplitude total bastante semelhante entre si $\left(53,30\right.$ a $87,79^{\circ} \mathrm{C}$.dia nos materiais C-806 e AG-9014, respectivamente), mas a análise dentro dos NEH não se identificou a existência de um fator de proporcionalidade entre IFMF versus $\mathrm{NEH}_{(1-8)}$. No extremo $\mathrm{NEH}_{7}$ e $\mathrm{NEH}_{8}$, os materiais $\mathrm{C}-806$ e Z-8392, apresentam comportamento de IFMF em declínio, performance inversa aos materiais AG-9014 e AG-9012 nas mesmas condições, evidenciando que variações de IFMF, com tendências de respostas, somente ocorrem em condições mais extremas de estresse hídrico. Alterações no IFMF principalmente a sua redução em função do estado (potencial) da água na planta foram observados por Herrero \& Johnson (1981); Westgate \& Boyer, (1986) e, em função de altos níveis de densidades de cultivo, por Buren et al., (1974); Edmeades \& Daynard, (1979) e Dow et al. (1984). Sendo que tais alterações, impostas por condicionantes do meio, não apresentaram coeficientes de proporcionalidade com as alterações no IFMF.

Evidentemente há necessidade de mais estudos com repetibilidade no tempo para estes materiais, observando a consistência da resposta IFMF versus NEH, externando de forma mais clara e acentuada a resposta morfo-fisiológica destes materiais a diferentes condições de estresse hídrico. IFMF reduzido é desejável para as condições de safrinha e agregar a essa condição um material capaz de reduzir IFMF frente à intensidade do estresse hídrico, torna-o mais seguro diante dos riscos da ocorrências de veranicos nesta modalidade de cultivo. 


\section{6. Índice de colheita (IC)}

$\mathrm{O}$ índice de colheita (IC) observado nos materiais de milho $\mathrm{C}-806$; $\mathrm{AG}$ 9012; AG - 9014 e Z - 8392, nos diferentes $\mathrm{NEH}_{1-8}$, comparado estatisticamente, são mostrados na Tabela 14.

Tabela 14 - Índice de colheita (IC) observado nos quatros materiais de milho submetidos a diferentes níveis de estresse hídrico $\left(\mathrm{NEH}_{1-8}\right)$.

\begin{tabular}{|c|c|c|c|c|c|}
\hline \multirow[b]{2}{*}{$\mathrm{NEH}_{(1-8)}$} & \multicolumn{4}{|c|}{ Materiais de Milho } & \multirow[b]{2}{*}{ Médias } \\
\hline & $C-806$ & AG - 9012 & AG - 9014 & $Z-8392$ & \\
\hline 1 & ${ }^{\mathrm{A}} 0,46_{\mathrm{a}}$ & ${ }^{\mathrm{B}} 0,20_{\mathrm{c}}$ & ${ }^{A B} 0,45_{a}$ & ${ }^{A} 0,36_{b}$ & ${ }^{A} 0,37$ \\
\hline 2 & ${ }^{A} 0,42$ & ${ }^{\mathrm{B}} 0,20_{\mathrm{c}}$ & $\mathrm{AB}_{0}, 3 \mathrm{O}_{\mathrm{b}}$ & ${ }^{A} 0,3 l_{b}$ & ${ }^{A} 0,31$ \\
\hline 3 & ${ }^{\mathrm{A}} 0,37_{\mathrm{ab}}$ & ${ }^{A} 0,42$ & $\mathrm{AB}_{0,32_{\mathrm{b}}}$ & ${ }^{A} 0,31_{b}$ & ${ }^{A} 0,36$ \\
\hline 4 & ${ }^{\mathrm{A}} 0,47_{\mathrm{a}}$ & $\mathbf{A B}_{0,38}$ & ${ }^{\mathrm{A}} 0,47_{\mathrm{a}}$ & ${ }^{\mathrm{A}} 0,43_{\mathrm{ab}}$ & ${ }^{\mathrm{A}} 0,44$ \\
\hline 5 & ${ }^{\mathrm{A}} 0,45_{\mathrm{a}}$ & ${ }^{\mathrm{A}} 0,42_{\mathrm{a}}$ & ${ }^{\mathrm{AB}} 0,41_{\mathrm{a}}$ & ${ }^{\mathrm{A}} 0,39_{\mathrm{a}}$ & ${ }^{A} 0,42$ \\
\hline 6 & ${ }^{\mathrm{A}} 0,45_{\mathrm{a}}$ & ${ }^{A} 0,4 I_{a}$ & ${ }^{A B} 0,40$ & ${ }^{\mathrm{A}} 0,45_{\mathrm{a}}$ & ${ }^{A} 0,43$ \\
\hline 7 & ${ }^{A} 0,45_{a b}$ & $\mathbf{A B}_{0,39_{\mathbf{b}}}$ & ${ }^{\mathrm{B}} 0,26_{\mathrm{c}}$ & ${ }^{\mathrm{A}} 0,47 \mathrm{a}$ & ${ }^{\mathbf{A}} 0,39$ \\
\hline 8 & ${ }^{A} 0,45_{a}$ & ${ }^{A B} 0,36_{b}$ & ${ }^{\mathrm{AB}} 0,35_{\mathrm{b}}$ & ${ }^{A} 0,42_{a b}$ & ${ }^{A} 0,40$ \\
\hline Médias & $0,44_{a}$ & $0,35_{c}$ & $0,37_{b c}$ & $0,39_{\mathrm{b}}$ & 0,39 \\
\hline
\end{tabular}

Em cada série de médias na horizontal, os valores seguidos por letras minúsculas distintas diferem entre si ao nivel de $5 \%$ de probabilidade pelo teste de Tukey, com D.M.S. (5\%) igual a 0,03 . Em cada série de médias na vertical, os valores seguidos por letras maiúsculas distintas diferem entre si ao nível de $5 \%$ de probabilidade pelo teste de Tukey, com D.M.S. (5\%) igual a 0,10 .

Os indices de colheita foram idênticos nos $\mathrm{NEH}_{(1-8)}$ estabelecidos, apresentando valor médio igual a 0,39 . Porém entre materiais de milho percebem-se três niveis distintos de IC para os quatros materiais. O material C - 806 foi estatisticamente o de maior valor, contrastando com de menor IC, material AG - 9012. Isto permite supor que o material $\mathrm{C}-806$ apresentou maior capacidade de particionar fotoassimilados para grãos, quando comparados aos demais. Os resultados mostram também que o IC nos materiais $\mathrm{C}-806$ e $\mathrm{Z}-8392$ foram idênticos nos diferentes $\mathrm{NEH}_{(1-8)}$, não demostrando sensibilidade às condições de estresse hídrico estabelecido.

Resultados com uma relação funcional mais consistentes, relacionando IC e estresse hídrico na produção de grãos de milho foram encontrados entre outros por Doss (1974), mostrando variação de até $48 \%$ em função do fator água, e na produção de grãos de trigo por Poostchi et al., (1972). Comparando outros fatores do meio e sua influência no IC de materiais de milho, cita-se Machado et al. (1982) estes, trabalhando com quatro 
materiais de milho em três níveis de densidades de cultivo $(66.666 ; 50.000$ e 33.333 plantas. ha ${ }^{-1}$ ) não encontraram variações no IC, que se manteve ao redor de 0,4 .

Uma importante e sistematizada abordagem sobre densidades de plantio e alterações morfológicas nas plantas podem ser vistos em Pereira, (1989). O autor revela que quanto menor a competição intra-especifica entre plantas cultivadas maiores serão seus índices de colheita, portanto trata-se de uma relação inversa. Historicamente o aumento do rendimento de grãos foi via aumento do IC, tendo o rendimento biológico se mantido constante.

$\mathrm{Na}$ fase reprodutiva, os grãos são drenos metabólicos preferenciais (Costa, 1994), diferenciando-se os materiais que fisiologicamente, no período de enchimento dos grãos (stay green), encontrarem-se em condições de ofertar quantidades maiores de fotoassimilados nos centros de produção e com larga capacidade de dreno para grãos. Materiais capazes de ofertarem mais fotoassimilados e com pouca sensibilidade em relação ao IC na condição de supressão ou estresse hídrico devem ser priorizados para em cultivos de safrinha (semeadura tardia).

\subsection{Produção de grãos (PG)}

A produção de grãos entre materiais mostrou-se significativamente diferente, Anexo G. Analisando as produções de grãos padronizadas a uma umidade de 13,5\%, em cada material dentro dos $\mathrm{NEH}_{(1-8)}$, obteve-se por regressão linear significativa, e com satisfatórios coeficientes de determinação $\left(R^{2}\right): 0,9624 ; 0,8325 ; 0,7546$ e 0,7766 respectivamente para os materiais C - 806; AG - 9012; AG - 9014 e Z - 8392. Verificase pela Figura 6 que a distribuição da produtividade como variável dependente em relação aos $\mathrm{NEH}_{(1-8)}$, seguiu um modelo linear.

O material Z - 8392 apresentou maior variação na produtividade para cada $\mathrm{mm}$ de água aplicada, sugerindo maior sensibilidade produtiva deste material às condições de seca. Contrastando, o material AG - 9014 foi o de menor sensibilidade. Entretanto, a função mais consistente entre produtividade e lâminas de água aplicada foi observada no material C -806 . 
A redução no rendimento de grãos imposta pelos $\mathrm{NEH}_{(1-8)}$ pode estar associada a um expressivo aumento na taxa de respiração das plantas com conseqüente redução na taxa de redistribuição de fotoassimilados para os centros de consumo na planta, conforme observações de Brevedan \& Hodges, (1973).

Nas plantas tipo $\mathrm{C}_{4}$ a maior parte dos fotoassimilados produzidos são exportados para os drenos (consumo). Os centros de consumo de fotoassimilados em plantas de milho são preferenciais em relação aos órgãos da planta como função de seu desenvolvimento que, na fase de enchimento de grãos, estes, são drenos preferenciais, resultando numa maior produção. As maiores produções são conseqüências de uma melhor partição mas, principalmente de uma maior capacidade de produção de fotoassimilados.
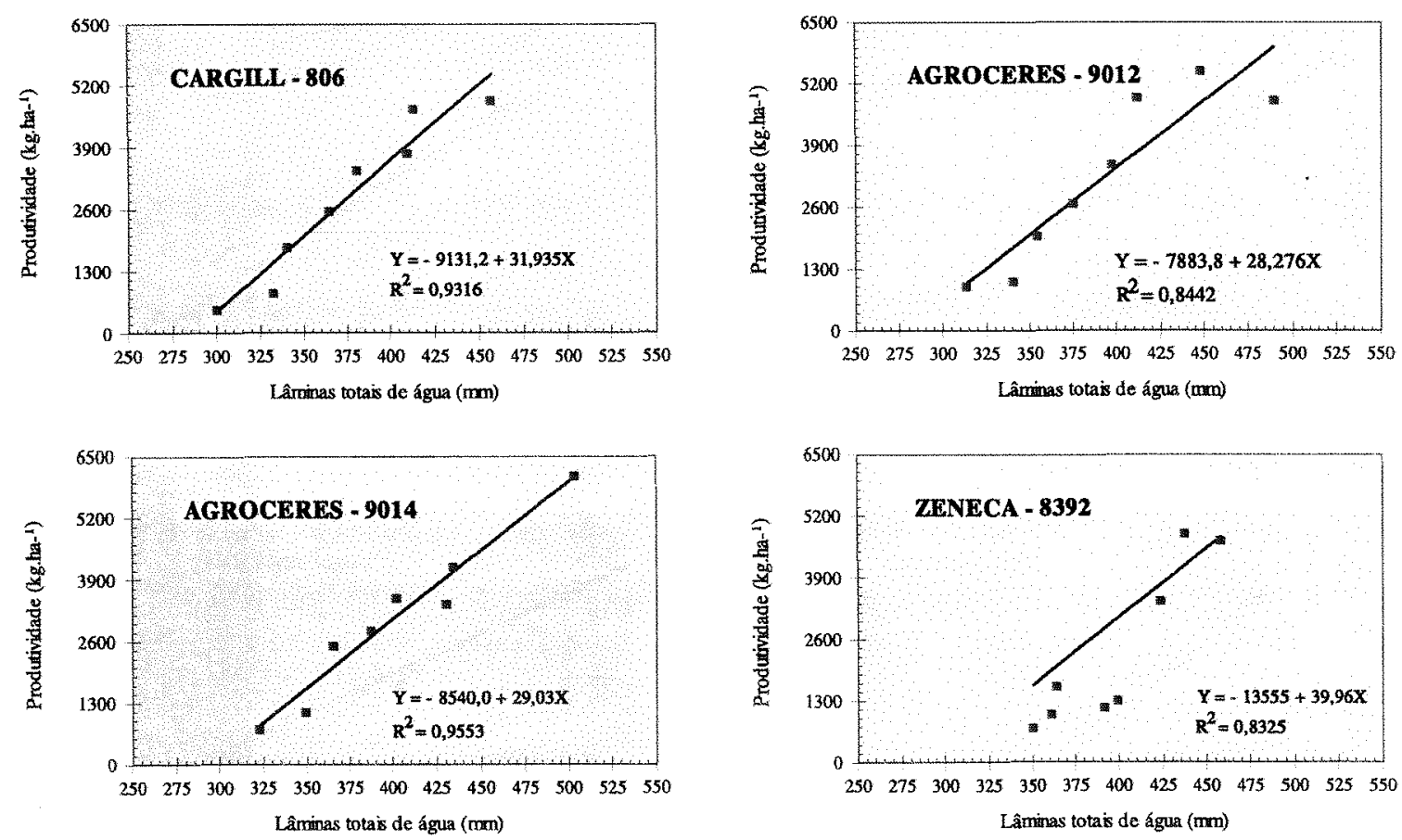

Figura 6 - Produtividade $\left(\mathrm{kg} \cdot \mathrm{ha}^{-1}\right)$ relacionada aos niveis de estresse hídrico $\mathrm{NEH}_{(1-8)}$, observado nos materiais Cargill - 806, Agroceres - 9012, Agroceres $9014 \mathrm{e}$ Zeneca-8392. 
Em geral a intensidade de consumo de fotoassimilados por parte de um dreno é condicionada pelo número, dimensões, proximidade, sincronia e taxa de crescimento dos órgãos de acumulação de fotoassimilados (Evans, 1975). No subperído de F-MF em plantas de milho, os grãos (enchimento) assumem preferência pelos fotoassimilados, onde os $\mathrm{NEH}_{(1-8)}$ impostos de maneira acumulativa, tiveram efeito preponderante nos rendimentos aqui observados.

\subsection{Fator de resposta da cultura (ky) ao estresse hídrico}

Os valores de ky observados para os quatro materiais compreendendo todo o ciclo das plantas foram superiores a uma unidade $(>1,0)$, Figura 7 .

Neste trabalho, a relação funcional entre déficit de evapotranspiração relativa [1-(ETr(ij). $\left.\left.\operatorname{ETm}_{(\mathrm{ij})}{ }^{-1}\right)\right]$ e déficit de rendimento relativo [1-( $\left.\left.\operatorname{Yr}_{(\mathrm{ij})} \cdot \mathrm{Ym}_{(\mathrm{ij})}{ }^{-1}\right)\right]$ possibilitou a estimativa de $\mathrm{k} y$ na condição de até $50 \%$ da água prontamente disponível às plantas. $\mathrm{O}$ coeficiente de resposta ky tem como causa de sua expressão a espécie vegetal, fases específicas de crescimento vegetal, práticas agronômicas e manejo da irrigação.

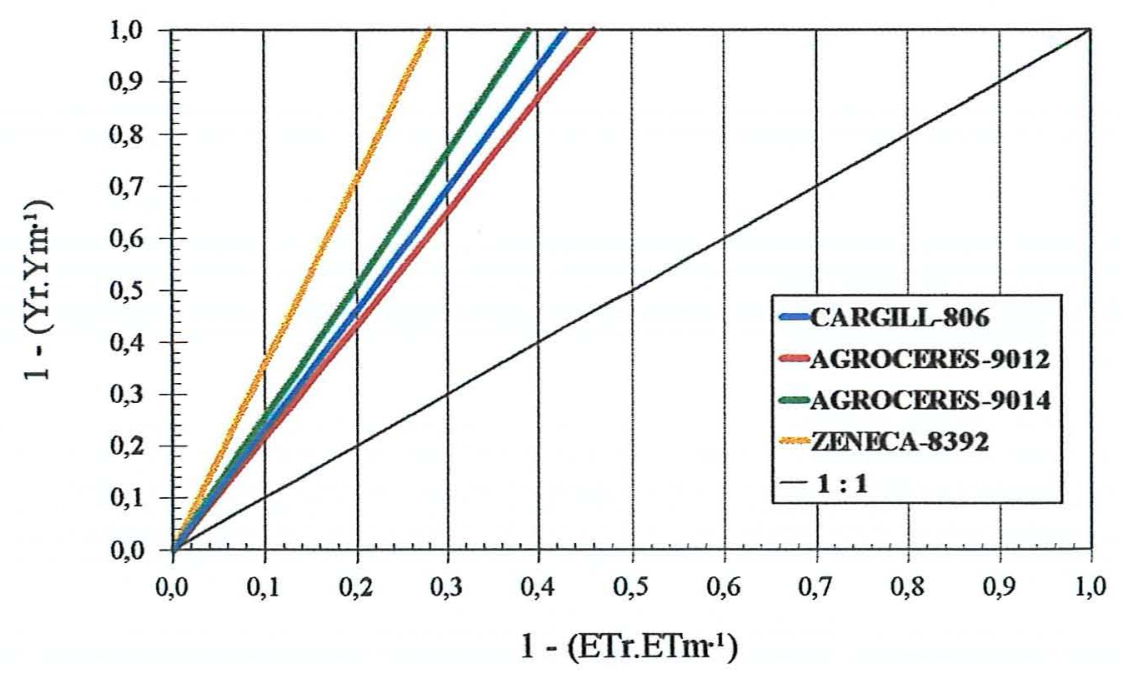

Figura 7 - Relação entre déficit de evapotranspiração relativa [1-(ETr.ETm $\left.\left.{ }^{-1}\right)\right]$ e déficit no rendimento relativo $\left[1-\left(\mathrm{Yr}_{\mathrm{r}} \mathrm{Ym}^{-1}\right)\right]$ observado nos quatro materiais de milho. 
A metodologia, aqui utilizada para a aplicação de água, supõe-se distribuição uniforme com déficits acumulativos em todos os subperíodos de desenvolvimento dos materiais de milho. Isto possibilita o uso de ky médio compreendendo todo o ciclo das plantas representando cada material.

Tradicionalmente tem-se utilizado, em pesquisas com a cultura do milho, coeficientes de resposta que oscilam em torno 2,3 , referente ao subperíodo florescimento a enchimento dos grãos e valores em torno de 1,25 , compreendendo o período total de crescimento (Doorenbos \& Kassam, 1979). Recentemente, estes foram adotados para estimativa de rendimento relativo em milho por Alfonsi, (1996). Os valores observados de ky, para todo o ciclo dos materiais de milho em cada condição de $\mathrm{NEH}_{(1-8)}$, são mostrados nas Tabelas 15 e 16 .

Um aspecto a considerar é a qualidade da estimativa das variáveis [1$\left.\left(\operatorname{ETr}_{(\mathrm{ijj})} \cdot \mathrm{ETm}_{(\mathrm{ij})}{ }^{-1}\right)\right]$ e $\left[1-\left(\mathrm{Yr}_{(\mathrm{ij})} \cdot \mathrm{Ym}_{(\mathrm{ij})}{ }^{-1}\right)\right]$, na determinação do coeficiente ky. Reduzidas variações em ETm e/ou Ym comparado às determinações nas parcelas com cada $\mathrm{NEH}_{(1-}$ 8), acarreta expressivas variações em ky. Portanto, inferências generalizadas ou conclusivas sobre o rendimento de grãos e possiveis associações com estresse hídrico (ky), observado nos quatro materiais, assumem restrições de âmbito metodológico.

Tabela 15 - Coeficientes de resposta $(K y)$ ao estresse hídrico para os diferentes materiais de milho com base na hipótese de linearidade $\left(\right.$ ETr.ETm $^{-1} \geq 50 \%$ ), mostrando $K y$ médio por material igual a 2,38 e 1,89; C-806 e AG-9012, respectivamente.

\begin{tabular}{ccccccc}
\hline & \multicolumn{2}{c}{ ETr.ETm $^{-1}$} & \multicolumn{2}{c}{ Yr.Ym $^{-1}$} & \multicolumn{2}{c}{ Ky } \\
\cline { 2 - 7 } NEH $_{(1-8)}$ & $\mathrm{C}-806$ & AG - 9012 & C - 806 & AG - 9012 & C-806 & AG - 9012 \\
\hline 1 & 1,00 & 1,00 & 1,00 & 0,89 & 0 & 0 \\
2 & 0,92 & 0,91 & 0,96 & 1,00 & 0,48 & 0 \\
3 & 0,92 & 0,84 & 0,77 & 0,90 & 2,71 & 0,05 \\
4 & 0,86 & 0,81 & 0,70 & 0,64 & 2,11 & 1,90 \\
5 & 0,82 & 0,77 & 0,52 & 0,49 & 2,70 & 2,20 \\
6 & 0,77 & 0,72 & 0,37 & 0,36 & 2,70 & 2,29 \\
7 & 0,75 & 0,69 & 0,17 & 0,19 & 3,37 & 2,60 \\
8 & 0,65 & 0,64 & 0,10 & 0,17 & 2,61 & 2,32 \\
\hline \multicolumn{7}{c}{}
\end{tabular}


Tabela 16 - Coeficientes de resposta $(K y)$ ao estresse hídrico para os diferentes materiais de milho com base na hipótese de linearidade $\left(\mathrm{ETr}_{\mathrm{ETm}}{ }^{-1} \geq 50 \%\right)$, mostrando $K y$ médio por material igual a 2,31 e 4,16; AG-9014 e Z-8392, respectivamente.

\begin{tabular}{|c|c|c|c|c|c|c|}
\hline \multirow[b]{2}{*}{$\mathrm{NEH}_{(1-8)}$} & \multicolumn{2}{|c|}{ ETrETm ${ }^{-1}$} & \multicolumn{2}{|c|}{ Yr.Ym ${ }^{-1}$} & \multicolumn{2}{|c|}{$\mathrm{Ky}$} \\
\hline & $\overline{A G-9014}$ & $Z-8392$ & $\mathrm{AG}-9014$ & Z-8392 & $\mathrm{AG}-9014$ & $Z-8392$ \\
\hline 1 & 1,00 & 1,00 & 1,00 & 0,97 & 0 & $\overline{0}$ \\
\hline 2 & 0,86 & 0,96 & 0,68 & 1,00 & 2,25 & 0 \\
\hline 3 & 0,84 & 0,92 & 0,56 & 0,70 & 2,72 & 3,88 \\
\hline 4 & 0,79 & 0,86 & 0,58 & 0.27 & 2,02 & 5,30 \\
\hline 5 & 0,76 & 0,85 & 0,46 & 0.24 & 2,24 & 5,06 \\
\hline 6 & 0,71 & 0,80 & 0,41 & 0,33 & 2,04 & 3,29 \\
\hline 7 & 0,68 & 0,80 & 0,18 & 0,21 & 2,56 & 3,78 \\
\hline 8 & 0,63 & 0,77 & 0,12 & 0,15 & 2,36 & 3,64 \\
\hline & Ky médio & ciclo em & naterial de 1 & & 2.31 & 4,16 \\
\hline
\end{tabular}

Outro aspecto é que, neste trabalho, a metodologia utilizada na estimativa do consumo de água pelas plantas de milho (ETr) não isola de forma consistente o efeito da variabilidade espacial das características hídricas do solo e as parcelas submetidas a NEH maiores, a estimativa dos fluxos verticais (descendente e ascendente) de água não apresentam a mesma precisão das parcelas com reposição total de água em função do decréscimo exponencial das densidades de fluxos por gradientes de potencial. Estudos na direção de quantificar o efeito destas dificuldades, ou seja, evidenciando claramente $o$ efeito da variabilidade espacial dos atributos do solo no balanço final de água em solo cultivado são corroborados entre outros por; Villagra et al. (1988), Villagra et al. (1995) e Reichardt et al. (1993).

Em cada material, observam-se coeficientes de resposta (ky), com tendências de aumento, conforme se amplia o estresse hídrico, porém com incrementos diferenciados e distintos. Assumindo o valor médio de ky como a expressão da sensibilidade de cada material aos efeitos do estresse hídrico, aqueles com maior perda no rendimento de grãos foram; $Z-8392, C$ - 806, AG - 9014 e AG - 9012, respectivamente. Se por um lado materiais geneticamente de altos rendimentos são mais sensiveis ao estresse hídrico, os valores de ky encontrados apontam dentre os materiais, aqueles de menor sensibilidade ao estresse hidrico, ou seja, materiais que, submetidos a uma condição de estresse hídrico sofrem pouca alteração em sua performance produtiva comparativamente a outros materiais, no caso específico, o material AG - 9012. 
Uma maior capacidade produtiva, em resposta ao estresse hídrico, nem sempre pode ser traduzida como uma maior capacidade produtiva de grãos em termos absolutos. Rendimentos de grãos de milho considerados bons são da ordem de 6000 a $9000 \mathrm{~kg} \cdot \mathrm{ha}^{-1}$, o que proporciona uma eficiência de utilização da água também considerada razoável, na ordem de 0,8 a $1,6 \mathrm{~kg} \cdot \mathrm{m}^{-3}$, (Doorenbos \& Kassan, 1979).

Relacionando a produção obtida por unidade de área (ha) e o volume de água consumido por área (ha) em cada material, obtém-se a relação de eficiência de utilização de água (e.u.a.) para cada material, Tabela 17.

Tabela 17 - Eficiência no uso da água observada nos quatro materiais de milho para cada situação de estresse hídrico $\left(\mathrm{NEH}_{1-8}\right)$

\begin{tabular}{cccccccccc}
\hline Materiais & $\mathrm{NEH}_{1}$ & $\mathrm{NEH}_{2}$ & $\mathrm{NEH}_{3}$ & $\mathrm{NEH}_{4}$ & $\mathrm{NEH}_{5}$ & $\mathrm{NEH}_{6}$ & $\mathrm{NEH}_{7}$ & $\mathrm{NEH}_{8}$ & Média \\
\hline $\mathrm{C}-806$ & 1,11 & 1,15 & 0,94 & 0,90 & 0,74 & 0,56 & 0,27 & 0,18 & 0,73 \\
$\mathrm{AG}-9012$ & 0,99 & 1,22 & 1,21 & 0,89 & 0,73 & 0,57 & 0,31 & 0,30 & 0,78 \\
$\mathrm{AG}-9014$ & 1,25 & 0,98 & 0,82 & 0,88 & 0,74 & 0,93 & 0,34 & 0,25 & 0,77 \\
$\mathrm{Z}-8392$ & 1,02 & 1,14 & 0,82 & 0,33 & 0,30 & 0,45 & 0,25 & 0,21 & 0,57 \\
\hline
\end{tabular}

Os resultados mostram que a taxa média de variação no rendimento $\left(\mathrm{kg} \cdot \mathrm{ha}^{-1}\right)$ em relação ao consumo hídrico unitário $\left(\mathrm{m}^{3} \cdot \mathrm{ha}^{-1}\right)$ é de: 0,$73 ; 0,78 ; 0,77$ e 0,57 nos materiais C-806; AG-9012; AG-9014 e Z-8392, respectivamente. Se consideradas as variações na e.u.a. ao longo dos $\mathrm{NEH}_{(1-8)}$, observam-se expressivos decréscimos nos valores na e.u.a., caracterizando, nas parcelas experimentais onde a suplementação de água foi igual ou próxima à reposição total pela irrigação, que a eficiência na utilização

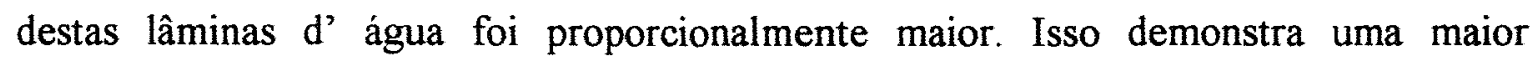
capacidade para produção de grãos destes materiais, em situações com pronunciado estresse hídrico. Entretanto, os valores obtidos da e.u.a. estão em níveis inferiores àqueles sugeridos por Doorenbos \& Kassan, (1979). Estes citam valores entre 0,8 a 1,6 $\mathrm{kg}$ de grãos. $\mathrm{m}^{-3}$ de água como de boa e.u.a.. Trabalhos de pesquisa com cultivo de milho sem restrição de água têm mostrado e.u.a. dentro do referido intervalo (Volpe, 1986) e (Oliveira, 1993). A Figura 8, mostra as variações ocorridas na e.u.a. e as condições de estresse hidrico impostas nas parcelas experimentais $\mathrm{NEH}_{(1-8) \text {. }}$

Sob condições de estresse hídrico, o material Z - 8392 apresentou melhor e.u.a., porém o material $\mathrm{C}$ - 806 obteve melhor coeficiente de uniformidade e também 
satisfatório crescimento da e.u.a. nas condições NEH mais severas, Figura 8. Ao considerar valores médios de e.u.a., os materiais $\mathrm{C}-806$, AG - 9012 e AG - 9014 são semelhantes entre si e, contrastando todos com o material $\mathrm{Z}-8392$, o de menor e.u.a..
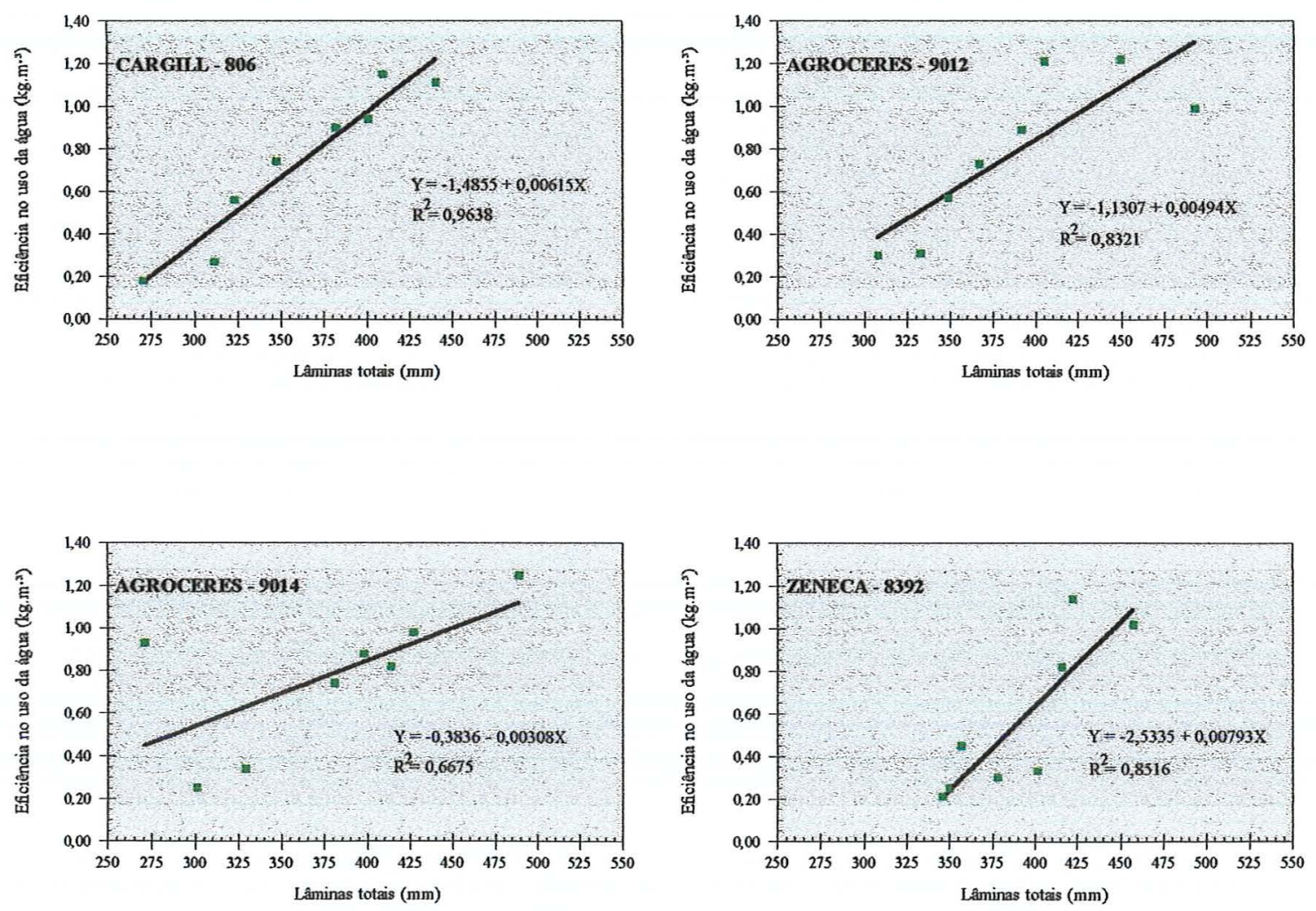

Figura 8 - Eficiência no uso da água observada nos materiais C - 806, AG - 9012, AG 9014 e Z - 8392, comparada aos diferentes níveis de estresse hídrico (lâminas totais de água aplicada). 


\section{CONCLUSÕES}

Com base na metodologia utilizada e nos resultados obtidos neste experimento, pode-se inferir as seguintes assunções conclusivas:

i) Os materiais de milho Zeneca - 8392 e Cargill - 806 apresentaram maiores taxas de crescimento do IAF em relação aos materiais Agroceres - 9014 e Agroceres - 9012;

ii) A altura das plantas nos quatro materiais não se diferiram estatisticamente, mas mostrouse variável ao longo nos níveis de estresse hídrico dentro de cada material;

iii) A característica agronômica, intervalo entre florescimento masculino e florescimento feminino mostrou-se estatisticamente significativa. Os materiais C -806 e $Z-8392$ apresentaram IFMF menores porém, não se estabeleceu uma relação funcional de causa efeito entre IFMF versus $\mathrm{NEH}_{(1-8)}$;

iv) O índice de colheita foi maior no material Cargill - 806 quando comparado aos demais. Entretanto, não se estabeleceu um coeficiente de proporcionalidade entre as variações no IC e níveis de estresse hídrico $(1-8)$;

v) Os materiais Agroceres - 9014 e C - 806 apresentaram maiores rendimentos ao nível de $5 \%$ de probabilidade;

vi) O maior coeficiente de resposta Ky foi observado no material $Z-8392$, mostrando-se mais sensível ao estresse hídrico seguido dos materiais C - 806, AG - 9014 e AG - 9012 e; vii) Em relação à eficiência no uso da água (e.u.a.), os materiais Cargill - 806, Agroceres9012 e Agroceres - 9014 apresentaram mesma e.u.a. diferenciando-se o material Zeneca 8392 , de menor e.u.a.. 
ANEXOS 

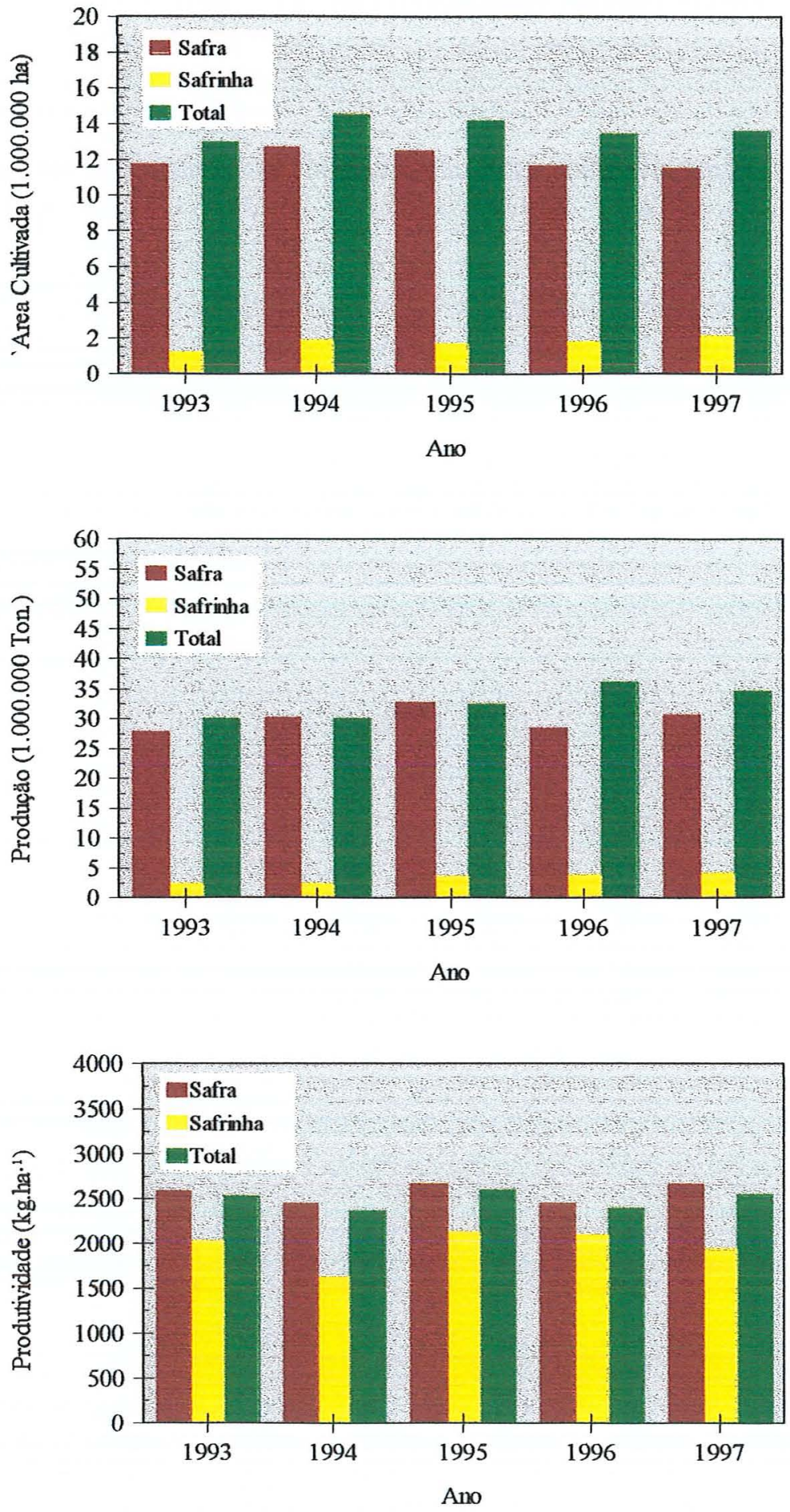

Anexo A - Evolução da área cultivada, produção e produtividade de milho, respectivamente, safra e safrinha, em nível nacional. Período de 1993 a 1997. Fonte: Levantamento sistemático da produção agrícola, novembro, 1997. IBGE. In: A Granja, n.591, p.14-19, mar. 1998. 

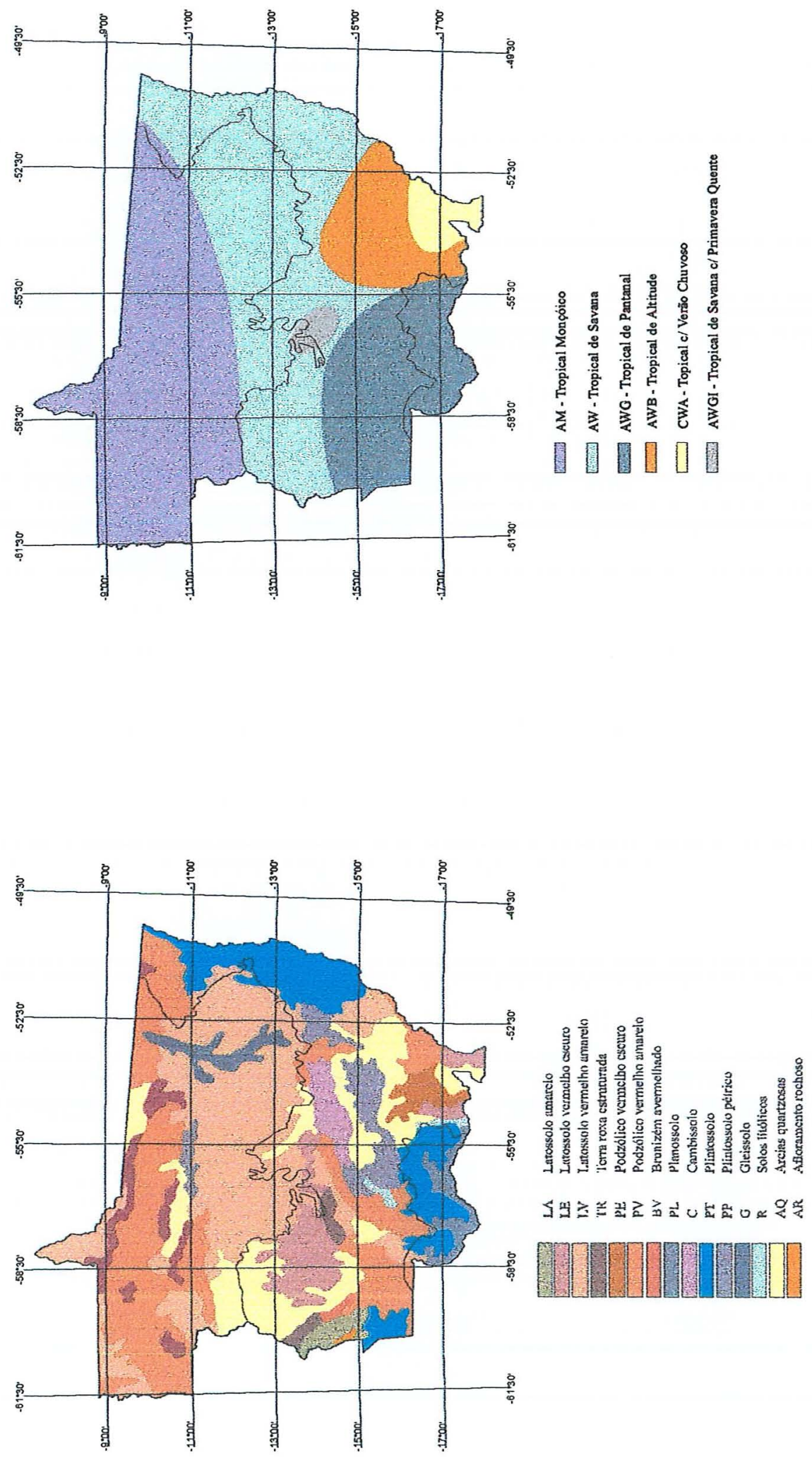

용ㅇ

ه 옹

焉

욤

몬

品

용

5

웡

茫

엉

요

;

뜽

年

氶

奇蛋舅

용 이

墕

哈

융

1) 党

응

8

요

\% 8

范

号它

记

苞芯

空

次 粦

웜

엉

员 :

के

종.․․․

势草

总范焉

这 


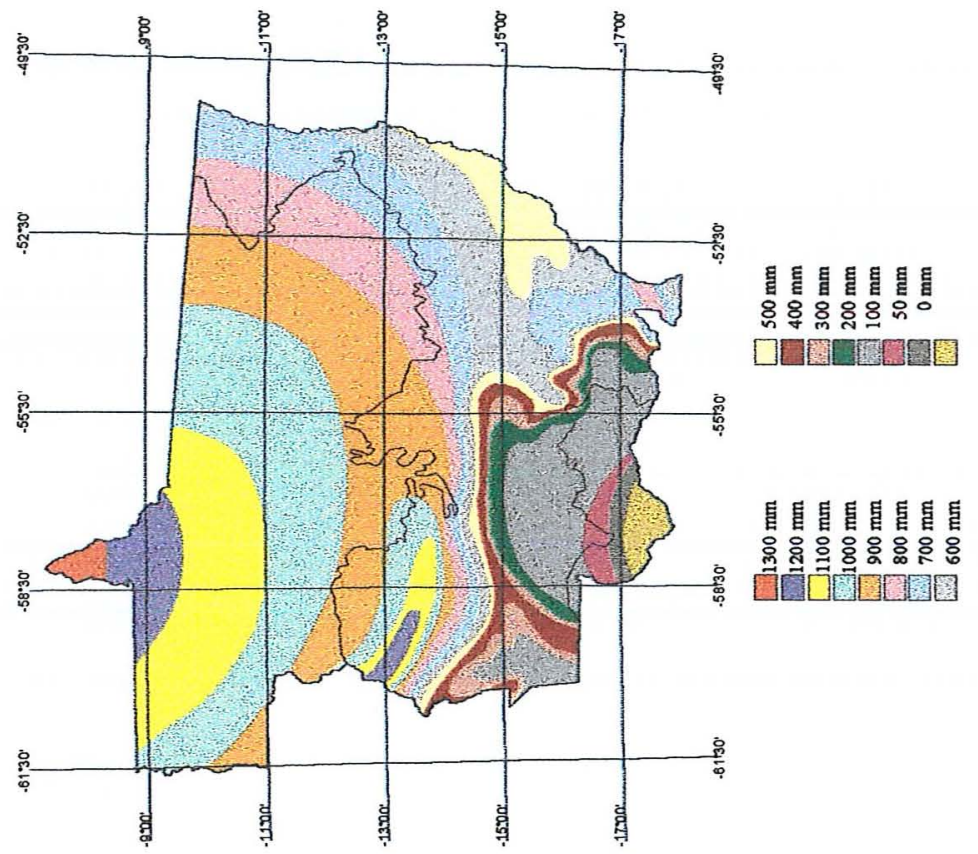

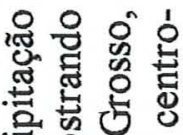

열열욜

बีే

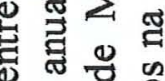

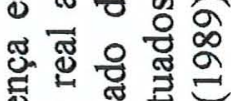

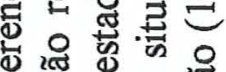

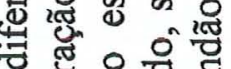

붕형

医융

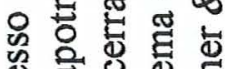

के

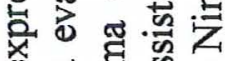

ช 웡

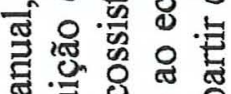

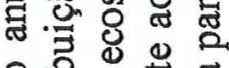

을

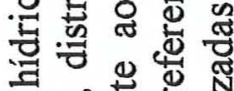

$\circ 0^{\circ} \mathrm{g}$

요욜

ठ원

응요

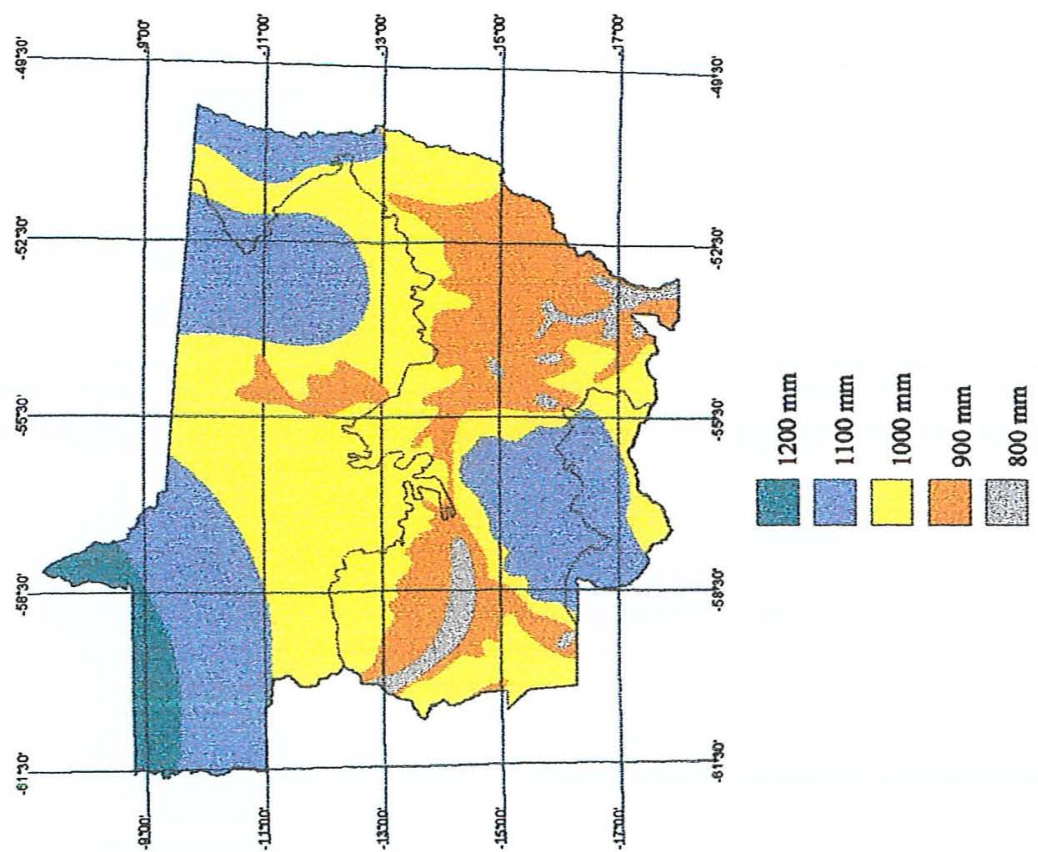

व

○ 300

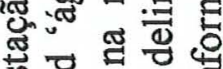

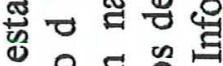

울 명잉

ช

远․ㅡㅁ

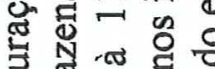

亏ै Ж

ช

용응

丞告焉

क्षे

c. ․․

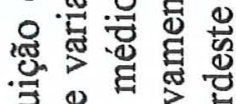

을 氙

㐘兽造

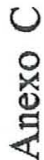


Anexo D - Descrição ${ }^{1}$ morfológica, mineralogia e micromorfológica do perfil do solo referente às parcelas experimentais.

Ap (0 - 15cm); bruno-avermelhado (5YR4/4); argiloso; fraca a moderada muito pequena a pequena granular; firável, ligeiramente plástico, ligeiramente pegajoso, transição gradual e plana, Areia Grossa: ( $86 \%$ de Quartzo + Quartzitos; $4 \%$ de nódulos/concreções ferruginosas + concreções manganosas; $3 \%$ de nódulos/concreções argilosas e/ou sílico-argilosas; $2 \%$ nódulos/concreções ferriargilosas ou argilo-ferruginosas; $5 \%$ Carvão + detritos; traços de Turmalina, Rutilo/IImenita, Muscovita, Magnetita (nas concreções) e fragmentos de rocha), Areia Fina: (92\% de Quartzo; 3\% de nódulos /concreções ferri-argilosas, argiloferruginosas; $2 \%$ nódulos/concreções ferruginosas + magnetita; $3 \%$ Carvão + detritos; Traços de Turmalina, Rutilo/IImenita, Zircão, Silica amorfa e fragmentos de rocha).

AB (15 - 40cm); vermelho-amarelado (5YR5/8); argiloso; fraca muito pequena a pequena granular; friável, ligeiramente plástico, ligeiramente pegajoso; transição difusa e plana, Areia Grossa: (88\% de Quartzo + Quartzitos; $7 \%$ de nódulos/concreções ferruginosas + concreções manganosas; $3 \%$ de nódulos/concreções argilosas e/ou sílico-argilosas; $2 \%$ de Carvão + detritos; Traços de Turmalina, Rutilo/limenita, Magnetita (nas concreções), Sílica amorfa e fregamentos de rocha), Areia Fina: (93\% de Quartzo; 3\% nódulos/concrę̧ões ferri-argilosas, argilo-ferruginosas; $2 \%$ nódulos/concreções ferruginosas + Magnetita; $2 \%$ Carvão + detritos; Traços de Turmalina, Rutilo/limenita, Zircão, Muscovita e Sílica amorfa).

BA $(40$ - 66cm); vermelho-amarelado (5YR5/8); argiloso; fraca muito pequena a pequena granular; friável, ligeiramente plástico; ligeiramente pegajoso; transição difusa e plana, Areia Grossa: (88\% de Quartzo + Quartzitos; $4 \%$ de nódulos/concreções ferruginosas + concreções manganosas; $3 \%$ nódulos/concreções ferri-argilosas ou argilo-ferruginosas; $2 \%$ nódulos/concreções argilosas e/ou sílico-argilosas; 3\% de Carvão + detritos; Traços de Turmalina, Magnetita (nas concreções), Sílica amorfa e fragmentos de rocha), Areia Fina: (93\% de Quartzo; 3\% de nódulos/concreções e ferruginosas + Magnetita; $2 \%$ nódulos/concreções ferri-argilosas/argilo-ferruginosas; $2 \%$ Carvão + detritos; Traços de Turmalina, Rutilo/IImenita, Zircão, Muscovita, Silica amorfa e Carvão.

\footnotetext{
${ }^{1}$ A descrição geral foi efetuada em 28/04/97 com as seguintes características: Situação, Declive e Cobertura Vegetal Sobre o Perfil: local com 4\% de declive, com presença de terraços, sem nenhuma cobertura vegetal: Altitude: 780 metros; Litologia: granitos intrusivos em rochas do Grupo Cuiabá; Formação Geológica: Granito de São Vicente; Período: Paleozóico - Cambro Ordoviciano; Material Originário: produto da intemperização de rochas graníticas; Pedregosidade e Rochosidade: ausente; Relevo Local: suave ondulado a ondulado; Erosão: não aparente; Drenagem: bem drenado; Vegetacão Primária: savana arbórea com floresta de galeria; Uso Atual: nenhum.
} 
Bw1 (66 - 87cm); vermelho (2,5YR5/8); argiloso; fraca pequena granular; friável; ligeiramente plástico; ligeiramente pegajoso; transição difusa e plana, Areia Grossa: $(88 \%$ de Quartzo + Quatzitos; $7 \%$ de nódulos/concreções ferruginosas; $3 \%$ de nódulos/concreções ferri-argilosas, argilo-ferruginosas; $2 \%$ de nódulos/concreções argilosas e/ou sílico-argilosas; Traços de Turmalina, Rutilo/IImenita, Muscovita, fragmentos de rocha xistosa com Muscovita, concreções manganosas e Carvão), Areia Fina: (95\% de Quartzo; 3\% de nódulos/concreções ferri-argilosas, argilo-ferruginosas; $1 \%$ de nódulos/concreções ferruginosas + Magnetita; $1 \%$ de nódulos/concreções argilosas e/ou sílicoargilosas; Traços de Turmalina, Rutilo/IImenita, Zircão, Muscovita, Sílica amorfa e Carvão).

Bw2 (87 - 120cm); vermelho (2,5YR4/8); argiloso; fraca pequena granular; friável; ligeiramente plástico; ligeiramente pegajoso; transição difusa e plana, Areia Grossa: ( $86 \%$ de Quartzo + Quartzitos; $8 \%$ de nódulos/concreções ferruginosas + concreções manganosas; $3 \%$ de nódulos/concreções ferri-argilosas, argilo-ferruginosas; $3 \%$ de nódulos/concreções argilosas e/ou silico-argilosas; Traços de Rutilo, Turmalina, Muscovita, fragmentos de rocha xistosa alterada, Sílica amorfa, Pirita oxidada e Carvão), Areia Fina: (95\% de Quartzo; $2 \%$ de nódulos/concreções ferruginosas; $2 \%$ de nódulos/concreções ferri-argilosas, argilo-ferruginosas; $1 \%$ de concreções sílico-argilosas e/ou argilosas; Traços de Turmalina, Rutilo/IImenita, Zircão, Muscovita, fragmentos de rocha e concreções manganosas)

Bw3 (120 - 160cm); vermelho (2,5YR4/8); argiloso; fraca pequena granular; friável; ligeiramente plástico; ligeiramente pegajoso, Areia Grossa: ( $86 \%$ de Quartzo + Quartzitos; $8 \%$ de nódulos/concreções ferruginosas + concreções manganosas; $4 \%$ de nódulos/concreções ferri-argilosas, argilo-ferruginosas; $2 \%$ de concreções Sílico-argilosas e argilosas; Traços de Turmalina, Muscovita, Pirita oxidada, Magnetita (nas concreções), fragmentos de rocha e Carvão), Areia Fina: (95\% de Quartzo; 3\% de nódulos/concreções ferri-argilosas, argilo-ferruginosas; $2 \%$ de nódulos/concreções ferruginosas + Magnetita; Traços de Turmalina, Rutilo/IImenita, Zircão, Muscovita, Sílica amorfa, concreções manganosas e fragmentos de rocha)

A descrição, a seguir, é com base na observação em ambas as frações, porém algumas características são melhor evidenciadas na fração areia grossa. Com relação às concreções (de todos os tipos) e aos fragmentos de rochas, na fração areia fina, são, simplesmente, fragmentos do mesmo material que ocorre na fração areia fina.

Quartzo: Grãos e fragmentos arredondados a subarredondados, esféricos e subesféricos, alguns tabulares, alguns com superficie lisa e brilhante, muitos com 
superficie fosca, em geral corroída ou com apenas indícios de corrosão, branco leitoso, rosado e hialino, alguns avermelhados e amarelados, por impregnação ferruginosas, muitos, contendo inclusões de opacos e incrustações ferruginosas.

Ocorrem alguns grãos de Quartzo tipo sacaróide, em agregados policristalinos, de cor branca e rosada a avermelhada.

Quartzitos: fragmentos subangulares alguns subarredondados, em geral tabulares. São agregados quartzosos alguns contendo Muscovita ou Sericita, inclusões de minerais opacos e incrustações ferruginosas, cor branca e rosada, também avermelhada por impregnações ferruginosas.

Nódulos/concreções ferruginosas: em geral de cor marrom escuro avermelhado, algumas cinza avermelhado, superficie polida brilhante (aspecto de verniz) algumas foscas predominantemente hematíticas, algumas também magnetíticas ou contendo Magnetita ( de 1 a $3 \%$ da amostra total).

Nódulos/concreções manganosas: em geral de cor marrom escuro a pretas, raramente polidas, em geral de aspecto terroso, algumas contendo quartzo incluso.

Nódulos/concreções ferri-argilosas ou argilo-ferruginosas: cores avermelhadas e rosadas, também amareladas, aspecto terroso, ou com superficie levemente polida, algumas contendo quartzo incluso. Algumas dessas, parecem ser fragmentos de rochas (Siltito/Metassiltito), concrecionários nódulos/concreções sílico-argilosas e argilosas: cor rosada clara a esbranquiçada e também rosada avermelhada.

Muscovita: ocorre em plaquetas, ou inclusas em fragmentos de rochas (xisto/quartzito), em geral branca transparente e límpida, algumas embaçadas em alteração, e também, avermelhadas por impregnações ferruginosas.

Fragmentos de rochas: ocorrem além das rochas já citadas (Quartzito, Siltito/Metassiltito), fragmentos de Xisto contendo Muscovita ou Sericita e Filito Sericitico, em geral alterados/em alteração.

Pirita oxidada: ocorre em forma de cubos, porém totalmente alterada, na realidade são pseudomorfos limoniticos. 


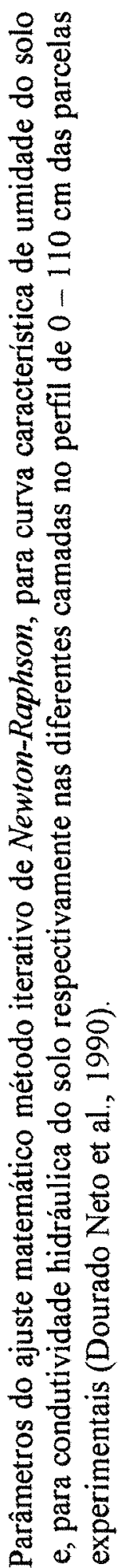
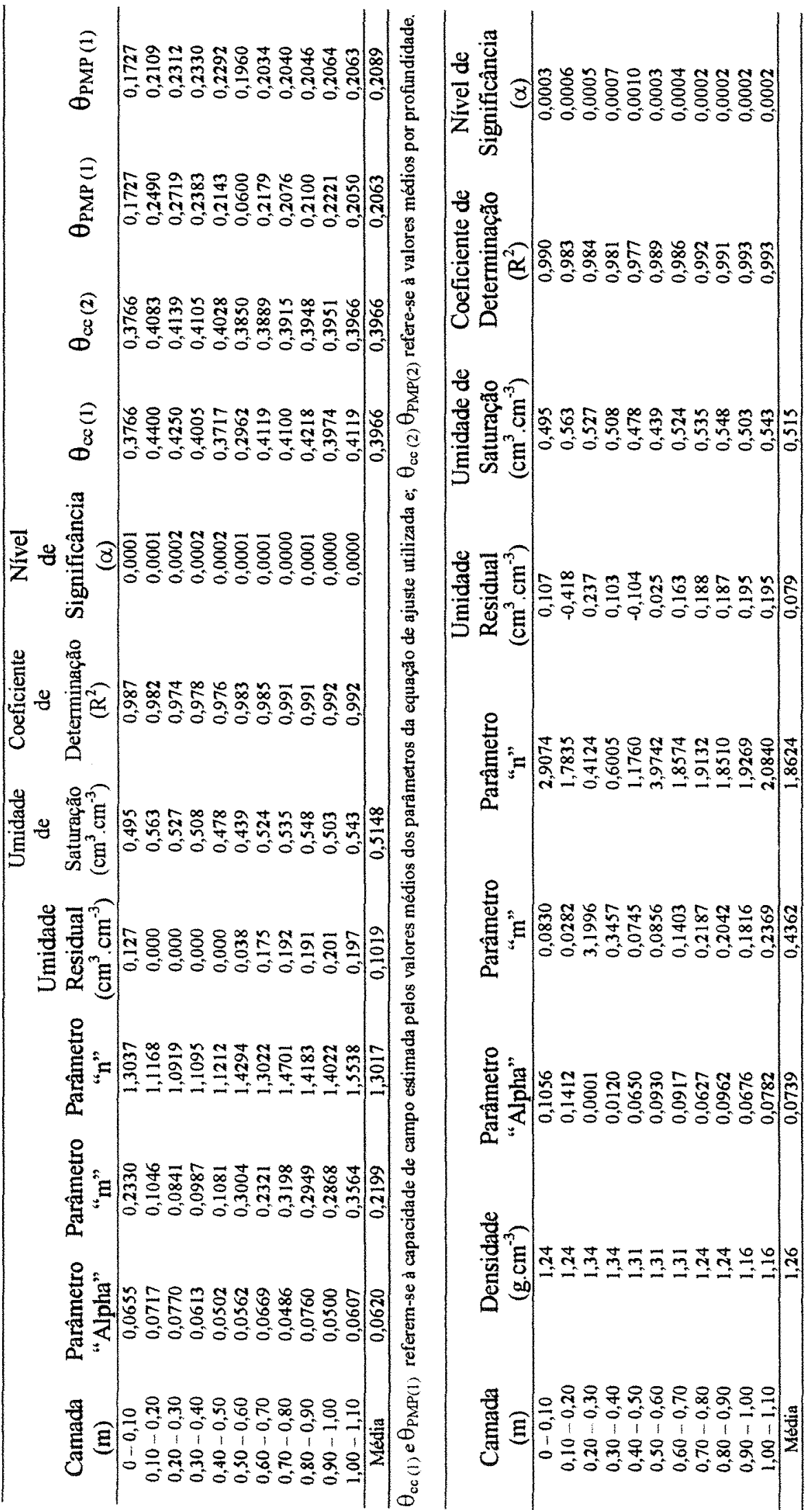
Anexo F - Quadros das análises de variâncias e respectivos parâmetros (graus de liberdade, soma de quadrado, quadrado médio e o teste de hipótese distribuição $F$ de Snedecor) para as variáveis estudadas.

\begin{tabular}{|c|c|c|c|c|c|}
\hline \multicolumn{6}{|c|}{ Variável - Indice de Área Foliar-IAF } \\
\hline $\begin{array}{c}\text { Causas da } \\
\text { Variação }\end{array}$ & $\begin{array}{l}\text { Graus de } \\
\text { Liberdade }\end{array}$ & $\begin{array}{l}\text { Soma de } \\
\text { Quadrado }\end{array}$ & $\begin{array}{l}\text { Quadrado } \\
\text { Médio }\end{array}$ & $\begin{array}{c}\text { Valor de } \\
F\end{array}$ & $\begin{array}{c}\text { Probabilidade } \\
>F\end{array}$ \\
\hline Blocos & 4 & 11,1822 & & & \\
\hline Material & 3 & 54,3102 & 18,1034 & 13,2345 & 0,00065 \\
\hline $\begin{array}{l}\text { Resíduo } \\
\text { (M) }\end{array}$ & 12 & 16,4147 & 1,3679 & & \\
\hline Parcelas & 19 & 81,9071 & & & \\
\hline Lâmina & 7 & 279,0601 & 39,8657 & 49,2962 & 0,00001 \\
\hline & & & & & \\
\hline Lâmina & 21 & 143,1053 & 6,8145 & 8,4266 & 0,00001 \\
\hline $\begin{array}{l}\text { Resíduo } \\
\text { (Lâmina) }\end{array}$ & 112 & 90,5741 & 0.8087 & & \\
\hline Total & 159 & 594,6467 & & & \\
\hline
\end{tabular}

\begin{tabular}{|c|c|c|c|c|c|}
\hline \multicolumn{6}{|c|}{ Variável - Intervalo de Florescimento Masculino-Feminino-IFMF } \\
\hline $\begin{array}{l}\text { Causas da } \\
\text { Variação }\end{array}$ & $\begin{array}{l}\text { Graus de } \\
\text { Liberdade }\end{array}$ & $\begin{array}{l}\text { Soma de } \\
\text { Quadrado }\end{array}$ & $\begin{array}{l}\text { Quadrado } \\
\text { Médio }\end{array}$ & $\begin{array}{c}\text { Valor de } \\
F\end{array}$ & $\begin{array}{c}\text { Probabilidade } \\
>F\end{array}$ \\
\hline Blocos & 4 & 871,4387 & & & \\
\hline Material & 3 & 5829,2263 & 1943,0754 & 20,9239 & 0,00014 \\
\hline Resíduo (M) & 12 & 1114,3682 & 92,8640 & & \\
\hline Parcelas & 19 & 7815,0332 & & & \\
\hline Lâmina & 7 & 22096,1500 & 3156,5929 & 61,2908 & 0,00001 \\
\hline Mat & & & & & \\
\hline Lâmina & 21 & 29809,0046 & 1419,4764 & 27,5616 & 0,00001 \\
\hline $\begin{array}{l}\text { Resíduo } \\
\text { (Lâmina) }\end{array}$ & 112 & 5768,2134 & 51,5019 & & \\
\hline Total & 159 & 65488,4013 & & & \\
\hline
\end{tabular}

\begin{tabular}{lccccc}
\hline \multicolumn{7}{c}{ Variável - Índice de Colheita-IC } \\
\hline $\begin{array}{l}\text { Causas da } \\
\text { Variação }\end{array}$ & $\begin{array}{c}\text { Graus de } \\
\text { Liberdade }\end{array}$ & $\begin{array}{c}\text { Soma de } \\
\text { Quadrado }\end{array}$ & $\begin{array}{c}\text { Quadrado } \\
\text { Médio }\end{array}$ & $\begin{array}{c}\text { Valor de } \\
F\end{array}$ & $\begin{array}{c}\text { Probabilidade } \\
>F\end{array}$ \\
\hline $\begin{array}{l}\text { Blocos } \\
\text { Material }\end{array}$ & 3 & 0,0041 & & & \\
Resíduo (M) & 12 & 0,1832 & 0,0611 & 26,0138 & 0,00007 \\
\hline Parcelas & 19 & 0,0282 & 0,0023 & & \\
\hline Lâmina & 7 & 0,2155 & & 16,4803 & 0,00001 \\
$\begin{array}{l}\text { Mat } \\
\text { Lâmina }\end{array}$ & 21 & 0,4159 & 0,0198 & 8,9697 & 0,00001 \\
$\begin{array}{l}\text { Resíduo } \\
\text { Lâmina) }\end{array}$ & 112 & 0,2473 & 0,0022 & & \\
\hline Total & 159 & 1,1334 & & \\
\hline Média geral: 0,3869, CV (Material): $4,427 \%$, CV (Lâmina): $12,144 \%$ & & \\
\hline
\end{tabular}


Continuação Anexo F ...

\begin{tabular}{|c|c|c|c|c|c|}
\hline \multicolumn{6}{|c|}{ Variável - Pproducão de Grãos-PG } \\
\hline $\begin{array}{l}\text { Causas da } \\
\text { Variação }\end{array}$ & $\begin{array}{l}\text { Graus de } \\
\text { Liberdade }\end{array}$ & $\begin{array}{l}\text { Soma de } \\
\text { Quadrado }\end{array}$ & $\begin{array}{l}\text { Quadrado } \\
\text { Médio }\end{array}$ & $\begin{array}{c}\text { Valor de } \\
F \\
\end{array}$ & $\begin{array}{c}\text { Probabilidade } \\
>F\end{array}$ \\
\hline Blocos & 4 & 828614,3393 & & & \\
\hline Material & 3 & 15819943,25 & 5273314,4167 & 13,7308 & 0,00057 \\
\hline Resíduo (M) & 12 & 4608604,884 & 384050,4070 & & \\
\hline Parcelas & 19 & 21257162,47 & & & \\
\hline Lâmina & 7 & 381377710,4 & 54482530,063 & 102,7289 & 0,00001 \\
\hline Mat & & & & & 0,00034 \\
\hline Lâmina & 21 & 31782077,33 & 1513432,2536 & 2,8536 & \\
\hline $\begin{array}{l}\text { Resíduo } \\
\text { (Lâmina) }\end{array}$ & 112 & 59399470,35 & 530352,4138 & & \\
\hline Total & 159 & 493816420,6 & & & \\
\hline
\end{tabular}

\begin{tabular}{|c|c|c|c|c|c|}
\hline \multicolumn{6}{|c|}{ Variável - Coeficiente de Resposta-Ky } \\
\hline $\begin{array}{c}\text { Causas da } \\
\text { Variação }\end{array}$ & $\begin{array}{c}\text { Graus de } \\
\text { Liberdade }\end{array}$ & $\begin{array}{c}\text { Soma de } \\
\text { Quadrado }\end{array}$ & $\begin{array}{l}\text { Quadrado } \\
\text { Médio }\end{array}$ & $\begin{array}{c}\text { Valor de } \\
F\end{array}$ & $\begin{array}{c}\text { Probabilidade } \\
>F\end{array}$ \\
\hline Blocos & 4 & 0,0770 & & & \\
\hline Material & 3 & 31,7831 & 10,5944 & 330,1494 & 0,00001 \\
\hline Resíduo (M) & 12 & 0,3851 & 0.0321 & & \\
\hline Parcelas & 19 & 32.2451 & & & \\
\hline Lâmina & 7 & 172,9928 & 24,7133 & 521,4515 & 0,00001 \\
\hline Mat & & & & & 0,00001 \\
\hline Lâmina & 21 & 64,0210 & 3,0486 & 64,3261 & \\
\hline $\begin{array}{l}\text { Resíduo } \\
\text { (Lâmina) }\end{array}$ & 112 & 5,3080 & 0.0474 & & \\
\hline Total & 159 & 274.5670 & & & \\
\hline
\end{tabular}

\begin{tabular}{|c|c|c|c|c|c|}
\hline \multicolumn{6}{|c|}{ Variável-Altura das Plantas-AP } \\
\hline $\begin{array}{l}\text { Causas da } \\
\text { Variação }\end{array}$ & $\begin{array}{c}\text { Graus de } \\
\text { Liberdade }\end{array}$ & $\begin{array}{c}\text { Soma de } \\
\text { Quadrado }\end{array}$ & $\begin{array}{l}\text { Quadrado } \\
\text { Médio }\end{array}$ & $\begin{array}{c}\text { Valor de } \\
F\end{array}$ & $\begin{array}{c}\text { Probabilidade } \\
>F\end{array}$ \\
\hline Blocos & 4 & 0,0900 & & & \\
\hline Material & 3 & 0,0591 & 0,01970 & 1,7428 & 0,21091 \\
\hline Resíduo (M) & 12 & 0,1357 & 0,01130 & & \\
\hline Parcelas & 19 & 0.2848 & & & \\
\hline Lâmina & 7 & 2,2854 & 0,32649 & 72,3805 & 0,00001 \\
\hline Mat & & & & & \\
\hline Lâmina & 21 & 0,7452 & 0,03549 & 7,8675 & 0,00001 \\
\hline Resíduo & & & & & \\
\hline (Lâmina) & 112 & 0,5052 & 0,00451 & & \\
\hline Total & 159 & 3,8206 & & & \\
\hline
\end{tabular}




\section{REFERÊNCIAS BIBLIOGRÁFICAS}

ALFONSI, R. R. Épocas de semeadura para a cultura do milho (Zea mays L.) no Estado de São Paulo, baseado na probabilidade do atendimento hídrico em fases fenológicas críticas. Piracicaba, 1996. 141p. Tese (Doutorado) - Escola Superior de Agricultura "Luiz de Queiroz", Universidade de São Paulo.

ALLEN, L. H.; YOCUM, C. S.; LEMON, E. R. Photosynthesis under field conditions. VII. Radiant energy exchanges within a corn crop canopy and implications in water use efficiency. Agronomy Journal, v.56, p.235-259, 1964.

ALLISON. J. C. S.; DAYNARD, T. B. Effect of change in time of flowering, induced by altering photoperiod or temperature, on attributes related to yield in maize. Crop Science, v. 19, n.1, p.1-4, Jan./Feb. 1979.

ANDRADE, D. L. T.; SEDIYAMA, G. C.; COUTO, L.; SANS, L. M. A., FERREIRA, P. A. Balanço hídrico num latossolo vermelho-escuro álico cultivado com milho com irrigação por aspersão. Revista Ceres, v.95, n.197, p.89-104, 1988.

ARAGON, E. L.; DE'DATTA, S. K. Drought response of rice at different nitrogen levels using source sprinkler system. Irrigation Science, v.3, n.2, p.63-73, April. 1981.

ASPIAZÚ, C.; SHAW, R. H. Comparison of several methods of growing-degree-unit calculation for corn (Zea mays L.). Journal of Science, v.46, n.4, p.435-42, 1972.

BARBOSA, J. A. Influência de espaçamento e arquitetura foliar no rendimento de grãos e outras características agronômicas do milho (Zea mays L.). Lavras, 1995. 48p. Dissertação (M.S.) - Universidade Federal de Lavras.

BASSETTI, P.; WESTGATE, M. E. Water deficits affects receptivity of maize silks. Crop Science, v.33, n.2, p.279-282, 1993. 
BEGG, J. E.; TURNER, N. C. Crop water deficits. Advances in Agronomy, v.28, p.161-217, 1976.

BERLATO, M. A.; SUTILI, V. R. Determinação das temperaturas bases dos subperíodos emergência - pendoamento e energência - espigamento de 3 cultivares de milho. In: XXI REUNIÃO TÉCNICA DE MLHO E SORGO. Resumos. Porto Alegre. p.26., 1976.

BERLATO, M. A.; MATZENAUER, R.; SUTILI, V. R. Relações entre temperatura e o aparecimento de fases fenológicas do milho (Zea mays L.). Agronomia Sulriograndense, v.20, n.1, p.111-32, 1984.

BERNARDES, L. R. M. Datas de florescimento de duas cultivares de milho (Zea mays L.) no Estado do Paraná em função da emergência. In: CONGRESSO BRASILEIRO DE AGROMETEOROLOGIA, Maceió, 1969. Anais. Maceió: Sociedade Brasileira de Agrometeorologia, 1989. p.106-111.

BERNARDES, L. R. M.; BOOTSMA, A.; CHAPUT, D.; GOMES, J. C. Comparação de dois métodos de estimativas de unidades de calor para florescimento e maturação de cinco cultivares de milho (Zea mays L.) no Estado do Paraná. In: CONGRESSO BRASILEIRO DE AGROMETEOROLOGIA, 5, Belém, 1987. Coletâneas de trabalhos. Belém: Sociedade Brasileira de Agrometeorologia, 1987. p.110-114.

BERNARDO, S. Manual de irrigação. Viçosa: Universidade Federal de Viçosa, 1982. 464p.

BOLAÑOS, J. A.; EDMEADES, G. O Maize breeding for drought tolerance. In: INTERNATIONAL SYMPSIUM ON ENVIRONMENTAL STRESS: MAIZE IN PERSPECTIVE, Sete Lagoas, 1995. Anais. Sete Lagoas: EMBRAPA/CNPMS, 1995. 449p.

BOYER, J. S. Water deficits and photosynthesis. In: KOZLOWSKI, T. T. Water deficits and plant growth. New York: Academic Press, 1976. v.4.

BRAUNWORTH Jr., W. S.; MACK Jr., H. J. Crop: water production functions for sweet com. Journal of the American Society for Horticultural Science, v.114, n.2, p. $210-215,1989$.

BREVEDAN, E. R.; HODGES, H. F. Effects of moisture deficitis in ${ }^{14} \mathrm{C}$ translocation in corn (Zea mays L.). Plant Physiology, v.52, p.436-439, 1973.

BRITO, A. R. M. B. Comportamento de híbridos de milho tardio precoce e superprecoce na época de "safrinha", submetidos a diferentes níveis de nitrogênio. Piracicaba, 1995. 78p. Dissertação (M.S.) - Escola Superior de Agricultura "Luiz de Queiroz", Universidade de São Paulo. 
BROWN, D. M. Heat units for corn in southein Ontario. Ontário, Departament of Agricultural and Food. AGDEX, 1969. 4p. (Informatio Leaflet AGDEX III/31).

BRUNINI, O. Ecologia do milho e da soja. In: SIMPÓSIO SOBRE SISTEMA DE PRODUÇÃO AGRÍCOLA, Campinas, 1984. Resumos. Campinas: Fundação Cargill, 1984. p.26-70.

BRUNINI, O., ALFONSI, A. A., CAMARGO, M. B. P. Efeito dos elementos climáticos no desenvolvimento da cultura do milho. In: SIMPÓSIO SOBRE PRODUTIVIDADE DO MILHO, Londrina, 1983. Anais. Londrina: IAPAR, 1983. p.21-39.

BRUNINI, O.; CAMARGO, M. B. P.; MIRANDA, L. T.; SAWASAKI, E. Resistência estomatal e potencial de água em variedades de milho em condições de campo. In: CONGRESSO BRASILEIRO DE AGROMETEOROLOGIA, 3., Pelotas, 1981. Resumos. Pelotas, 1981. p.134-138.

BUREN, L. L.; MOCK, J. J.; ANDERSON, I. C. Morfhological and physiological traits in maize associated with tolerance to high plant density. Crop Science, v.3, n.14, p.426-429, 1974.

CALVACHE ULLOA, A. M; LIBARDI, P. L.; REICHARDT, K. Utilização do nitrogênio por dois híbridos de milho. Campinas: Fundação Cargill, 1982. 66p.

CAMPELO JÚNIOR, J. H.; CASEIRO, F. T. Métodos de estimativa da evapotranspiração potencial. Cuiabá: FUFMT, 1989. 160p. (Relatório de Pesquisa - Universidade Federal de Mato Grosso).

CARDOSO, M. J. ; MUNDSTOCK, C. M. Comparação de treze métodos de cálculo de unidades térmicas de desenvolvimento de milho (Zea mays L.). Ciência e Cultura SBPC, v.11, n.31, p.1278-1283, 1979.

CARSON, P. L.; WARD, R. C.; SHANK, D. B.; BEATTY, D. W. Stale corn yields sought in Northem Great Plaints. Crop and Soils Magazine, n. 19, p.297-300, 1966.

CASTRO, P. T. Evapotranspiração atual e potencial de uma cultura de milho (Zea mays L.). Piracicaba, 1979. 61p. Dissertação (M.S.) - Escola Superior de Agricultura "Luiz de Queiroz", Universidade de São Paulo.

CODY, M. L. A general theory of dutch size evolution. Lawrence, v. 20, p. 174-184. 1966.

COELHO, D. T.; DALE, R. F. An energy-crop variable and temperature function for predction corn growth and development: planting to silking. Agronomy Journal, v.3, n. 72 , p.503-510, 1980. 
COSCULLUELA, F.; FACI, J. M. Development of water production of corn (Zea mays L.) by the use of a line-source sprinkler. Investigacion Agraria Produccion $\mathbf{y}$ Proteccion Vegetales, v.2, n.7, p.169-194, Aug. 1992.

COSTA, A. F. S. Influência das condições climáticas no crescimento e desenvolvimento de plantas de milho (Zea mays L.), avaliadas em diferentes épocas de plantio. Viçosa, 1994. 109p. Tese (Doutorado) - Universidade Federal de Viçosa.

COUTO, L.; COSTA E. ; GARCIA, J. C. Função de produção e eficiência no uso da água pela cultura do milho. In: REUNIÃO TÉCNICA ANUAL DO MILHO, 26., Porto Alegre, 1981. Ata. Porto Alegre: IPAGRO, 1981. p.105-108.

CRAFTS, A S. Water deficits and physiological process. In: KOZLOWSKI, T. T. (Ed.) Water deficits ana plants growth. New York: Academic Press, 1968. v.2, p.85133.

CROSS, H. A.; ZUBER, M. S. Prediction of flowering dates in maizwe based on different methods of estimating thermal units. Agronomy Journal, v.64, p.351-355, 1972.

CROSS, H. Z.; TONYEKAMEN, J.; BRUN, L. Plant density, maturity and prolificacy affects on early maize. Canadian Journal of Science, v.67, p.35-42, 1987.

CUNHA, G. R. DA. Evapotranspiração e função de resposta a disponibilidade hídrica em alfafa. Porto Alegre, 1991. 197p. Tese (Doutorado) - Universidade Federal do Rio Grande do Sul.

DAVIDSON, R. L. Effects of soil nutrients and moisture on root/shoot ratios in solium perene L. and Trifolium repens L. Ann. Bot, v. 33, p.571-577, 1969.

DAYNARD, T. B.; DUNCAN, W. G. The black layer grain maturity in corn. Crop Science, n.9, p.473-476, Jul./Aug. 1969.

DENMEAD, O.T.; SHAW, R. H. The efects of soil moisture stress at different stages of growth on the development and yield of corn. Agronomy Journal, v.52, n.5, p.272$274,1960$.

DENMEAD, O.T.; SHAW, R. H. Availability of soil water to plants as caffeeted by soil moisture content and meteorological conditions. Agronomy Journal, v.5, n.54, p.385-390, 1962.

DOMENACK, C.M.R. Balanço da radiação solar das ondas curtas em três densidades de plantio de milho. var. Cargill 501. Piracicaba, 1980. 78p. Dissertação (M.S.) Escola Superior de Agricultura "Luiz de Queiroz" - Universidade de São Paulo. 
DONALD, C. M.; HAMBLIN, J. The biological yield and harvest index of cereals as agronomic and plant breeding criteria. Advances in Agronomy, v.28, p.361-405, 1976.

DOORENBOS, J.; KASSAM, A. H. Yield response to water. Roma: FAO, 1979. 193p. (FAO Irrigation \& Drainage Paper, n. 24).

DOSS, B. D. Comparison of fog irrigation with surface irrigation in corn production. Agronomy Journal, v.66, p. 105-106, 1974.

DOUGLAS, W. S.; DWYER, L. M.; CARRIGAN, L. L. Phenological temperature response of maize. Agronomy Journal, v.90, Jan./Feb. 1998.

DOURADO NETO, D; JONG VAN LIER, Q.; BOTREL, T. A.; LIBARDI, P.L. Programa para confecção da curva de retenção de água no solo utilizando o modelo de van Genuchten. Engenharia Rural, v.1, n.2, p.92-102, 1990.

DOW, E. W.; DAYNARD, T. B.; MULDROON, J. F.; MAJOR, D. J.; THURTELL, G. W. Resistance to drought and dẹnsity stress in Canadian and European maize (Zea mays L) hydrids. Canadian Journal Plant Science, v.64, p.575-585, 1984.

DUNCAN, W.G. Plant relationship between corn population and yield. Agronony Journal, v.50, p.52-54, 1958.

DUNCAN, W. G. Cultural manipulation for higher yields. In: EASTIN, J. D. ; HASKINS, F. A.; SUlliVAN, C. Y.; BAVEL, C. H. M. van. (Ed.). Physiological aspects of crop yield. Madison: American Society of Agronomy, 1969. p.327-342.

DURÃES, F. O M. Fatores ecofisiológicos afetando o comportamento de milho em semeadura tardia (safrinha) no Brasil Central. Piracicaba, 1993. 91p. Tese (Doutorado) - Escola Superior de Agricultura "Luiz de Queiroz"- Universidade de São Paulo.

DURÃES, F. O. M.; PAIVA, E.; MAGALHÃES, P. C.; SANTOS, M. X. do; PEREIRA, J. J.; LABORY, C. R. G. Critérios morfo-físiológicos para seleção de genótipos de milho visando tolerância à seca. In: CONGRESSO BRASILEIRO DE FISIOLOGIA VEGETAL, 4. Belém, 1997. Resumos. Belém, 1997.

EDMEADES, G. O.; BOLAÑOS, J.; HERNANDEZ, M.; BELLO, S. Underlyng causes of the reduction in the Anthesis-Silking Interval in drought tolerant tropical maize. Agronomy Abstracts, Annual Meetings, p.15-20, oct. 1989.

EDMEADES, G. O.; DAYNARD, T. B. The development of plant-to-plant variability in maize at different planting densities. Canadian Journal Plant Science. v.59, p.561576,1979 
EMPRESA BRASILEIRA DE PESQUISA AGROPECUÁRIA. Serviço de Produção e Informação. Recomendações técnicas para o cultivo do milho. Brasilia: EMBRAPA, 1993. 204p.

EMPRESA BRASILEIRA DE PESQUISA AGROPECUÁRIA. Departamento de Estudos e Pesquisas. Diagnóstico e prioridades de pesquisa em agricultura irrigada: região Centro-Oeste. Brasília: EMBRAPA, 1988. 132p.

EMPRESA MATOGROSSENSE DE PESQUISA, ASSISTÊNCIA E EXTENSÃO RURAL. Anuário Agropecuário e Agroindustrial de Mato Grosso. Cuiabá: EMPAER-MT, 1997. 429p.

ENDRES, V. C.; MUNDSTOCK, C. M. Evolução da àrea foliar e duração do período de formação dos grãos de três híbridos de milho em duas épocas de semeadura. Pesquisa Agropecuária Brasileira, v.24, n.4, p.455-459, 1989.

ESPINOZA, W. Resposta de doze cultivares de milho ao déficit hídrico num latossolo vermelho-escuro (typic hapl orthox) de cerrados do Distrito Federal. Pesquisa Agropecuária Brasileira, v.17, n.6, p.905-915, 1982.

EVANS, L. T. Crop Physiology: some case histories. London: Cambridge University Press, 1975. 374p.

FANCELLI, A L. Milho: produção, pré-processamento e transformação agroindustrial. São Paulo: Secretaria da Indústria, Comércio, Ciência e Tecnologia, 1986. 112p. (Extensão Agroindustrial, 5).

FARIA, R. T. Estudo da lâmina de irrigação na cultura do trigo (Triticum aestivum, L.) utilizando o sistema de aspersão em linha. Piracicaba, 1981. 71p. Dissertação (M.S.) - Escola Superior de Agricultura "Luiz de Queiroz", Universidade de São Paulo.

FARIA, R. T.; OLITTA, A. F. L. Lâmina de irrigação na cultura do trigo utilizando o sistema de aspersão em linha. Pesquisa Agropecuária Brasileira, v.22, n.9-10, p.999-1008, set./out. 1987.

FERREIRA, V. M. Aspectos de crescimento, nutrição e relações hídricas em dois genótipos de milho (Zea mays L.) em função da disponibilidade de água no solo. Lavras, 1997. 100p. Dissertação (M.S.) - Universidade Federal de Lavras.

FERNANDEZ, G. C. J. Repeated measure analysis of line source sprinkler experiments. Hort Science, v.26, p.339-342, 1991. 
FERNANDEZ, G. C. J. Repeated measure analysis of line source sprinkler experiments. Hort Science, v.26, p.339-342, 1991.

FOLEGATTI, M. V. Avaliação do desempenho de um "scheduler"na detecção do estresse hídrico em cultura do feijoeiro (Phaseolus vulgaris, L.) irrigada com diferentes lâminas. Piracicaba, 1988. 188p. Tese (Doutorado) - Escola Superior de Agricultura "Luiz de Queiroz", Universidade de São Paulo.

FORNASIERI FILHO, D. A cultura do milho. Jaboticabal: FUNEP, 1992. 273p.

FRANCIS, C. A.; RUTGER, J. N.; PALMER, A. F. E. A rapid method for plant leaf area estimation in maize (Zea mays L.). Crop Science, v.9, n.5, p. 537-539, Set./Out. 1969.

FRIZZONE, J. A. Funções de resposta do feijoeiro (Phaseolus vulgaris L.) ao uso de nitrogênio e lâmina de irrigação. Piracicaba, 1986. 113p. Tese (Doutorado) - Escola Superior de Agricultura "Luiz de Queiroz", Universidade de São Paulo.

FUNDAÇÃO INSTITUTO AGRONÔMTCO DO PARANÁ. A cultura do milho no Paraná. Londrina: IAPAR, 1991. 270p.

FUNDAÇÃO INSTITUTO BRASILEIRO DE GEOGRAFIA E ESTATÍSTICA. Censo agropecuário. Rio de Janeiro: FIBGE, 1997. n.24, 231p.

GARCIA, A. G. y; OLIVEIRA, O. J.; DOURADO NETO, D. Determinação do fator de forma da curva de crescimento do sistema radicular da cultura de milho (Zea mays L.) (compact disc). In: CONGRESSO BRASILEIRO DE ENGENHARIA AGRICOLA, 26., Campina Grande, 1997. Anais. Campina Grande: SBEA, 1997.

GARCIA, B. I. L. Determinação de temperatura-base e influência de variáveis climáticas na duração do ciclo e na produção do milho. Piracicaba, 1993. 82p. Dissertação (M.S.) - Escola Superior de Agricultura "Luiz de Queiroz", Universidade de São Paulo.

GARDNER, W. R. Dynamics aspects of water availability to plants. Soil Science, v. 89, n. 2, p. $63-73,1960$.

GENUCHTEN, M. T. van. A closed-form equation for predictings the hydraulic conductivity of unsaturated soils. Soil Science Society of America Journal, v. 41, p. $892-898,1980$.

GENUCHTEN, M. T. van; NIELSEN, D. R. On describing and predicting the hydraulic properties of unsaturated soils. Annales Geophysical, v. 3, n 5, p.615-628, 1985. 
GILMORE, E. C.; ROGERS, J. S. Heat units as a method of measuring maturity in corn. Agronomy Journal, v. 50, p.611-615, 1958.

GOLDSWORTHY, P. R; COLEGROVE, M. Growth an yield of higland maize in Mexico. Journal of Agriculture Science, v.83, p.213-221, 1974.

GOLDSWORTHY, P. R.; PALMER, A. F. E.; SPERLING, D. W. Growth and yield of low tropical maize in México. Journal of Agricultural Science, v.83, p.223-230, 1974.

HANKS, R. J. Model for predicting plant yield as influenced by water use. Agronomy Journal, v.66, p. 660-665, 1974.

HANKS, R. J.; KELLER, J.; RASMUSSEN V. P.; WILSON, G. D. Line source sprinkler for continuous variable irrigation: crop production studies. Soil Science Society of American Journal, v.40, n.3, p.426-429, 1976.

HANKS, R. J.; SISSON, D. V.; HURTS, R. L.; HUBBARD, K. G. Statistical analysis of results from irrigation experiments using the line source sprinkler system. Journal of the Soil Science Society of America, v.44, n.4, p.886-888, 1980.

HANSON, A D. ; HITZ, W. D. Metabolic responses of mesophytes to plant water deficits. Annual Review of Plant Physiology, v.33, p.163-203, 1982.

HERRERO, M. P.; JOHNSON, R. R. Drought stress and its effects on maize reproductive systems. Crop Science, v.21, p.105-110, 1981.

HODGES, T. Predicting crop phenology. Boca Raton: CRC Press, 1991. p.115-131.

HOFFMAN, G. J.; RAWLINS, S. L.; GARBER, M. J.; CULLEN, E. M. Water relations and growth of cotton as influenced by salinity and relative humidy. Agronomy Journal, v.63, p.822-826, 1971.

HOWELL, T. A.; TOLK, J. A.; SCHENEIDER, A. D.; EVETT, S. R. Evapotranspiration, yiels, and water use efficiency of corn hybrids differing maturity. Agronomy Journal, v.90, p.3-9, Jan./Feb., 1998.

HSIAO, T. C. Plant responses to water stress. Annual Review of Plant Physiology, v.24, p.518-570, 1973.

HSIAO, T. C.; ACEVEDO, E. Plant response to water deficits, water use efficincy snd draught resistance. Agriculture Meteorology, v. 14, p.59-84, 1974. 
ISMAIL, S. M. Sprinkler irrigated wheat production function ad mathematicam optimization. Alexandria Journal of Agricultural Research, v.38, n.3, p.51-69, 1993.

JENSEN, M.E. Consuptive use of water and irrigation water requirements. New York: ASCE, 1974. 215p.

JONG, S. K.; BREWBAKER, J. L.; LEE, C. H. Effects of solar radiation on the performance of maize in 41 sucessive monthly plantings in Hawaii. Crop Science, v. 22, p. $13-18,1982$.

KAGE, H. Adubação verde: as observações de um lavrador. In: FUNDAÇÃO CARGILL. Adubação orgânica: adubação verde e rotação de culturas no Estado de São Paulo. Campinas: Fundação Cargill, 1983. p.113-148.

KRAMER, P.J. Relaciones hidrica de suelos y plant ureia sintesis moderna (Plant and soil water relationship a modern syntheses). México: Idictex, 1969. 538p.

KRAMER, P.J. Fifty years of progress in water relations reasearch. Plant Physiology, v.54, p.463-471, 1974.

KÖEPPEN, W. Climatologia: com un estudio de los climas de la tierra. Pánuco: Fondo de Cultura Econômica, 1948, 478p.

LANCHER, W. Physiological ecology. Berlin: Springer Verlag, 1975. 272p.

LEITE, P. J. S. Respostas correlacionadas à seleção divergente para florescimento em um composto de milho (Zea mays L.). Piracicaba, 1985. 55p. Dissertação (M.S.) Escola Superior de Agricultura "Luiz de Queiroz", Universidade de São Paulo.

LIBARDI, P. L. Dinâmica da água no solo. Piracicaba: Paulo Leonel Libardi, 1995. $497 \mathrm{p}$.

LIBARDI, P. L.; SAAD, A. M Balanço hídrico em cultura de feijão irrigada por pivô central em latossolo roxo. Revista Brasileira de Ciência do Solo, v.18, p.529-532, 1994.

LOPES, N. F.; MAESTRI, M. Crescimento, morfologia, partição de assimilados e produção de matéria seca do milho (Zea mays L.) cultivado em três densidades populacionais. Revista Ceres, v.28, n.157, p. 268-288, 1981.

MACHADO, E.C.; PEREIRA, A. R.; FAHL, J. I.; ARRUDA, H. V.; SILVA, W. J. da; TEIXEIRA, J. P. F. Análise quantitativa de crescimento de quatro variedades de milho em três densidades de plantio, através de funções matemáticas ajustadas. Pesquisa Agropecuária Brasileira, v. 17, n.6, p.825-833, jun. 1982. 
MACHADO, E. C.; FURLANI, P. R; HANNA, L. G.; CAMARGO, M. B. P.; BRUNINI, O.; MAGALHÃES, H. H. S. Características biométricas e fisiológicas de três cultivares de milho. Bragantia, Campinas, v.44, n.1, p.283-294. 1985.

MACKINNON, J. C. Energy allocation during growth of six maize hybrids in nova scotia. Canadian Journal Plant Science, v.59, p.667-677, 1979.

MALUF, J.R.T.; MALTLENAUER, R; CUNHA, G.R da; WESTPHALEN, S.L. Agroclimatologia do Estado do Rio Grande do Sul II: zoneamento agroclimático da cultura do milho. Porto Alegre: IPAGRO INFORMA, v.26, p.3-12, 1983.

MAGALHÃES, A. C. N. Análise quantitativa do crescimento. In: FERRI, M. G. Fisiologia Vegetal I. São Paulo: EPV/EDUSP, 1979. v.1, p.331-50.

MAGALHÃES, A. C.; SILVA, W. J. Determinantes genético-fisiológicos da produtividade do milho. In: PATERNIANI, E. Melhoramento e produção do milho no Brasil. Campinas: Fundação Cargill, 1987. v.2, p.346-379.

MAGAlHÃES, P. C.; DURÃES, F. O. M.; PAIVA, E. Fisiologia da planta de milho. Sete Lagoas: EMBRAPA/CNPMS, 1995. 27p.

McKEE, G. W. A coefficienty for computing leaf area in hibrid corn. Agronomy Journal, v.56, p.240-241, 1964.

MENDONÇA, F. C. Adubação nitrogenada na cultura do milho aplicada por um sistema de aspersão em linha. Piracicaba, 1994. 60p. (Dissertação (M.S.), Escola Superior de Agricultura "Luiz de Queiroz", Universidade de São Paulo.

MORGAN, D. D. V.; CARR, M. K. V. Analysis of experiments involving line source sprinkler irrigation. Experimental Agriculture, v.42, n.2, p.169-176, 1988.

MUALEM, Y. A new model for predisting the hydraulic conductivity of unsaturated porus media. Water Resources Research, v.12, n.3, p.513-522, 1976.

MUCHOW, R. C.; SINCLAIR, T. R. Water deficit effects on maize yields modeled under current and "green hourses" climates. Agronomy Journal, v.83, n.6, p.1052$1059,1991$.

MUZILLI, O. O plantio direto no Brasil. In: FANCELLI, A. L.; TORRADO, P. V.; MACHADO, J. Atualização em plantio direto. Campinas: Fundação Cargill, 1985. $343 p$.

NEILD, R. E. Temperature and rainfall influences on the phenology and yield of grain sorghum and maize: a comparison. Agriculture Meteorology, v.27, p.79-88, 1982. 
NEILD, R. E.; SEELEY, M. W.; RICHMAN, N. H. The computation of agriculturally oriented normals from monthly climatic summaries. Agricultural meteorology, $v$. 19, p.181-197, 1978.

NIMER, E.; BRANDÃO, A. M. P. M. Balanço hídrico e clima da região dos cerrados. Rio de Janeiro: IBGE. Departamento de Recursos Naturais e Estudos Ambientais, 1989. 166p.

NISSEN M., J.; BORTOLAMEOLLI S., G.; DAROCH P., R. Efecto del riego sobre algunas características agronômicas y la produccion de granos de maiz (Zea mays L.) en Valdívia. Agro Sur, v.16, n.1, p.24-31, 1988.

NOLDIM, J. A. Rendimento de grãos, componentes de rendimento e outras características de planta de três cultivares de milho em duas épocas de semeadura. Porto Alegre, 1985. 149p. Dissertação (M.S.) - Universidade Federal do Rio Grande do Sul.

NOLDIN, J. A.; MUNDSTOCK, C. M. Rendimento de grãos e componentes de rendimento de três cultivares de milho em duas épocas de semeadura. Pesquisa Agropecuária Brasileira, v.23, n.6, p.615-620, jun. 1988.

NOVERO, R. P.; O'TOOLE, J. C.; CRUZ, R. T.; GARRITY, D. P. Leaf water potential, crop growth response and microclimate of dryland rice under line source sprinkler irrigation. Agricultural and Forest Meteorology, v.35, n.1, p.71-82, 1985.

NUNEZ, J. G. O. Caracterização das fases fenológicas de três cultivares de milho, utilizando o conceito de graus-dia. Viçosa, 1986. 54p. Dissertação (M.S.) Universidade Federal de Viçosa.

NUSSIO, L.G. A cultura do milho e sorgo para a produção de silagem. In: FANCELLI, L. A. Milho. Piracicaba: FEALQ/ESALQ/USP, 1990. p.58-86.

OLIVEIRA, M. D. X. Comportamento da cultura do milho (Zea mays L.) em diferentes épocas de semeadura nas regiões centro e norte de Mato Grosso do Sul. Lavras, 1990, 90p. Dissertação (M.S.) - Universidade Federal de Lavras.

OLIVEIRA, O. J.; COELHO FLLHO, M. A.; CAMPECHE, L. F. de S. M.; AZEVEDO, B. M.; FOLEGATTI, M. V. Análise comparativa de distribuição do perfil de água em aspersores rotativos de média pressão $(200-400 \mathrm{kPa})$ (compact disc). In: CONGRESO CHILENO DE INGENIERIA AGRICOLA, 2. Chillan, 1997. Resumos. Chillan: Universidad de Concepcion, 1997. p.77. (a) 
OLIVEIRA, O. J.; SOUSA, S. AV, MIRANDA, J. H.; FOLEGATTI, M. V. Simulação da ocorrência de ventos fracos em Cuiabá, Estado de Mato Grosso (compact disc). In: CONGRESO CHILENO DE INGENIERIA AGRICOLA, 2, Chillan, 1997. Resumos. Chillan: Universidad de Concepcion, 1997. p. 80. (6)

OLIVEIRA, S. L. Funções de resposta do milho doce ao uso de irrigação e nitrogênio. Viçosa, 1993. 91p. Tese (Doutorado) - Universidade Federal de Viçosa.

OLIVEIRA, Z. P. Variabilidade espacial dos componentes do balanço hídrico em uma cultura de milho (Zea mays L.). Piracicaba, 1991. 96p. Dissertação (M.S.) - Escola Superior de Agricultura "Luiz de Queiroz", Universidade de São Paulo.

PANDEY,S.; CEBALLOS, H.; KNAPP, E. B.; VARGAS J. D. Variabilidade genética em milho para adaptação a solos ácidos. In: INTERNATIONAL SYMPOSIUM ON ENVIROMENMENTAL STRESS: MAIZE IN PERSPECTIVE, Sete Lagoas, 1995. Proceedings. Sete Lagoas: EMBRAPA/CNPMS/CIMMYT/UNDP, 1995. p. 295319.

PEDRO JÚNIOR, M. J.; SENTELHAS, P. C.; POMMER, C. V.; MARTINS, F. P. Determinação da temperatura-base, graus-dia e índice biometeorológico para a videira "Niágara Rosada". Revista Brasileira de Agrometeorologia. v.2, p.51-56, 1994.

PEREIRA, A. A.; BALDANI, J. L.; BLANA, R. A. G.; NEYRA, C. A. Assimilação e translocação de nitrogênio em relação à produção de grãos e proteínas em milho (Zea mays L.). Revista Brasileira de Ciência do Solo, v.5, p.28-31, 1981.

PEREIRA, A. R. Competição intra-especifica entre plantas cultivadas. O Agronômico, v.41, n. 1, p. 5-11, 1989.

PEREIRA, A. R. Balanço hídrico de um podzolizado de Lins e Marilia cultivado com cafeeiros. Bragantia, v.45, n.2, p.239-247, 1986.

PEREIRA, A.V.; SANTOS, J.A.C. Cultivares de milho precoce e ou planta baixa, para o Estado do Espírito Santo: segunda recomendação. Campo Grande: ENCAPA, 1982. 5p. (Comunicado Técnico, 9).

PEREIRA, R. S. B. Caracteres correlacionados com a produção e suas alterações no melhoramento genético do milho (Zea mays L.). Piracicaba, 1990. 99p. Dissertação (M.S.) - Escola Superior de Agricultura "Luiz de Queiroz", Universidade de São Paulo. 
PIMENTEL, C.; ROSSIELO, R. O. P. Entendimento sobre relações hídricas na cultura do milho. In: SIMPÓSIO INTERNACIONAL SOBRE ESTRESSE AMBIENTAL: O MILHO EM PERSPECTIVA, Sete Lagoas, 1995. Anais. Sete Lagoas: EMBRAPA/CNPMS/CIMMYT/UNDP, 1995. p.131-146.

PFEIFFER, W. H.; SAYRE, K. D.; TRETHOWAN, R. M. An integrated strategy utilizing line source gradients to develop imput responsive triticales adapted to moisture stress $\mathrm{AB}$ : testing using moisture stress gradients generated by line source sprinkler. In: INTERNATIONAL TRITICALE SYMPOSIUM, Passo Fundo, 1990. Proceedings. Passo Fundo: 1990. p. 1-5.

PLAUT, Z. ; REINHOLD, L. The efect of water stress on ${ }^{14} \mathrm{C}$ sucrose transporte in bean plants. Australian Journal Biological Science, v. 18, p.1143-1155, 1965.

POOSTCHI, I.; ROVHANI, I.; RAZMI, K. Influence of levels of spring irrigation and fertility on yield of winter wheat (Triticum aestivum L.) under semi-arid conditions. Agronomy Journal, v.64, n.4, p.438-440, July./Aug. 1972.

PUCKRIDGE, D. W.; O'TOOLE, J. C. Dry matter and grain production of rice, using a line source sprinkler in drought studies. Fields Crops Research, v.3, n.4, p.303319 , Jan. 1981.

RASMUSSEN, V. P.; HANKS, R. J. Spring wheat yield model for limited moisture conditions. Agronomy Journal, v.70, p.940-947, 1978.

REICHARDT, K. Determinação da condutividade hidráulica em condições de campo para a estimativa da drenagem profunda em balanços hídricos. Piracicaba: CENTRO DE ENERGIA NUCLEAR NA AGRICULTURA/USP, 1974. 12p. (Boletim Científico, 15)

REICHARDT, K. Processos de transferência no sistema solo-planta-atmosfera. 2.ed. Campinas: Fundação CARGILL, 1985. 446p.

REICHARDT, K.; BACCHI, O. O.; VILLAGRA, M. M. Estimativa de fluxos de água em solos não saturados. Bragantia, v.52, n.1, p.83-87, 1993.

ROBERTS, B. R. Effects of water stress on the translocation of photosynthetically assimilated carbon-14 in yellow poplar. In: ZIMMERMAN, M. H. The formation of wood forest tress. New York: Academis Press, 1964. 173p.

ROSE, C. W.; STERN, W. R. Determination of withdrawal of water from soil by crop roots as function of depth and time. Australian Journal Soil Research, v.5, p.11$19,1967$. 
RUSSEL, W. K.; STUBER, C. W. Effects of photoperiod and temperature on the duration of vegetative growth in maize. Crop Science, v.23, n.5, p.847-50, Sept./Oct. 1983.

SAKAI, E. Desenvolvimento da cultura do milho em diferentes condições de drenagem subterrânea no vale do Ribeira. Piracicaba, 1996. 102p. Tese (Doutorado) - Escola Superior de Agricultura "Luiz de Queiroz", Universidade de São Paulo.

SEETHARAMA, N.; BIDINGER, F. R.; RAO, K. N.; GIL, K. S.; MULGUND, M. Effect of pattern and severity of moisture deficit stress on stalk rot incidence in sorghum: use of line source irrigation technique, and the effect of time inoculation. Field Crops Research, v.15, p.289-308, Feb. 1987.

SEMINÁRIO SOBRE FISIOLOGIA DA PRODUÇÃO E MANEJO DE ÁGUA E DE NUTRIENTES NA CULTURA DO MILHO DE ALTA PRODUTIVIDADE, Piracicaba, 1996. Milho: fisiologia da produção e manejo da água. Piracicaba: ESALQ/POTAFOS, 1996. 59p.

SENTELHAS, P. C.; NOGUEIRA, S. S. D.; PEDRO JÚNIOR, M. J.; SANTOS, R. R. Temperatura base e graus-dia para cultivares de girassol. Revista Brasileira de Meteorologia, v.2, p.43-49, 1994.

SEPASKHAH, A. R.; LLAMPOUR, S. Effects of soil moisture stress on evapotranspiration partitioning. Agricultural Water Management, v.28, n.4, p.311323, 1995.

SILVA, C. L. Modelagem da precipitação efetiva na cultura do milho. Viçosa, 1993. 82p. Tese (Doutorado) - Universidade Federal de Viçosa.

SILVA, D. D. Efeitos de lâminas de água e doses de nitrogênio na cultura do milho irrigada por aspersão em linha. Viçosa, 1990 . 58p. Dissertação (M.S.) Universidade Federal de Viçosa.

SILVA, J. A. Influência da umidade do solo nas exigências térmicas de três cultivares de milho (Zea mays L.). Viçosa, 1989. 79p. Dissertação (M.S.) - Universidade Federal de Viçosa.

SILVA, M. A. V. Análise de Crescimento, desenvolvimento e eficiência do uso da radiação solar para dois cultivares de Milho. Viçosa, 1995. 63p. Tese (Doutorado) Universidade Federal de Viçosa.

SMITTLE, D. A.; DICKENS, W. L.; STANSELL, J. R. An irrigation scheduling model for snap bean. Journal of the American Society for Horticultural Science, v.115, n.2, p.226-230, 1990. 
SNYDER, F. W.; CARLSON, G. E. Selecting for partitioning of photosynthetic products in crops. Advances in Agronomy, v.37, p.47-72, 1984.

SOBRADO, M. A. Drought responses of tropical corn leaf area and yield components in the field. Maydica, v.35, p.221-226, 1990.

SOBRADO, M. A. Drought responses of tropical corn. Leaf expansion rate and wayer relations under controlled conditions. Maydica, v.35, p.227-234, 1990

SOBRADO, M. A. Drought responses of tropical corn. Water loss and carbon assimilation. Maydica, v.35, p.235-240, 1990.

SOUZA, F. R. S. Estabilidade de cultivares de milho (Zea mays L.) em diferentes épocas e locais de plantio em Minas Gerais. Lavras, 1989. 80p. Dissertação (M.S.) - Universidade Federal de Lavras.

SOUZA, M. L. P.; REICHARDT, K.; LIBARDI, P. L. Perdas de água no solo por drenagem profunda. Energia Nuclear na Agricultura, Piracicaba, v.1, n.2, p.82-93, jul./dez. 1979.

SUTCLIFFE, J. F. As plantas e a água. São Paulo: EPDU/EDUSP, 1980. 126 p.

STEEL, R. G.; TORRIE, J. H. Principles and procedures of statistics. New York: McGraw-Hill, 1980. 633p.

STEWART, D. W.; DWYER, L. M.; CARRIGAN, L. L. Phenological temperature response of maize. Agronomy Journal, v. 90, p. 73-79, Jan./Feb. 1998.

STONE, L. R.; HORTON, M. L.; OLSON, T. C. Water loss from an irrigated sorghum field: I water flux within and below root zone. Agronomy Journal, v.65, p.493-495, 1973.

TARIFA, J. R. Alterações climáticas resultantes da ocupação agrícola no Brasil. Revista do Departamento de Geografia, n.8, p.15-28, 1994.

TOLLENAAR, M. Sink-source relationships during reproductive development in maize: a review. Maydica, v.22, n.2, p.49-75. 1977.

TOLLENAAR, M. Response of dry matter accumulation in maize to temperature: I dry matter partitioning. Crop Science, v.29, p.1239-1246, Sep./Oct. 1989.

TOLLENAAR, M.; DAYNARD, T.B. Leaf senescence in short-season maize híbridos. Canadian Journal of Plant Science, v.58, p. 869-874, July. 1978. 
TOLLENAAR, M.; DAYNARD, T.B.; HUNTER, R. B. Effect of temperature sensitive period leaf number of maize. Crop Science, v.23, p.457-460. 1979.

TOLLENAAR, M.; HUNTER, R. B. A photoperiod and temperature sensitive period for leaf number of maize. Crop Science, v.23, p.457-60, 1983.

TROYER, A.F. Yeld as influenced by maturity and population. Hybrid corn Sorghum Res. Conf. Am. Seed Trade Assoc., n.22, p.91-98, 1968.

TSUNECHIRO, A e ARIAS, E. R. A Perspectivas de rentabilidade do milho "safrinha" nas principais regiões produtoras. In: SEMINÁRIO SOBRE A CULTURA DO MILHO "SAFRINHA", 4., Assis, 1997. Anais. Assis: IAC/CDV, 1997. p.15-20.

TYEM, M. N.; CHIENG, S. T. Irrigation scheduling effects on yield and phosphorus uptake of cowpea. Agricultural Water Management, v.10, n.4, p.343-355, 1985.

TWUMASI-AFRIYIE, S.; HUNTER, R.B. Evaluation of quantitative methods for determining astalk quality in short-season corn genotyps. Canadian Journal of Plant Science, v.62, p.55-60, Jan. 1982.

VIEGAS, G.P. Melhoramento de milho para condições diversas. Campinas: Fundação Cargill, 1989. 44p.

VIEGAS, G. P.; PEETEN, H. Sistemas de produção. In: PATERNIANI, E; VIEGAS, G. P. Melhoramento e produção do milho. Campinas: Fundação Cargill, 1987. v. 2, p. $453-538$.

VILLA NOVA, N. A.; PEDRO JÚNIOR, M. J.; PEREIRA, A. R., OMETTO, J. C. Estimativa de graus-dia acumulados acima de qualquer temperatura base, em função das temperaturas máxima e mínima. Caderno de Ciência da Terra, Instituto de Geografia, Universidade de São Paulo, v.30, 8p. 1972.

VILLAGRA, M. M.; MATSUMOTO, O. M.; BACCHI, O. O. S.; MORAES, S. O; LIBARDI, $P$. L.; REICHARDT, $K$. Tensiometria e variabilidade espacial em terra roxa estruturada. Revista Brasileira de Ciência do Solo, n. 12, p.205-210, 1988.

VILLAGRA, M. M.; BACCHI, O. O. S.; TUON, R. L.; REICHARDT, K. Difficulties of estimating evapotranspiration from the water balance equation, Agricultural and Forest Meteorology, n.72, p.317-325, 1995.

VIRGENS FILHO, J. S.; LEITE, M. L.; RODRIGUES, J. D.. Estudo preliminar de uma metodologia baseada no conceito de graus-dia, para previsão das fases fenológicas de culturas agrícolas. Phyton Buenos Aires, v. 61, n.1-2, p.101-108, 1997. 
VOLPE, C. A. Eficiência no uso da água, resistência estomática e parâmetros aerodinâmicos da cultura de milho (Zea mays L.). Piracicaba, 1986. 204p. Tese (Doutorado) - Escola Superior de agricultura "Luiz de Queiroz", Universidade de São Paulo.

WESTGATE, M. E.; BOYER, J. S. Reproduction at low silk and pollen water potentials in maize. Crop Science, v.26, p.951-956, 1986.

WICKS, Z. W.; CARSON, M. L. Line source irrigation to assess maize inbred line stability. Crop Science, v.27, p.354-356, 1987. 